Nevada

Environmental

Restoration

Project

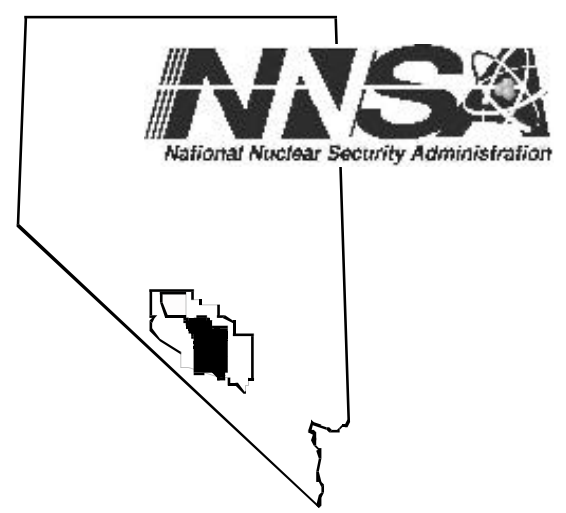

\title{
Completion Report for Well ER-EC-8
}

October 2004

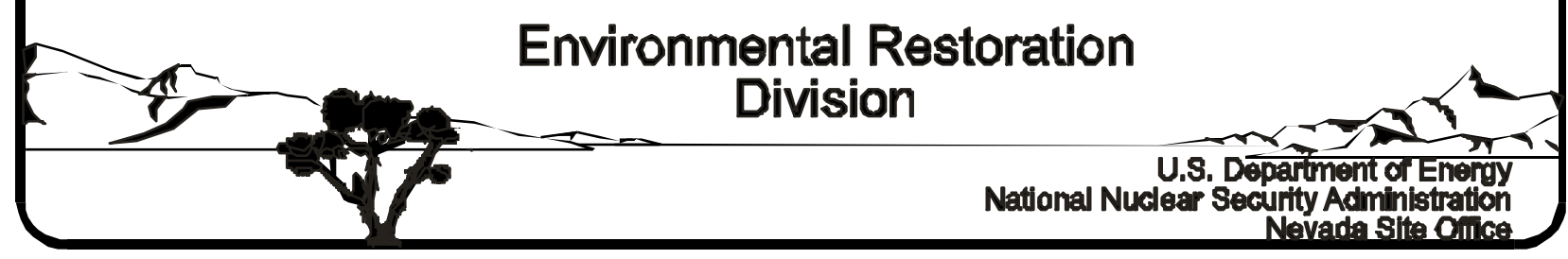




\title{
DISCLAIMER STATEMENT
}

Reference herein to any specific commercial product, process, or service by trade name, trademark, manufacturer, or otherwise, does not necessarily constitute or imply its endorsement, recommendation, or favoring by the U.S. Government or any agency thereof or its contractors or subcontractors.

\section{AVAILABILITY STATEMENT}

Available to the public from:

\author{
U.S. Department of Commerce \\ National Technical Information Service \\ 5285 Port Royal Road \\ Springfield, VA, 22161-0002 \\ Telephone: 800.553 .6847 or 703.605 .6000 \\ Fax: 703.605.6900 \\ E-mail: orders@ntis.gov \\ Online ordering: http://www.ntis.gov/ordering.htm
}

Available electronically at http://www.osti.gov/bridge.

Available for a processing fee to U.S. Department of Energy and its contractors, in paper, from:

U.S. Department of Energy

Office of Scientific and Technical Information

P.O. Box 62

Oak Ridge, TN, 37831-0062

Telephone: 865.576.8401

Fax: 865.576.5728

E-mail: reports@adonis.osti.gov 


\title{
Completion Report for Well ER-EC-8
}

\author{
Prepared for: \\ U. S. Department of Energy \\ National Nuclear Security Administration \\ Nevada Site Office \\ Las Vegas, Nevada
}

Prepared by:

Bechtel Nevada

Geotechnical Sciences

Las Vegas,Nevada

October 2004

This work was supported by the U.S. Department of Energy, National Nuclear Security Administration Nevada Site Office, under Contract No. DE-AC08-96NV11718 
This page intentionally left blank. 


\section{COMPLETION REPORT FOR WELL ER-EC-8}

Approved by; Rolent Mn. Bungester \&. fowilliam R. Wilborn, Acting Project Manager, Underground Test Area Project

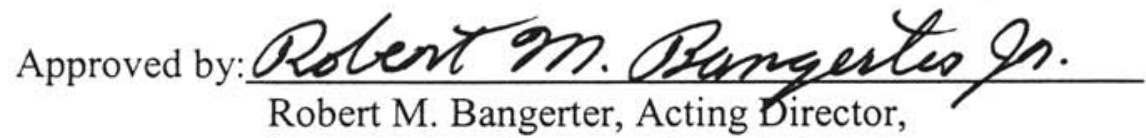
Environmental Restoration Division
Date: $12 / 8 / 04$

Date $12 / 8 / 04$ 
This page intentionally left blank. 


\title{
Completion Report for Well ER-EC-8 \\ DOE/NV/11718--435
}

\begin{abstract}
Well ER-EC-8 was drilled for the U.S. Department of Energy, National Nuclear Security Administration Nevada Site Office in support of the Nevada Environmental Restoration Project at the Nevada Test Site, Nye County, Nevada. This well was drilled in the summer of 1999 as part of the U.S. Department of Energy's hydrogeologic investigation program in the Western Pahute Mesa Oasis Valley region just west of the Nevada Test Site. A 44.5-centimeter surface hole was drilled and cased off to a depth of 129.8 meters below the surface. The hole diameter was then decreased to 31.1 centimeters for drilling to a total depth of 609.6 meters.
\end{abstract}

One completion string with three isolated slotted intervals was installed in the well. A preliminary composite, static water level was measured at the depth of 98.4 meters, 24 days after installation of the completion string.

Detailed lithologic descriptions with stratigraphic assignments are included in the report. These are based on evaluation of composite drill cuttings collected every 3 meters, and 20 sidewall samples taken at various depths below 157.9 meters, supplemented by geophysical log data and results of detailed chemical and mineralogical studies of rock samples. Drilling began in Tertiary-age tuff of the Thirsty Canyon Group, and penetrated tuffs of the Beatty Wash Formation, tuff of Buttonhook Wash, and the upper portion of the Ammonia Tanks Tuff. The geologic interpretation of data from this well helps define the location of the western margin of the Timber Mountain caldera complex in the southwestern Nevada volcanic field. Geologic and hydrologic data from the well will aid in development of models to predict groundwater flow and contaminant migration within and near the Nevada Test Site. 
This page intentionally left blank. 


\section{Table of Contents}

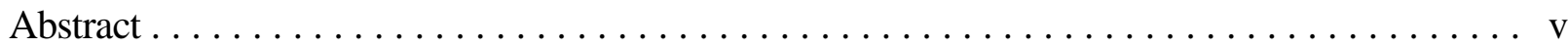

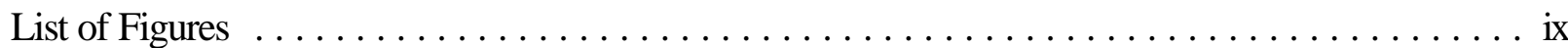

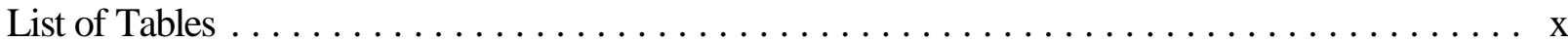

List of Acronyms and Abbreviations $\ldots \ldots \ldots \ldots \ldots \ldots \ldots \ldots \ldots \ldots \ldots \ldots \ldots \ldots \ldots \ldots$

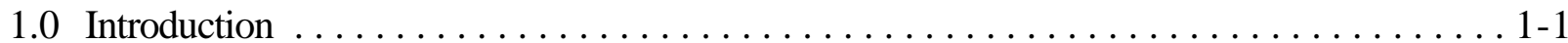

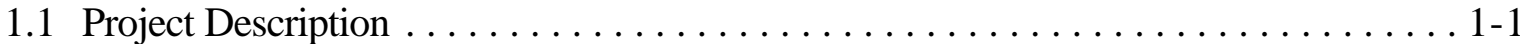

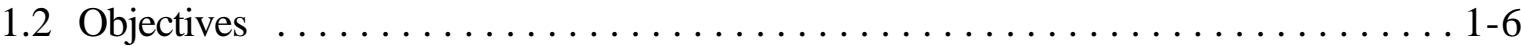

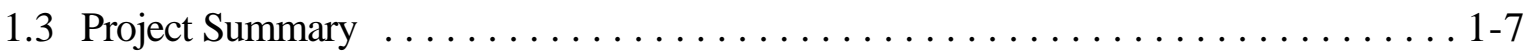

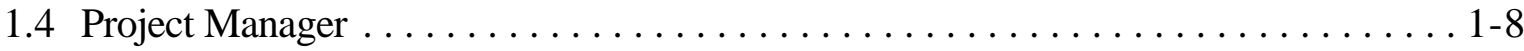

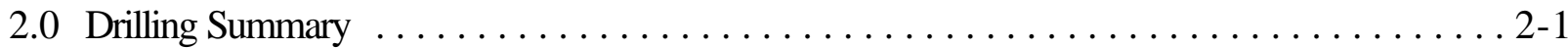

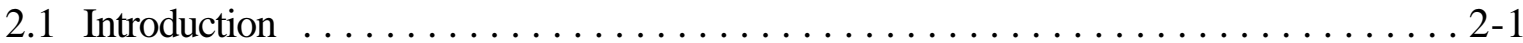

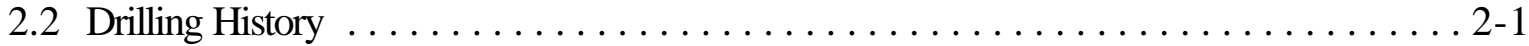

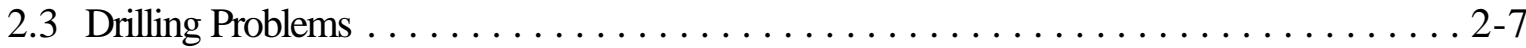

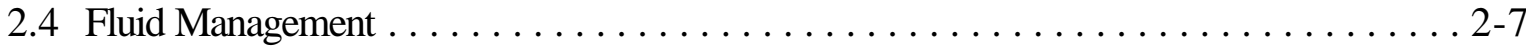

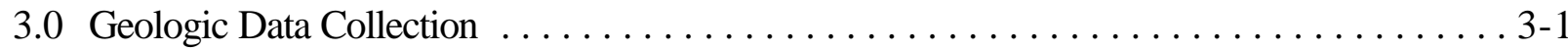

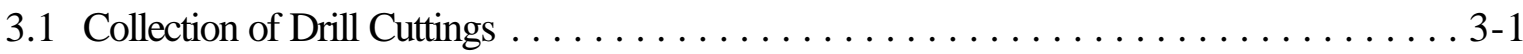

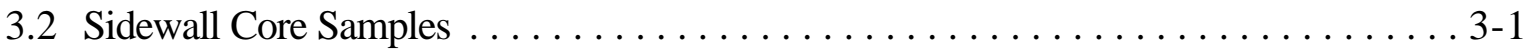

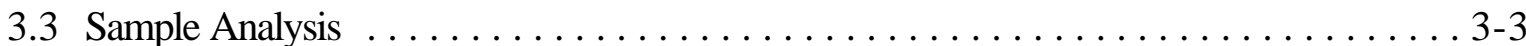

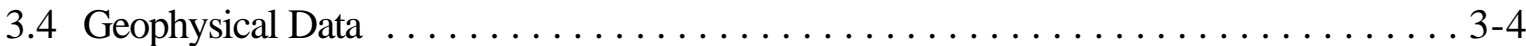

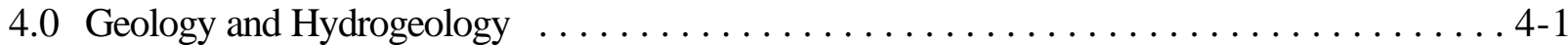

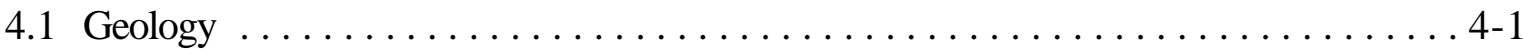

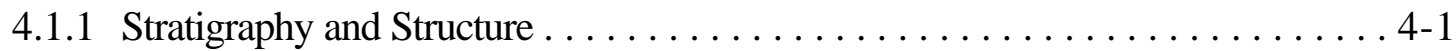

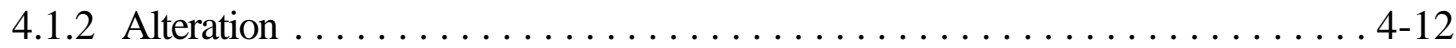

4.2 Predicted Versus Actual Geology $\ldots \ldots \ldots \ldots \ldots \ldots \ldots \ldots \ldots \ldots \ldots$. . . . . . . . . . . . . .

4.3 Hydrogeology . . . . . . . . . . . . . . . . . . . . . . . . . . . . 4-14 


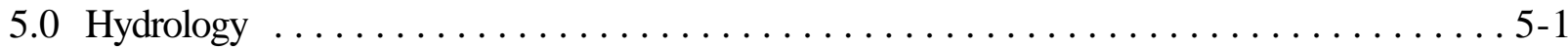

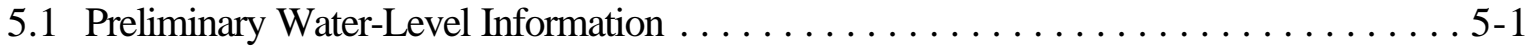

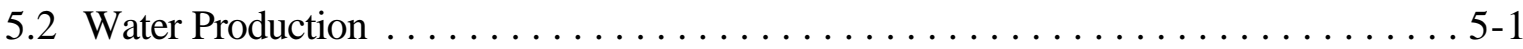

5.3 Preliminary Thermal Flow Meter Data $\ldots \ldots \ldots \ldots \ldots \ldots \ldots \ldots \ldots \ldots \ldots \ldots \ldots \ldots \ldots \ldots \ldots \ldots$

5.4 Preliminary Groundwater Characterization Samples $\ldots \ldots \ldots \ldots \ldots \ldots \ldots \ldots .2$

6.0 Precompletion and Open-Hole Development ............................ 6-1

7.0 Well Completion ............................................ $7-1$

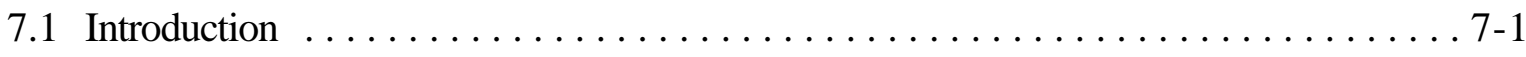

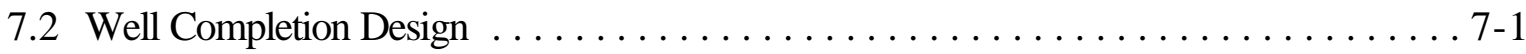

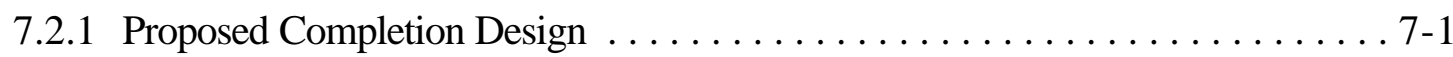

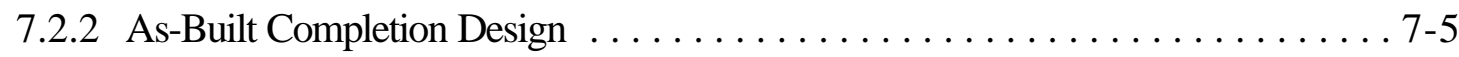

7.2.3 Rationale for Differences between Actual and Proposed Well Design . . . . . . . . 7-6

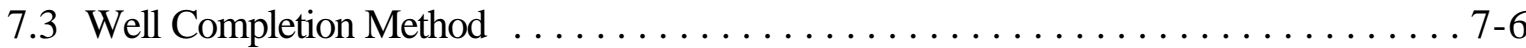

8.0 Actual versus Planned Costs and Scheduling $\ldots \ldots \ldots \ldots \ldots \ldots \ldots \ldots \ldots \ldots \ldots \ldots \ldots \ldots$

9.0 Summary, Recommendations, and Lessons Learned . . . . . . . . . . . . . . . . . 9-1

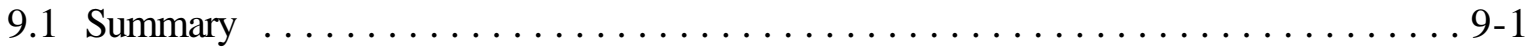

9.2 Recommendations $\ldots \ldots \ldots \ldots \ldots \ldots \ldots \ldots \ldots \ldots \ldots \ldots \ldots \ldots \ldots \ldots \ldots \ldots \ldots \ldots \ldots, 2$

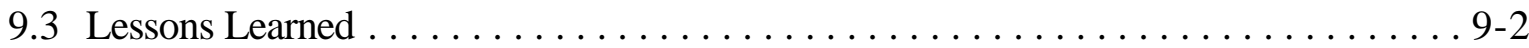

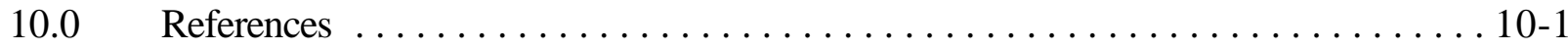

Appendix A - Drilling Data

A-1 Drilling Parameter Log for Well ER-EC-8

A-2 Casing Data for Well ER-EC-8

A-3 Well ER-EC-8 Drilling Fluids and Cement Composition

Appendix B - Well ER-EC-8 Fluid Management Data

Appendix C - Detailed Lithologic Log for Well ER-EC-8

Appendix D - Geophysical Logs Run in Well ER-EC-8

Distribution List 


\section{List of Figures}

Number

Title

Page

1-1 Reference Map Showing Location of Well ER-EC-8 $\ldots \ldots \ldots \ldots \ldots \ldots \ldots \ldots \ldots$ 1-3

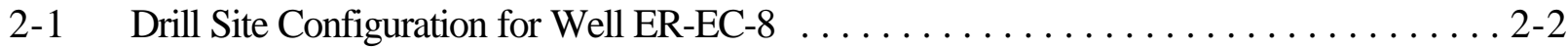

2-2 Well ER-EC-8 Drilling and Completion History $\ldots \ldots \ldots \ldots \ldots \ldots \ldots \ldots \ldots \ldots \ldots \ldots .2-3$

4-1 Map of Western Pahute Mesa - Oasis Valley Area Showing Theorized Locations of Caldera Boundaries ..................................4-3

4-2 Surface Geologic Map of the Well ER-EC-8 Site . . . . . . . . . . . . . . . . . 4-5

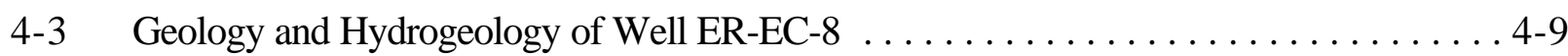

4-4 Geologic Cross Section A-A' Through Well ER-EC-8 . . . . . . . . . . . . . . . . 4-11

4-5 Predicted and Actual Stratigraphy at Well ER-EC-8 . . . . . . . . . . . . . . . . 4-13

4-6 Hydrogeologic Cross Section B-B' Through Well ER-EC-8 . . . . . . . . . . . . . . . 4-15

7-1 As-Built Completion Schematic for Well ER-EC-8 . . . . . . . . . . . . . . . . 7-2

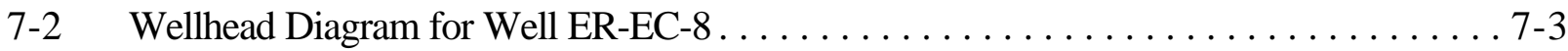

8-1 Planned versus Actual Construction Progress for Well ER-EC-8 . . . . . . . . . . . . 8 8-2

8-2 Planned versus Actual Cost for Constructing Well ER-EC-8 . . . . . . . . . . . . 8-3 


\section{List of Tables}

Number

Title

Page

1-1 Well ER-EC-8 Site Data Summary .......................... 1-5

2-1 Abridged Drill Hole Statistics for Well ER-EC-8 . . . . . . . . . . . . . . . . . . . . 2 2-5

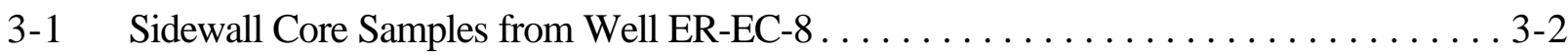

3-2 Rock Samples from Well ER-EC-8 Submitted for Analysis . . . . . . . . . . . . . 3-3

3-3 Well ER-EC-8 Geophysical Log Summary ........................ 3-5

7-1 Well ER-EC-8 Completion String Construction Summary . . . . . . . . . . . . . . . . 7-4

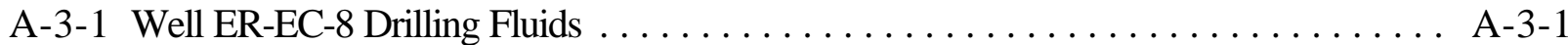

A-3-2 Well ER-EC-8 Cement Composition $\ldots \ldots \ldots \ldots \ldots \ldots \ldots \ldots \ldots \ldots \ldots$ A-3-1

D-1 Well ER-EC-8 Geophysical Logs Presented ....................... D-1 


\section{List of Acronyms and Abbreviations}

\begin{tabular}{|c|c|}
\hline $\mathrm{BHA}$ & bottom-hole assembly \\
\hline $\mathrm{BN}$ & Bechtel Nevada \\
\hline $\mathrm{C}$ & Celsius \\
\hline $\mathrm{cm}$ & centimeter(s) \\
\hline DOE & U.S. Department of Energy \\
\hline $\mathrm{DOE} / \mathrm{NV}$ & U.S. Department of Energy, Nevada Operations Office \\
\hline DRI & Desert Research Institute \\
\hline $\mathrm{EC}$ & Electrical Conductivity \\
\hline $\mathrm{F}$ & Fahrenheit \\
\hline FMP & Fluid Management Plan \\
\hline $\mathrm{ft}$ & foot (feet) \\
\hline gpm & gallons per minute \\
\hline in. & inch(es) \\
\hline IT & IT Corporation \\
\hline $\mathrm{km}$ & kilometer(s) \\
\hline lpm & liters per minute \\
\hline LANL & Los Alamos National Laboratory \\
\hline $\mathrm{LiBr}$ & lithium bromide \\
\hline $\mathrm{m}$ & meter(s) \\
\hline Ma & million years ago \\
\hline mi & mile(s) \\
\hline NAD & North American Datum \\
\hline NNSA/NSO & National Nuclear Security Administration Nevada Site Office \\
\hline NTS & Nevada Test Site \\
\hline $\mathrm{TD}$ & total depth \\
\hline TFM & Thermal Flow Meter \\
\hline TMCC & Timber Mountain caldera complex \\
\hline UDI & United Drilling, Inc. \\
\hline UGTA & Underground Test Area \\
\hline USGS & United States Geological Survey \\
\hline WPM-OV & Western Pahute Mesa - Oasis Valley \\
\hline
\end{tabular}


This page intentionally left blank. 


\subsection{Introduction}

\subsection{Project Description}

Well ER-EC-8 was drilled for the U.S. Department of Energy (DOE), National Nuclear Security Administration Nevada Site Office (NNSA/NSO; formerly Nevada Operations Office, DOE/NV) in support of the Nevada Environmental Restoration Project at the Nevada Test Site (NTS), Nye County, Nevada. Well ER-EC-8 is the sixth in a series of wells drilled as part of the hydrogeologic investigation well program in the Western Pahute Mesa - Oasis Valley (WPM-OV) region of Nye County, Nevada. This program is part of the NNSA/NSO Environmental Restoration Division's Underground Test Area (UGTA) project at the NTS. The goals of the UGTA project include evaluating the nature and extent of contamination in groundwater due to underground nuclear testing, and establishing a long-term groundwater monitoring network. As part of the UGTA project, scientists are developing computer models to predict groundwater flow and contaminant migration within and near the NTS. To build and test these models, it is necessary to collect geologic, geophysical, and hydrologic data from new and existing wells to define groundwater migration pathways, migration rates, and quality.

The goal of the WPM-OV program is to collect subsurface geologic and hydrologic data in a large, insufficiently characterized area down-gradient from Pahute Mesa where underground nuclear tests were conducted and up-gradient from groundwater discharge and withdrawal sites in Oasis Valley northeast of Beatty, Nevada (Figure 1-1). Data from these wells will allow for more accurate modeling of groundwater flow and radionuclide migration in the region. Some of the wells may also function as long-term monitoring wells.

Well ER-EC-8 is located within the Nellis Air Force Range complex, approximately 19 kilometers $(\mathrm{km})$ (12.0 miles [mi]) southwest of the Area 20 underground nuclear test area (Figure 1-1), just east of a geophysically inferred north-northeast striking structure (Thirsty Canyon lineament). The elevation of the dirt-fill drill pad at the wellhead is 1,320.9 meters (m) $(4,333.5$ feet [ft]) above mean sea level. The Nevada State Planar coordinates (North American Datum [NAD] 1983) at the wellhead are North (N) 6,261,034.5 m and East (E) 503,065.7 m (N 20,541,410.7 and E 1,650,474.7 ft). Additional site data are listed in Table 1-1.

IT Corporation (IT) was the principal environmental contractor for the project, and IT personnel collected geologic and hydrologic data during drilling. The drilling company was United Drilling, 
This page intentionally left blank. 


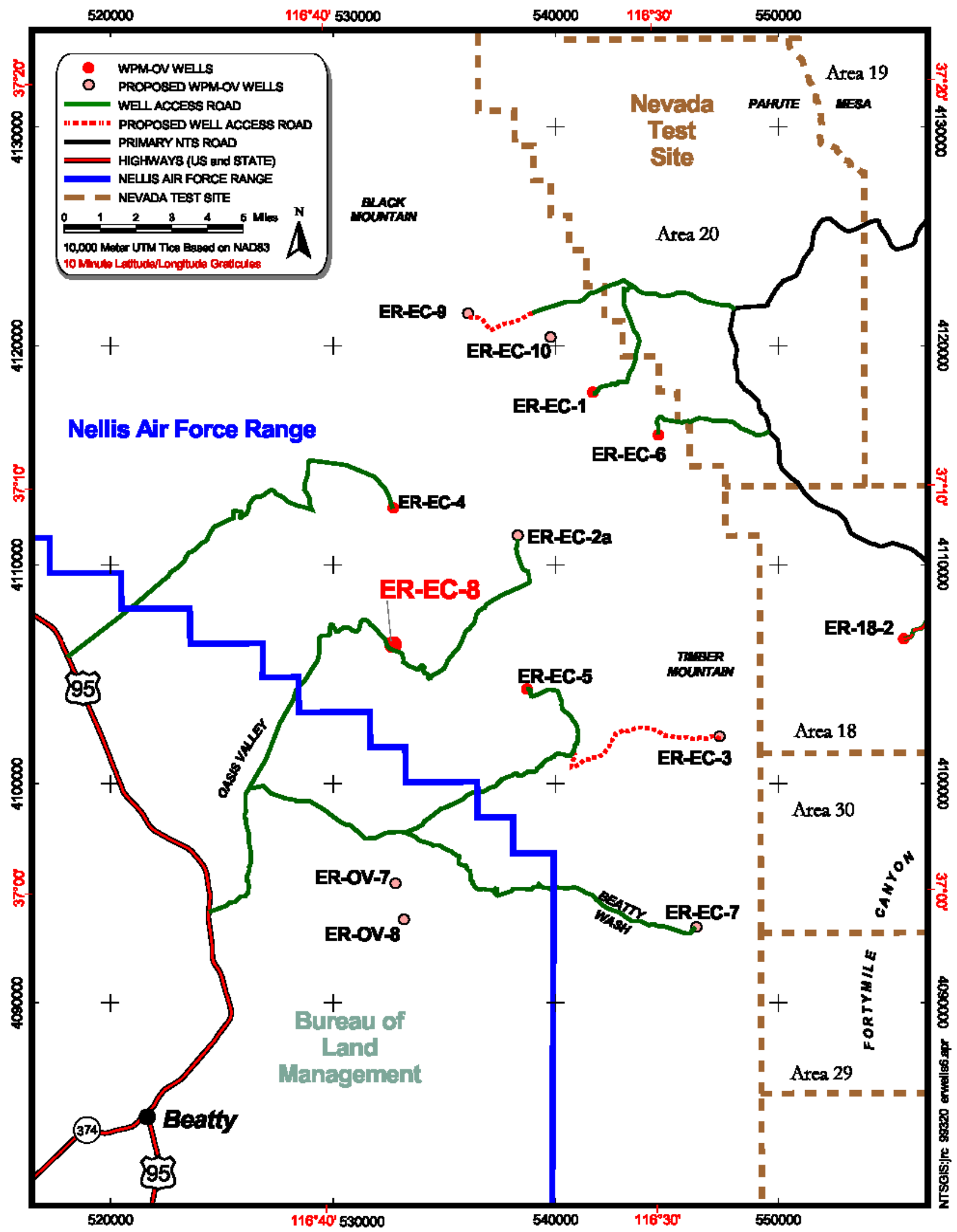

Figure 1-1

Reference Map Showing Location of Well ER-EC-8

(Proposed wells not drilled at time Well ER-EC-8 was drilled.) 
This page intentionally left blank. 
Table 1-1

Well ER-EC-8 Site Data Summary

\begin{tabular}{|c|c|}
\hline Well Designation & ER-EC-8 \\
\hline Site Coordinates ${ }^{a}$ & 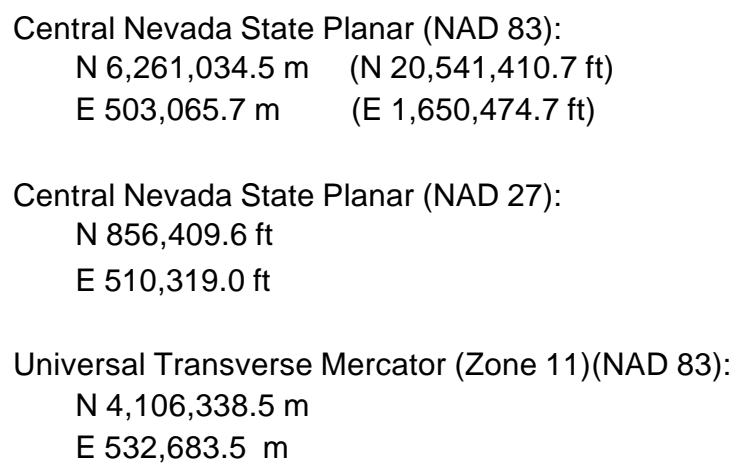 \\
\hline Surface Elevation ${ }^{b}$ & $1,320.9 \mathrm{~m}(4,333.5 \mathrm{ft})$ \\
\hline Drilled Depth & $609.6 \mathrm{~m}(2,000 \mathrm{ft})$ \\
\hline Fluid-Level Depth ${ }^{c}$ & $98.4 \mathrm{~m}(322.7 \mathrm{ft})$ \\
\hline Fluid-Level Elevation & $1,222.5 \mathrm{~m}(4,010.8 \mathrm{ft})$ \\
\hline
\end{tabular}

a Measured by BN Survey.

b Measured by BN Survey. Elevation at top of drill pad. 1929 National Geodetic Vertical Datum.

c Measured by IT on August 19, 1999, 24 days after completion string was stemmed (IT, 1999).

Incorporated (UDI), a subcontractor to Bechtel Nevada (BN). Site supervision, engineering, construction, inspection, and geologic support were provided by BN. The roles and responsibilities of these and other contractors involved in the project are described in Contract Number DE-RP-08-95NV11808 and in BN Drilling Work Plan Number D-007-001.99 (BN, 1999b). The UGTA Technical Working Group, a committee of scientists and engineers from various agencies and organizations, provided additional technical advice during drilling, design, and construction of the well. See FY99 Western Pahute Mesa-Oasis Valley Hydrogeologic Investigation Wells Drilling and Completion Criteria (IT, 1998) for descriptions of the general plan and goals of the WPM-OV project, as well as specific goals for each planned well.

General guidelines for managing fluids used and generated during drilling, completion, and testing of UGTA wells are provided in the UGTA Fluid Management Plan (FMP) (DOE, 1996a), an attachment to the UGTA Waste Management Plan (DOE, 1996b). Estimates of fluid and cuttings production for the WPM-OV holes are given in Appendix $\mathrm{N}$ of the drilling and completion criteria 
document for the WPM-OV project (IT, 1998), along with sampling requirements and contingency plans for management of any hazardous waste produced. All activities were conducted according to the Nevada Environmental Restoration Project Health and Safety Plan (DOE, 1998), and the SiteSpecific Health and Safety Plan for WPM-OV Investigation Wells (BN, 1999a).

This report presents construction data and summarizes scientific data gathered during drilling and installation of the completion string. Some of the information in this report is preliminary and unprocessed, but is being released with the drilling and completion data for convenient reference. A preliminary well data report prepared by IT (IT, 1999) contains additional information on fluid management, waste management, and environmental compliance. Information on well development, aquifer testing, and groundwater analytical sampling will be disseminated after any such work is performed.

\subsection{Objectives}

The primary purpose of Well ER-EC-8 is to provide information about hydrostratigraphic units, geologic structures, and bulk hydraulic properties in this part of the WPM-OV area. Well-specific scientific objectives, as discussed in Appendix H of the drilling criteria document (IT, 1998), include the following:

! Determine and evaluate groundwater levels to assist in characterization of groundwater flow from Pahute Mesa to Oasis Valley.

! Further characterize a geophysically inferred, north-northeast striking structure informally known as the Thirsty Canyon lineament (Grauch et al., 1997).

Some of these objectives will not be met until additional work, outside the scope of this report, is completed, including installing a pump and conducting hydraulic testing, and analyzing geology and hydrology data from this and other planned wells in the WPM-OV area.

\subsection{Project Summary}

This section summarizes Well ER-EC-8 construction operations; the details are provided in sections 2 through 8 of this report.

The surface conductor hole was constructed by augering a 91.4-centimeter $(\mathrm{cm})$ (36-inch [in.]) hole

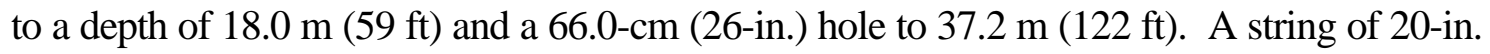
conductor casing was set at $36.7 \mathrm{~m}(120.5 \mathrm{ft})$ below ground level and cemented on June 2, 1999. 
Drilling of the main hole with a 171/2-in. rotary bit, using air-foam and polymer in conventional circulation, began on July 14, 1999. A suitable depth to set casing was reached at $130.5 \mathrm{~m}$ (428 ft), and $13 \mathrm{~d}$-in. surface casing was landed at $129.8 \mathrm{~m}$ (426 ft) on July 16, 1999, approximately $31.5 \mathrm{~m}$ $(103 \mathrm{ft})$ below the static water level. Drilling continued with a 12/4-in. bit to a total depth (TD) of $609.6 \mathrm{~m}(2,000 \mathrm{ft})$, which was reached on July 21, 1999.

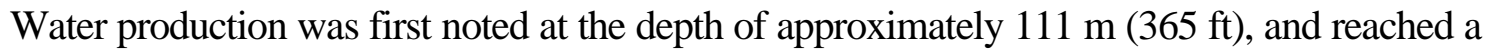
maximum of over 5,487 liters per minute (lpm) (1,450 gallons per minute [gpm]) near the bottom of the hole. Twenty-four days after installation of the completion string, the fluid level was tagged by IT at the depth of $98.4 \mathrm{~m}(322.7 \mathrm{ft})$. No radionuclides above background levels were encountered during drilling of Well ER-EC-8.

Composite drill cuttings were collected every $3.0 \mathrm{~m}(10 \mathrm{ft})$ from $36.6 \mathrm{~m}(120 \mathrm{ft})$ to TD, and 20 sidewall core samples were taken at various depths below $157.9 \mathrm{~m}(518 \mathrm{ft})$. Open-hole geophysical logging of the well below the surface casing was conducted to help verify the geology and characterize the hydrologic properties of the rocks; some logs also aided in the construction of the well by indicating borehole volume and condition and cement location. The well penetrated Tertiary-age lava and tuff of the Thirsty Canyon Group, Beatty Wash Formation, tuff of Buttonhook Wash, and mafic-poor Ammonia Tanks Tuff.

A single completion string was installed in Well ER-EC-8 on July 24, 1999. Stainless steel, 51/2-in. production casing was landed at $594.4 \mathrm{~m}(1,950.0 \mathrm{ft})$. The bull-nosed string has three slotted intervals, at 511.0 to $581.5 \mathrm{~m}$ (1,676.5 to $1,907.8 \mathrm{ft}), 441.0$ to $459.3 \mathrm{~m}$ (1,446.7 to 1,506.9 ft), and 201.8 to $299.8 \mathrm{~m}$ (682.6 to $983.7 \mathrm{ft})$. Internally epoxy-coated, $7 \mathrm{e}$-in. carbon-steel casing extends (via a crossover sub) from the top of the 51/2-in. casing at $189.7 \mathrm{~m}(622.4 \mathrm{ft})$ to the ground surface. The completion string was gravel-packed across the slotted intervals and the remaining annular space was filled with gravel, sand, and cement to $21.3 \mathrm{~m}$ (70 ft) on July 26, 1999. No pump was installed at the time of completion. 


\subsection{Project Manager}

Inquiries concerning Well ER-EC-8 should be directed to the UGTA Project Manager at:

U.S. Department of Energy

National Nuclear Security Administration

Nevada Site Office

Environmental Restoration Division

Post Office Box 98518

Las Vegas, Nevada 89193-8518 


\subsection{Drilling Summary}

This section contains detailed descriptions of the drilling process and fluid management issues.

\subsection{Introduction}

The general drilling requirements for all WPM-OV wells were provided in FY99 Western Pahute Mesa-Oasis Valley Hydrogeologic Investigation Wells Drilling and Completion Criteria (IT, 1998). Specific requirements for Well ER-EC-8 were outlined in Drilling Work Plan Number D-007-001.99 (BN, 1999b). The following information was compiled primarily from BN daily drilling reports. Figure 2-1 shows the layout of the drill site. Figure 2-2 is a chart of the drilling and completion history for Well ER-EC-8. A summary of drilling statistics for the well is given in Table 2-1.

\subsection{Drilling History}

Field operations began at Well ER-EC-8 when a BN crew began augering a 66.0-cm (26-in.) conductor hole to $37.2 \mathrm{~m}$ (122 ft). The hole was opened with a 91.4-cm (36-in. auger) to $18.0 \mathrm{~m}$ (59 ft). A string of 20-in. casing was set at $36.7 \mathrm{~m}(120.5 \mathrm{ft})$ and cemented into place on June 1,1999 . Cementing of the casing annulus with a " $75 / 25$ " mix of cement and sand to the surface was completed on June 2, 1999. The site was inactive until the construction of Well ER-EC-5 was completed, and UDI equipment started arriving on July 12, 1999. The UDI crews rigged up the Wilson Mogul 42B rig on July 12 through 14, 1999, and tagged cement inside the conductor casing at the depth of $34.7 \mathrm{~m}(114 \mathrm{ft})$.

Drilling of the main hole with a 171/2-in. button bit began on July 14, 1999, using an air-water-foam mix ("air-foam") with a polymer additive in conventional (direct) circulation. Drilling progressed rapidly, and the first water production was noted by IT personnel at a depth of approximately $111 \mathrm{~m}(365 \mathrm{ft})$.

As a precaution against sloughing of the upper section of unsaturated volcanic rocks, it was decided to install surface casing when a competent formation for supporting the casing was reached. The decision was made to stop and set casing on July 15, 1999, at a depth of $130.5 \mathrm{~m}$ (428 ft). At this depth the hole was producing water at a rate of approximately $303 \mathrm{lpm}(80 \mathrm{gpm})$. The drillers circulated fluid to clean and condition the hole, pulled the drill string off the bottom, and waited 


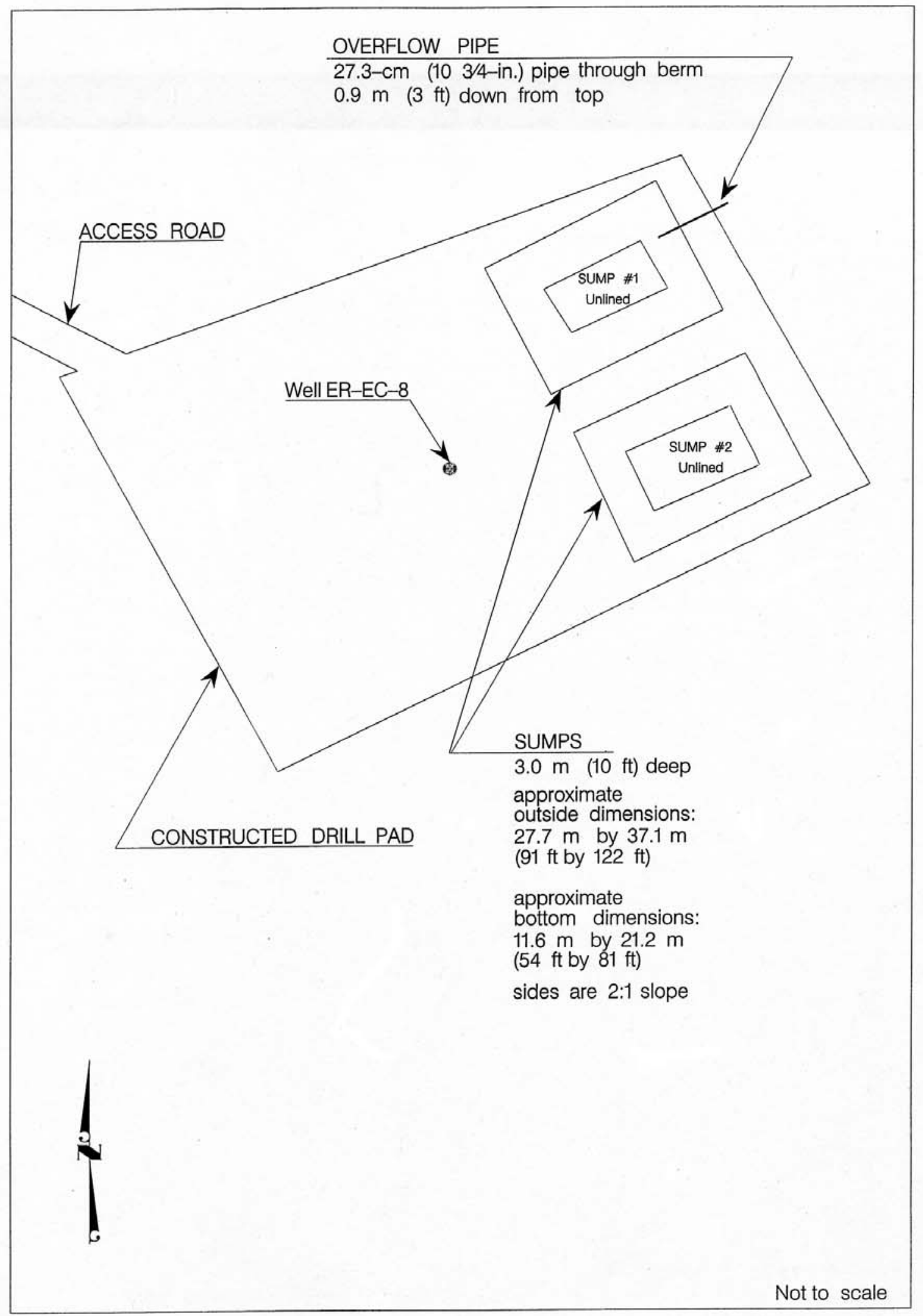

Figure 2-1

Drill Site Configuration for Well ER-EC-8 


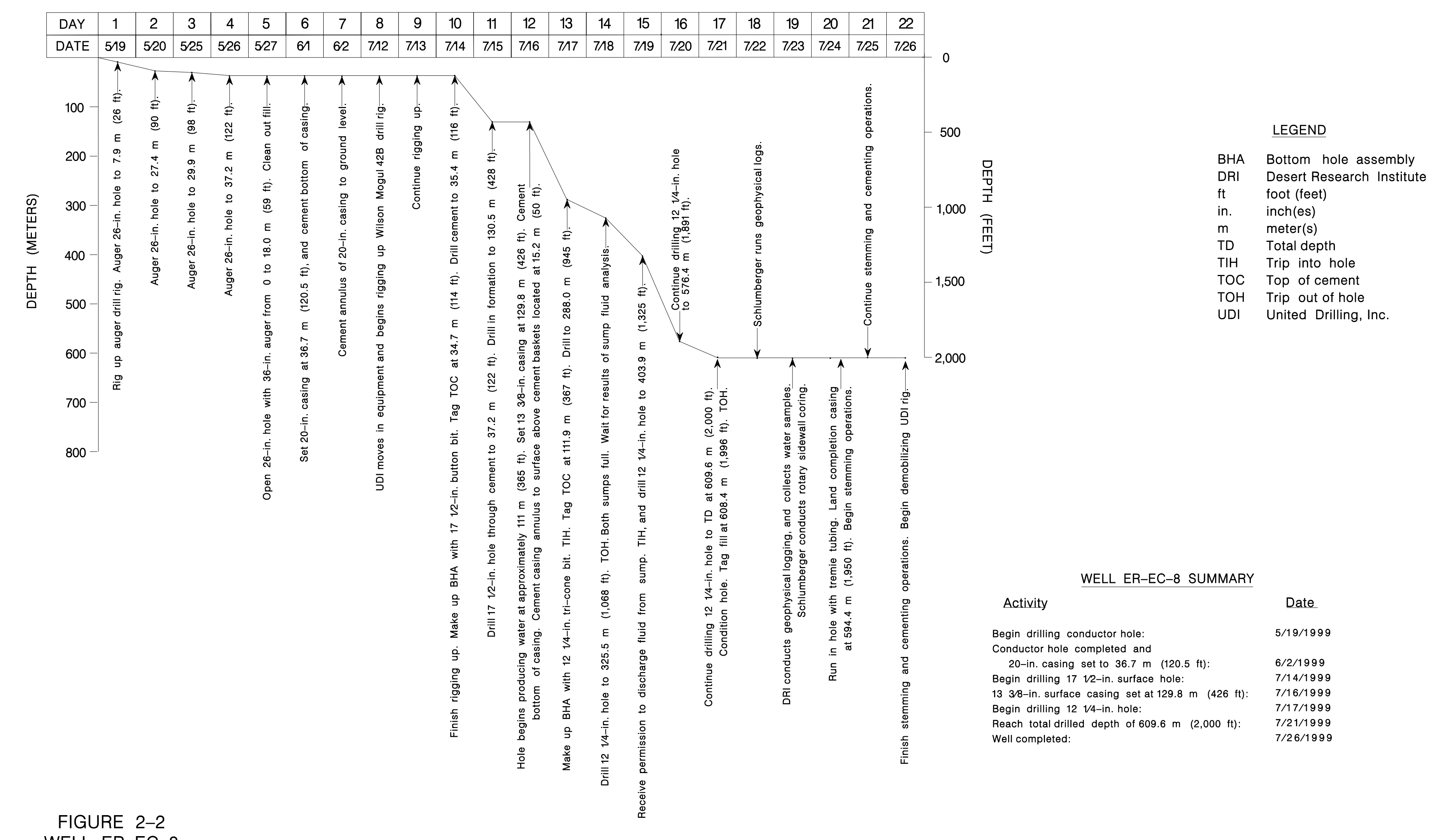

WELL ER-EC-8

DRILLING AND COMPLETION

HISTORY 
This page intentionally left blank. 
Table 2-1

Abridged Drill Hole Statistics for Well ER-EC-8

\begin{tabular}{|c|c|c|c|}
\hline $\begin{array}{l}\text { LOCATION DATA: } \\
\text { Coordinates: } \\
\text { Surface Elevation }{ }^{\mathrm{a}} \text { : }\end{array}$ & $\begin{array}{l}\text { Central Nevada State Planar: } \\
\text { Universal Transverse Mercator: } \\
1,320.9 \mathrm{~m}(4,333.5 \mathrm{ft})\end{array}$ & $\begin{array}{l}\text { NAD 83: } N 6,2 \\
\text { NAD 27: } N 856 \\
\text { NAD 83: } \quad \text { N } 4,1\end{array}$ & $\begin{array}{l}034.5 \mathrm{~m} \quad \mathrm{E} 503,065.7 \mathrm{~m} \\
09.6 \mathrm{ft} \quad \mathrm{E} 510,319.0 \mathrm{ft} \\
, 338.5 \mathrm{~m} \quad \mathrm{E} \mathrm{532,683.5} \mathrm{m}\end{array}$ \\
\hline \multicolumn{4}{|l|}{ DRILLING DATA: } \\
\hline Spud Date: & \multicolumn{3}{|c|}{ 7/15/1999 (main hole, drilled with Wilson Mogul 42B rig) } \\
\hline $\begin{array}{l}\text { Total Depth (TD): } \\
\text { Date TD Reached: }\end{array}$ & \multicolumn{3}{|l|}{$\begin{array}{l}609.6 \mathrm{~m}(2,000 \mathrm{ft}) \\
7 / 21 / 1999\end{array}$} \\
\hline $\begin{array}{l}\text { Date Well Completed }{ }^{\mathrm{b}} \text { : } \\
\text { Hole Diameter: }\end{array}$ & \multirow{2}{*}{\multicolumn{3}{|c|}{$\begin{array}{l}7 / 26 / 1999 \\
91.4 \mathrm{~cm}(36 \mathrm{in} .) \text { from surface to } 18.0 \mathrm{~m}(59 \mathrm{ft} .) ; 66.0 \mathrm{~cm}(26.0 \mathrm{in} .) \text { from } 18.0 \text { to } \\
37.2 \mathrm{~m}(59 \text { to } 122 \mathrm{ft}) ; 44.5 \mathrm{~cm}(17.5 \mathrm{in} .) \text { from } 37.2 \text { to } 130.5 \mathrm{~m}(122 \mathrm{to} 428 \mathrm{ft}) ; \\
31.1 \mathrm{~cm}(12.25 \mathrm{in} .) \text { from } 130.5 \mathrm{~m}(428 \mathrm{ft}) \text { to TD of } 609.6 \mathrm{~m}(2,000 \mathrm{ft}) .\end{array}$}} \\
\hline & & & \\
\hline Drilling Techniques: & \multicolumn{3}{|c|}{$\begin{array}{l}\text { Dry-hole auger from surface to } 37.2 \mathrm{~m} \text { (122 ft.); rotary drilling using air-foam } \\
\text { and polymer in direct circulation with } 171 / 2 \text {-in. bit from } 37.2 \text { to } 130.5 \mathrm{~m} \text { (122 to } \\
428 \mathrm{ft}) \text {, and with a } 12^{1 / 4} \text {-in. bit to the TD of } 609.6 \mathrm{~m}(2,000 \mathrm{ft}) \text {. }\end{array}$} \\
\hline CASING DATA: & \multicolumn{3}{|c|}{$\begin{array}{l}\text { 20-in. conductor casing, surface to } 36.7 \mathrm{~m}(120.5 \mathrm{ft}) ; 13 \mathrm{~d} \text {-in. surface casing, } \\
\text { surface to } 129.8 \mathrm{~m}(426 \mathrm{ft}) \text {. }\end{array}$} \\
\hline \multicolumn{4}{|c|}{$\begin{array}{l}\text { WELL COMPLETION DATA: } \\
\text { The completion string consists of } 7 \mathrm{e} \text {-in. carbon-steel casing with an internal epoxy coating, connected to } \\
51 / 2 \text {-in. stainless-steel casing via an internally coated carbon-steel crossover sub. The carbon-steel } \\
\text { casing extends through the unsaturated zone to the depth of } 189.7 \mathrm{~m}(622.4 \mathrm{ft}) \text {, approximately } 91.4 \mathrm{~m} \\
\text { ( } 300 \mathrm{ft} \text { ) into the top of the saturated zone. The } 14.0-\mathrm{cm} \text { ( } 5.5 \text {-in.) outside-diameter casing has a } 12.83-\mathrm{cm} \\
\text { (5.05-in.) inside diameter, is bull-nosed, and has three slotted intervals (listed below). Detailed data for } \\
\text { the completion intervals are provided in Section } 7 \text { of this report. }\end{array}$} \\
\hline Total Depth: & \multicolumn{3}{|l|}{$594.4 \mathrm{~m}(1,950.0 \mathrm{ft})$} \\
\hline Depth of Slotted Sections: & $\begin{array}{l}208.1 \text { to } 299.8 \mathrm{~m} \\
(682.6 \text { to } 983.7 \mathrm{ft})\end{array}$ & $\begin{array}{l}\text { to } 459.3 \mathrm{~m} \\
6.7 \text { to } 1,506.9 \mathrm{ft})\end{array}$ & $\begin{array}{l}511.0 \text { to } 581.5 \mathrm{~m} \\
(1,676.5 \text { to } 1,907.8 \mathrm{ft})\end{array}$ \\
\hline Depth of Sand Packs: & $\begin{array}{l}192.6 \text { to } 201.8 \mathrm{~m} \\
(632 \text { to } 662 \mathrm{ft})\end{array}$ & $\begin{array}{l}\text { to } 453.3 \mathrm{~m} \\
8 \text { to } 1,428 \mathrm{ft} \text { ) }\end{array}$ & $\begin{array}{l}495.6 \text { to } 506.0 \mathrm{~m} \\
(1,626 \text { to } 1,660 \mathrm{ft})\end{array}$ \\
\hline Depth of Gravel Packs ${ }^{c}$ : & $\begin{array}{l}201.8 \text { to } 320.0 \mathrm{~m} \\
(662 \text { to } 1,050 \mathrm{ft})\end{array}$ & $\begin{array}{l}\text { to } 474.9 \mathrm{~m} \\
8 \text { to } 1,558 \mathrm{ft})\end{array}$ & $\begin{array}{l}506.0 \text { to } 606.6 \mathrm{~m} \\
(1,660 \text { to } 1,990 \mathrm{ft})\end{array}$ \\
\hline Depth of Pump: & \multicolumn{3}{|c|}{ None installed at time of completion. } \\
\hline Water Depth ${ }^{\mathrm{d}}$ : & \multicolumn{3}{|l|}{$98.4 \mathrm{~m}(322.7 \mathrm{ft})$} \\
\hline DRILLING CONTRACTOR: & \multicolumn{3}{|l|}{ United Drilling, Inc. } \\
\hline GEOPHYSICAL LOGS BY: & \multicolumn{3}{|c|}{$\begin{array}{l}\text { Schlumberger Logging Services, Colog, Inc. Desert Research Institute, } \\
\text { Gyrodata }\end{array}$} \\
\hline SURVEYING CONTRACTOR: & \multicolumn{3}{|l|}{ Bechtel Nevada } \\
\hline
\end{tabular}

a Elevation of ground level at wellhead. 1929 National Geodetic Vertical Datum.

b Date completion string was cemented. Pump will be installed at a later date.

c Gravel adjacent to slotted intervals only. Additional gravel layers were used as stemming outside blank casing sections. See Table 7-1.

d Measured by IT on August 19, 1999, 24 days after stemming was complete (IT, 1999). 
about 30 minutes before tagging bottom again. No fill was found, and the drillers pulled the drill string out of the hole. Geophysical logging was not conducted prior to installation of casing.

A casing subcontractor ran and landed $13 \mathrm{~d}$-in. casing with a float collar installed between the first and second joints. Centralizers were installed at the middle and top of the first joint, and at the top

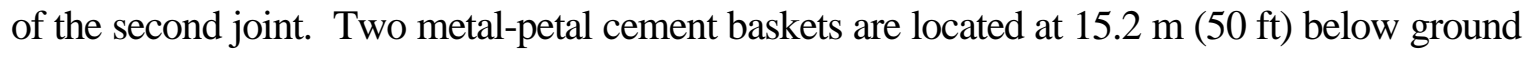
level. The casing was landed at a depth of $129.8 \mathrm{~m}$ (426 ft) on July 16, 1999, and after a stab-in sub was seated in the float collar, the seal was checked by pumping air down the drill pipe. Pre-flush clear water was pumped down the casing and the annulus prior to cementing. Neat type II cement was pumped inside the casing through the stab-in sub, followed by water to displace the cement into the annulus. The top of cement in the annulus was later determined by geophysical logs to be at the depth of approximately $73.2 \mathrm{~m}$ (240 ft). After the drill pipe was removed from the hole, cement was dropped on the cement baskets and allowed to harden before the remaining annular space was cemented to ground level. Cementing of the surface casing was completed on July 16, 1999. The top of cement inside the casing was tagged at $111.9 \mathrm{~m}$ (367 ft) when drilling resumed.

A bottom-hole assembly (BHA) made up with a 121/4-in. bit, and air-foam/polymer drilling fluid were used to drill the remainder of the hole. Cement was drilled from 111.9 to $130.5 \mathrm{~m}$ (367 to $428 \mathrm{ft}$ ), below which depth drilling continued into the formation. On July 18, 1999, at a depth of $325.5 \mathrm{~m}(1,068 \mathrm{ft})$, it was noted that the sumps were full, so drilling was stopped until the sump water could be analyzed for contaminants to determine whether it would be permissible to allow sump water to be discharged to the ground surface. During this 35 -hour drilling hiatus, the drillers pulled the BHA out of the hole to check it, and found that the bit and reamers were still in good condition; it was not necessary to replace the bit during the remaining drilling of Well ER-EC-8. Analyses of sump water for lead were found to be negative, so the overflow pipe from the unlined sump was opened. Drilling resumed on July 19, 1999, continuing uninterrupted to the planned TD of $609.6 \mathrm{~m}$ (2,000 ft), reached on July 21, 1999.

The amounts of polymer and foaming agent in the drilling fluid, and the fluid injection rate were adjusted as necessary during drilling to maintain superior circulation and penetration rate, and to minimize sloughing of material from the borehole wall. Fill encountered (due to sloughing) during drilling was minimal: fill was rarely encountered, though $0.6 \mathrm{~m}(2 \mathrm{ft})$ of fill was found on two connections, and $1.2 \mathrm{~m}$ (4 ft) of fill was tagged at the bottom of the hole prior to geophysical logging. 
Immediately after reaching TD, the drillers circulated fluid to condition the hole before geophysical logging of the borehole, which took place on July 22-23, 1999. Installation of the completion string began on July 24, 1999. Demobilization from the Well ER-EC-8 site began after gravel-packing and cementing were completed on July 26, 1999.

The directional survey run in the well on October 20,1999, indicates that at the lowest surveyed depth of $589.8 \mathrm{~m}(1,935 \mathrm{ft})$ the hole had drifted $1.6 \mathrm{~m}(5.1 \mathrm{ft})$ to the north of the collar location, and that the hole is relatively straight (no "dog legs").

A graphical depiction of drilling parameters including penetration rate, revolutions per minute, pump pressure, and weight on the bit is presented in Appendix A-1. See Appendix A-2 for a listing of casing materials. Drilling fluids and cements used in Well ER-EC-8 are listed in Appendix A-3.

\subsection{Drilling Problems}

No drilling problems were encountered at Well ER-EC-8, though minor borehole sloughing was noted. The only significant delays encountered were the result of fluid-management issues, discussed in paragraph 2.4.

\section{$2.4 \quad$ Fluid Management}

Drilling effluent was monitored according to the methods prescribed in the UGTA FMP (DOE, 1996a). The air-foam/polymer drill fluid was circulated down the inside of the drill string and back up the hole through the annulus ("conventional" or direct circulation) and then discharged into a sump. Water used to prepare drilling fluids came from the Coffer Dune Well, approximately $16.8 \mathrm{~km}(10.5 \mathrm{mi})$ north-northeast of Beatty, Nevada. Lithium bromide ( $\mathrm{LiBr}$ ) was added to the drill fluid as a tracer to provide a means of estimating groundwater production.

To manage the anticipated water production, two sumps were constructed prior to drilling (Figure 2-1). No contaminants were expected during drilling at this site, so neither sump was lined prior to drilling. Samples of drilling effluent were tested on-site hourly for the presence of tritium, and every eight hours for lead. The on-site monitoring results indicated that tritium remained at background levels, and lead levels were classed as "non-detectable" (less than 50 parts per billion) during the entire drilling operation (IT, 1999). Samples from the sumps were also analyzed by an off-site facility during and after drilling to verify on-site analyses and to demonstrate compliance with the FMP. 
On July 18, 1999, fluid discharge was diverted from sump 1 to sump 2 (before the fluid level in sump 1 reached the overflow pipe). Drilling was halted when both sumps were full, pending the results of analyses by an off-site laboratory of a fluid sample taken from the sump 1. The analysis showed values for analytes below the allowable FMP discharge levels, so the NNSA/NSO representative approved opening the overflow pipe on July 19, 1999. Water-quality data from the FMP samples are given in Appendix B.

The results of analyses of samples of drilling fluid collected at Well ER-EC-8 during drilling and after operations indicate that all fluid quality objectives were met, as shown on the fluid management reporting form dated September 14, 1999 (Appendix B). The form lists volumes of solids (drill cuttings) and fluids produced during well-construction operations, Stages I and II (i.e., vadose- and saturated-zone drilling; well development and aquifer testing will be conducted at a later date). The volume of solids produced was calculated using the diameter of the borehole (from caliper logs) and the depth drilled, and includes added volume attributed to a rock bulking factor. The volumes of fluids listed on the report are estimates of total fluid production, and do not account for any infiltration or evaporation of fluids from the sumps. 


\subsection{Geologic Data Collection}

This section describes the sources of geologic data obtained from Well ER-EC-8 and the methods of data collection. Improving the understanding of the subsurface structure, stratigraphy, and hydrogeology in the area southwest of Pahute Mesa was among the primary objectives of Well ER-EC-8, so the proper collection of geologic and hydrogeologic data from the well was considered fundamental to successful completion of the project.

Geologic data collected at Well ER-EC-8 consist of drill cuttings, sidewall core samples, and geophysical logs. Data collection, sampling, transfer, and documentation activities were performed according to applicable contractor procedures.

\subsection{Collection of Drill Cuttings}

Composite drill cuttings were collected from Well ER-EC-8 at 3.05-m (10-ft) intervals as drilling progressed from the depth of $36.6 \mathrm{~m}(120 \mathrm{ft})$ to the TD of the well at $609.6 \mathrm{~m}(2,000 \mathrm{ft})$. Triplicate samples were collected from 188 intervals, and in addition, the IT field representative collected two sets of reference samples from each of the cuttings intervals. One set was examined at the drill site for use in preparing field lithologic descriptions, and remains in the custody of IT (now StollerNavarro Joint Venture, IT's successor as NNSA/NSO's environmental contractor). The other set was sent to R. G. Warren at Los Alamos National Laboratory (LANL) where it remains. All other samples (i.e., three sets of 188 samples) are stored under secure, environmentally controlled conditions at the U.S. Geological Survey (USGS) Geologic Data Center and Core Library in Mercury, Nevada. One of these sample sets was sealed with custody tape at the rig site and remains sealed as an archive sample; one set was left unsealed in the original sample containers; and the third set was washed and stored according to standard USGS Core Library procedures.

\subsection{Sidewall Core Samples}

No sidewall sampling was attempted in the surface hole at Well ER-EC- 8 before installation of the 13d -in. surface casing. On July 23, 1999, after TD was reached and before the completion string was installed, Schlumberger collected sidewall samples between the depths of 157.9 and $594.4 \mathrm{~m}$ (518 and 1,950 ft) using a rotary sidewall coring tool. The sample locations were selected by the IT Field Representative on the basis of field lithologic logs (with consideration of borehole conditions determined from caliper $\operatorname{logs}$ ). Twenty samples were collected to help verify the stratigraphy and lithology of rocks in that portion of the borehole. A list of samples, including sample recovery and stratigraphic assignment for each sample, is given in Table 3-1. 
Table 3-1

Sidewall Core Samples from Well ER-EC-8

\begin{tabular}{|c|c|c|}
\hline $\begin{array}{l}\text { Core Depth } \\
\text { meters (feet) }\end{array}$ & $\begin{array}{c}\text { Length } \\
\text { Recovered }^{\text {a }} \\
\text { cm (in.) }\end{array}$ & $\begin{array}{c}\text { Stratigraphic } \\
\text { Unit }^{\mathrm{b}}\end{array}$ \\
\hline $157.9(518.0)$ & $5.08(2.0)$ & \multirow{9}{*}{ Tfb } \\
\hline $182.6(599.0)$ & $5.08(2.0)$ & \\
\hline $210.3(690.0)$ & $5.08(2.0)$ & \\
\hline $226.8(744.0)$ & $5.08(2.0)$ & \\
\hline $264.6(868.0)$ & $5.08(2.0)$ & \\
\hline $277.4(910.0)$ & $5.08(2.0)$ & \\
\hline $286.5(940.0)$ & $5.08(2.0)$ & \\
\hline $343.2(1,126.0)$ & $1.91(0.75)$ & \\
\hline $389.5(1,278.0)$ & $3.81(1.50)$ & \\
\hline $426.7(1,400.0)$ & $3.81(1.50)$ & \multirow{3}{*}{ Tmaw } \\
\hline $449.9(1,476.0)$ & $3.18(1.25)$ & \\
\hline $464.8(1,525.0)$ & $5.08(2.0)$ & \\
\hline $495.6(1,626.0)$ & $4.45(1.75)$ & \multirow{8}{*}{ Tmap } \\
\hline $516.0(1,693.0)$ & $2.54(1.0)$ & \\
\hline $542.5(1,780.0)$ & $3.81(1.50)$ & \\
\hline $554.7(1,820.0)$ & $5.08(2.0)$ & \\
\hline $570.0(1,870.0)$ & $2.54(1.0)$ & \\
\hline $584.0(1,916.0)$ & $4.45(1.75)$ & \\
\hline $594.1(1,949.0)$ & $4.45(1.75)$ & \\
\hline $594.4(1,950.0)$ & $3.18(1.25)$ & \\
\hline
\end{tabular}

a All samples collected by Schlumberger using a rotary mechanical sidewall coring tool.

b Stratigraphic assignments: Tfb $=$ Beatty Wash Formation ; Tmaw $=$ tuff of Buttonhook Wash; Tmap $=$ mafic-poor Ammonia Tanks Tuff. See Appendix $C$ for more information about the stratigraphy and lithology of Well ER-EC-8. 


\subsection{Sample Analysis}

Seventeen samples of drill cuttings from various depths in Well ER-EC-8 were submitted to the LANL Earth and Environmental Sciences Division - Geology and Geochemistry Laboratories for petrographic, mineralogic, and chemical analyses to aid in stratigraphic identification and for characterization of mineral alteration. All of the planned analyses have been completed, as listed in Table 3-2.

Table 3-2

\section{Rock Samples from Well ER-EC-8 Submitted for Analysis ${ }^{\text {a }}$}

\begin{tabular}{|c|c|}
\hline $\begin{array}{c}\text { Depth } \\
\text { meters (feet) }\end{array}$ & $\begin{array}{c}\text { Sample } \\
\text { Type }^{\text {c }}\end{array}$ \\
\hline $48.8(160)$ & DA \\
\hline $100.6(330)$ & DA \\
\hline $143.3(470)$ & DA \\
\hline $185.9(610)$ & DA \\
\hline $222.5(730)$ & DA \\
\hline $283.5(930)$ & DA \\
\hline $307.8(1,010)$ & DA \\
\hline $414.5(1,360)$ & DA \\
\hline $432.8(1,420)$ & DA \\
\hline $442.0(1,450)$ & DA \\
\hline $454.2(1,490)$ & DA \\
\hline $469.4(1,540)$ & DA \\
\hline $499.9(1,640)$ & DA \\
\hline $548.6(1,800)$ & DA \\
\hline $576.1(1,890)$ & DA \\
\hline $594.4(1,950)$ & DA \\
\hline $606.6(1,990)$ & DA \\
\hline \hline
\end{tabular}

a All planned analyses have been completed:

Petrographic: polished thin sections

Mineralogic: $x$-ray diffraction.

Chemical: $x$-ray fluorescence; wet chemical analysis for iron $\left(\mathrm{Fe}^{2+} / \mathrm{Fe}^{3+}\right)$.

b Depth represents base of 3.0-m (10-ft) sample interval.

c $\quad \mathbf{D A}=$ drill cuttings that represent lithologic character of interval. 


\subsection{Geophysical Data}

Geophysical logs were run to further characterize the lithology, structure, and water content of the rocks encountered. In addition, logs were run to evaluate borehole conditions, to determine the fluid levels during the course of drilling, and to monitor completion progress. Geophysical logging was conducted in two phases: prior to installing the completion well casing and during well installation (annulus investigation log). No logs were run in the unsaturated zone in the open borehole, however, gamma ray data were obtained through the casing in the upper part of the hole. A complete listing of the logs, dates run, depths, and service companies is provided in Table 3-3. The logs are available from BN in Mercury, Nevada, and copies are on file at the office of Stoller-Navarro Joint Venture in Las Vegas, Nevada.

The overall quality of the geophysical data collected was good. However, areas of extreme borehole wall rugosity or enlargement degraded data from logging tools that require close proximity to the borehole wall, such as density, neutron, borehole imager, and sonic travel time. Preliminary geophysical data from the logs are reproduced in Appendix D. 
Table 3-3

Well ER-EC-8 Geophysical Log Summary

\begin{tabular}{|c|c|c|c|c|c|c|}
\hline Geophysical Log Type a & Log Purpose & $\begin{array}{l}\text { Logging } \\
\text { Service }\end{array}$ & $\begin{array}{l}\text { Date } \\
\text { Logged }\end{array}$ & Run Number & $\begin{array}{l}\text { Bottom of Logged } \\
\text { Interval }{ }^{\mathbf{b}} \\
\text { meters (feet) }\end{array}$ & $\begin{array}{l}\text { Top of Logged } \\
\text { Interval }{ }^{\mathbf{b}} \\
\text { meters (feet) }\end{array}$ \\
\hline Temperature/Gamma Ray & $\begin{array}{l}\text { Saturated zone: groundwater } \\
\text { temperature/stratigraphic correlation }\end{array}$ & Schlumberger & 07/22/1999 & TL-1/GR-1 & $597.4(1,960)$ & 0 \\
\hline * Four Arm Caliper/Gamma Ray & $\begin{array}{l}\text { Borehole conditions, } \\
\text { cement volume calculation/ } \\
\text { stratigraphic correlation }\end{array}$ & Schlumberger & 07/22/1999 & CA4-1/GR-1 & $608.1(1,995)$ & $103.6(340)$ \\
\hline Ultrasonic Borehole Imager & $\begin{array}{l}\text { Saturated zone: lithologic } \\
\text { characterization, fracture and void } \\
\text { analysis. }\end{array}$ & Schlumberger & 07/22/1999 & BHTV-1 & $606.2(1,989)$ & $129.5(425)$ \\
\hline * Natural Gamma Ray Spectroscopy & $\begin{array}{l}\text { Stratigraphic correlation, mineralogy, } \\
\text { natural and man-made radiation }\end{array}$ & Schlumberger & 07/22/1999 & SGR-1 & $597.7(1,961)$ & 0 \\
\hline $\begin{array}{l}\text { *Epithermal Neutron/Density/ } \\
\text { Gamma Ray/ Caliper }\end{array}$ & $\begin{array}{l}\text { Total water content/lithologic } \\
\text { determination/stratigraphic } \\
\text { correlation/borehole conditions }\end{array}$ & Schlumberger & 07/22/1999 & $\begin{array}{l}\text { ENP-1/CDL-1/ } \\
\text { GR-2/CAL-1 }\end{array}$ & $606.6(1,990)$ & 0 \\
\hline $\begin{array}{l}\text { * Dual Laterolog/ *Spontaneous } \\
\text { Potential/Gamma Ray }\end{array}$ & $\begin{array}{l}\text { Saturated zone: water saturation/ } \\
\text { stratigraphic correlation }\end{array}$ & Schlumberger & 07/22/1999 & DLL- $1 /$ SP-1 ${ }^{c} /$ GR-3 & $605.6(1,987)$ & $129.5(425)$ \\
\hline $\begin{array}{l}\text { Gamma Ray/Digital Array Sonic } \\
\text { A. Wave-form and variable density } \\
\text { presentations } \\
\text { *B. Sonic porosity and travel time } \\
\text { (STC) computations }\end{array}$ & $\begin{array}{l}\text { Saturated zone: } \\
\text { A. Porosity, lithologic determination } \\
\text { B. Fracture identification }\end{array}$ & Schlumberger & 07/22/1999 & AC-1/GR-4 & $601.7(1,974)$ & $100.6(330)$ \\
\hline Mechanical Sidewall Coring Tool & Geologic Samples & Schlumberger & 07/23/1999 & MCT-1 & $594.1(1,949)$ & $157.9(518)$ \\
\hline * Chemistry/Temperature Log & $\begin{array}{l}\text { Groundwater chemistry and } \\
\text { temperature, formation } \\
\text { transmissivity }\end{array}$ & $\begin{array}{l}\text { Desert } \\
\text { Research } \\
\text { Institute }\end{array}$ & 07/23/1999 & 1 & $606.6(1,990)$ & $100.3(329)$ \\
\hline * Thermal Flow Log & $\begin{array}{l}\text { Rate and direction of groundwater } \\
\text { flow in borehole }\end{array}$ & $\begin{array}{l}\text { Desert } \\
\text { Research } \\
\text { Institute }\end{array}$ & 07/23/1999 & 1 & $512.1(1,680)$ & $176.8(580)$ \\
\hline Nuclear Annulus Investigation Log & Well construction monitoring & Colog & $\begin{array}{c}07 / 24- \\
26 / 1999\end{array}$ & AIN-1 & $593.8(1,948)$ & $2.4(8)$ \\
\hline Gyroscopic Directional Survey & Borehole deviation & Gyrodata & 10/20/1999 & 1 & $589.8(1,935)$ & 0 \\
\hline
\end{tabular}

a Logs presented in geophysical log summary, Appendix D, are indicated by *

b Depth below ground surface.

c Run number not recorded on header of printed log. 
This page intentionally left blank. 


\subsection{Geology and Hydrogeology}

This section describes the geology and hydrogeology of Well ER-EC-8. The basis for the discussions in Section 4.0 is the detailed lithologic log presented in Appendix C. The detailed lithologic log was developed using drill cuttings and sidewall core samples, geophysical logs, and drilling parameters. Results from petrographic, mineralogic, and chemical analyses provided by R. G. Warren of LANL (Warren, 2003; Warren et al., 2003) for select lithologic samples are incorporated into the lithologic $\log$ and used to confirm the general stratigraphic assignments determined mainly from microscopic examination of drill cuttings samples.

Interpretations of data from this well have been incorporated into the hydrostratigraphic model for the Pahute Mesa - Oasis Valley area (BN, 2002).

\subsection{Geology}

This section is subdivided into discussions of the stratigraphic section and structural features interpreted from Well ER-EC-8 data, followed by a discussion of alteration noted in samples from the well. Emphasis is placed on interpretation of the locations of caldera boundaries and related structures, as the distribution of aquifers in this area is believed to largely be controlled by caldera boundaries (Laczniak et al., 1996).

\subsubsection{Stratigraphy and Structure}

Well ER-EC-8 is located within Rocket Wash near its confluence with Thirsty Canyon Wash, approximately $6.4 \mathrm{~km}(4 \mathrm{mi})$ southeast of the summit of Thirsty Mountain (Figure 4-1). The well is also located just inside the western margin of the Rainier Mesa caldera, a caldera of the Timber Mountain caldera complex (TMCC). The TMCC is composed of at least two nested calderas, the Rainier Mesa caldera and the younger Ammonia Tanks caldera. The formation of these calderas is the result of the eruption of the Rainier Mesa Tuff (erupted 11.6 million years ago [Ma] [Sawyer et al., 1994]) and the Ammonia Tanks Tuff (erupted 11.45 Ma [Sawyer et al., 1994]); both tuffs are considered part of the Timber Mountain Group. Following the collapse of the Ammonia Tanks caldera, resurgence of a central dome created the present topographic expression of the TMCC, including Timber Mountain and the surrounding "moat" (Figure 4-1). Younger volcanic rocks partially filled the moat, burying most of the Timber Mountain Group rocks within the moat. Moat-filling units exposed at the surface near Well ER-EC-8 (Figure 4-2) consist mainly of tuff and rhyolite lava of the Volcanics of Fortymile 
This page intentionally left blank. 


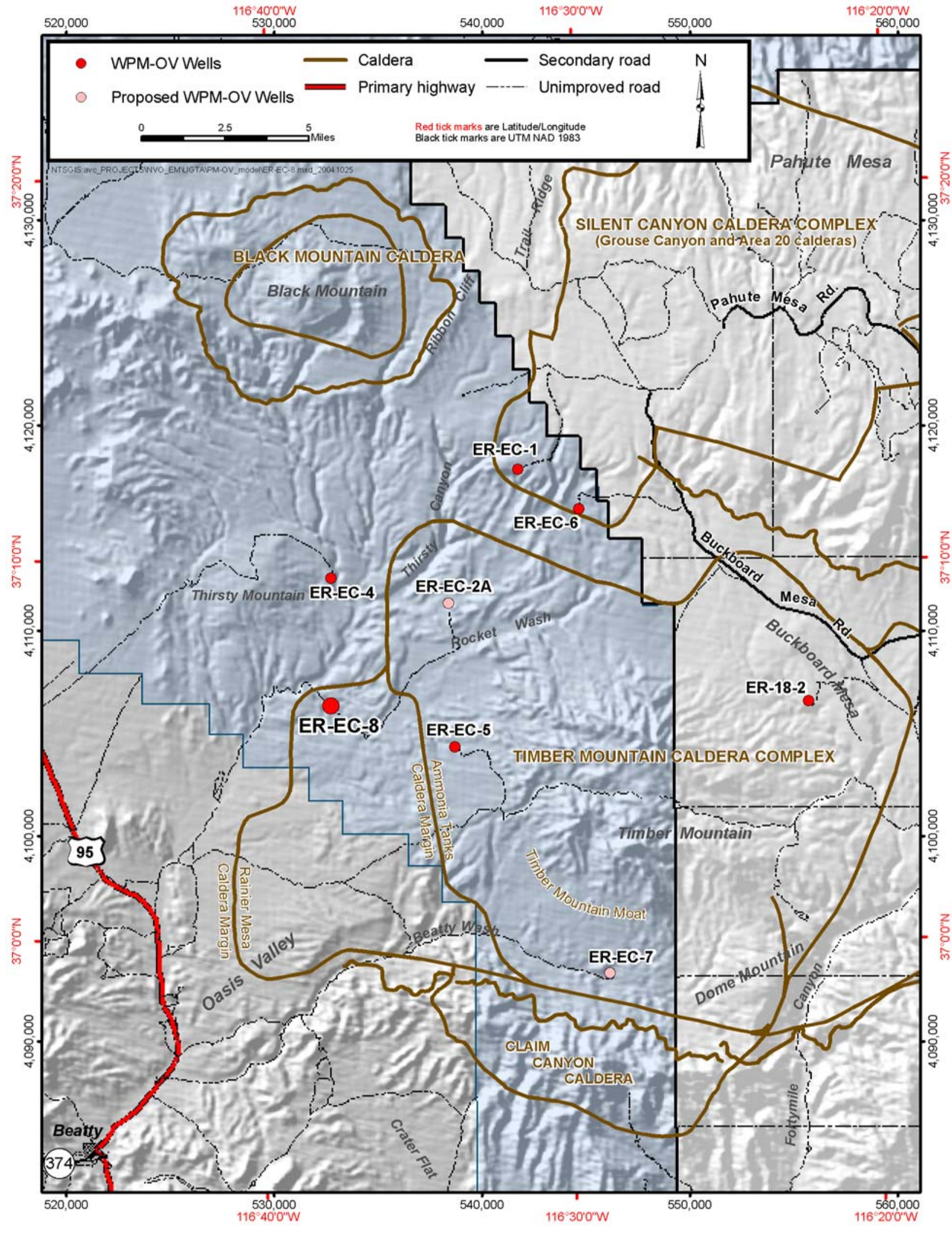

Figure 4-1

Map of Western Pahute Mesa - Oasis Valley Area Showing Theorized Locations of Caldera Boundaries (data from Wahl et al., 1997) 
This page intentionally left blank. 


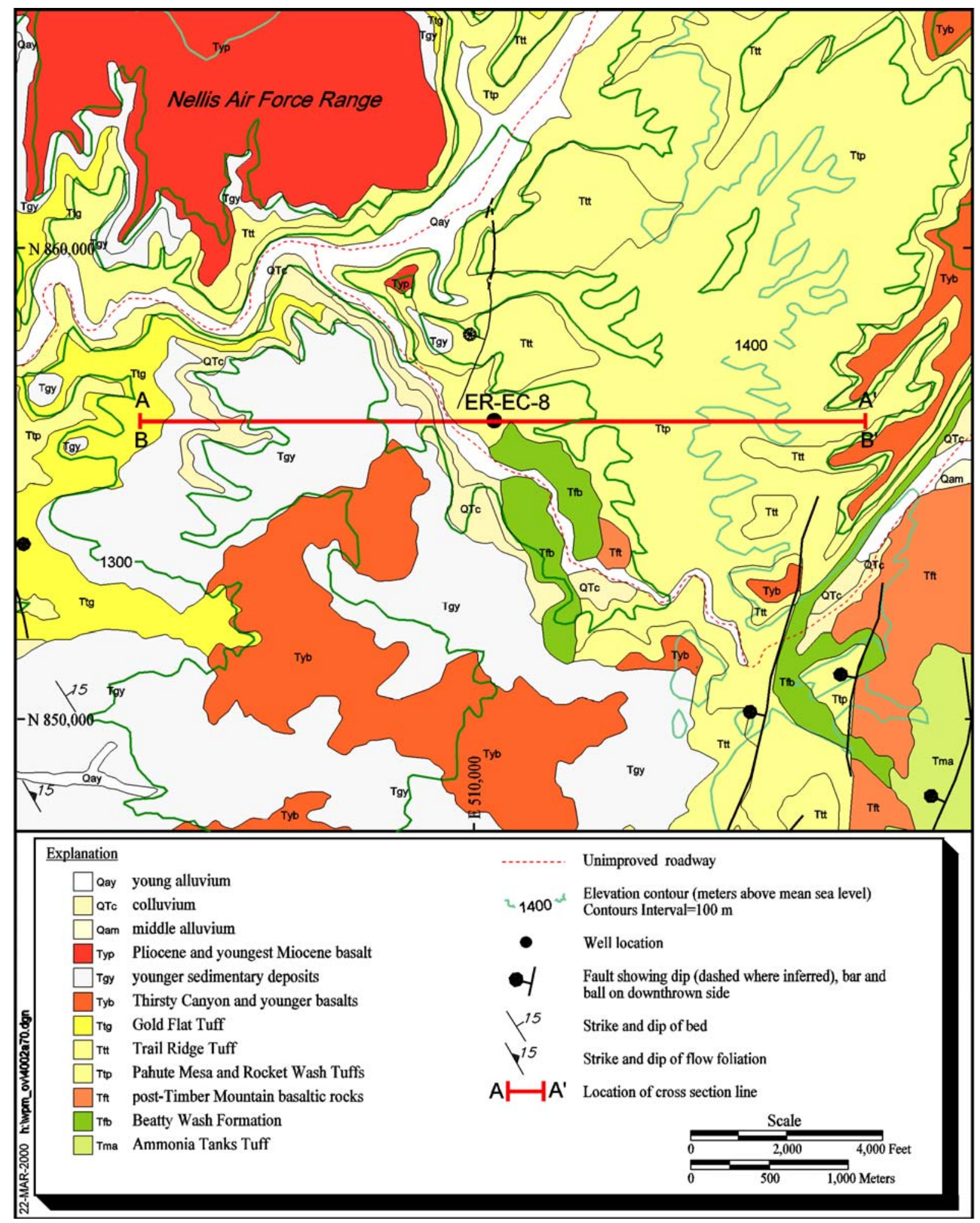

Figure 4-2

Surface Geologic Map of the Well ER-EC-8 Site

(Source: Wahl et al., 1997) 
This page intentionally left blank. 
Canyon, erupted from various vents near the TMCC shortly after collapse of the Ammonia Tanks caldera, and younger ash-flow tuff assigned to the Thirsty Canyon Group, erupted approximately 9.4 Ma (Sawyer et al., 1994) from the Black Mountain caldera located about $16.1 \mathrm{~km}$ (10 mi) north of the well (Figure 4-1). Mafic lavas that range in age from 4.63 to $11.4 \mathrm{Ma}$ are also present near the well (Fridrich et al., 1999b; Wahl et al., 1997; and Fleck et al., 1996). The well is located approximately $1.0 \mathrm{~km}(0.6 \mathrm{mi})$ southeast of the north-northeast trending, geophysically inferred Thirsty Canyon fault (Fridrich et al., 1999a). This fault zone has been interpreted to represent the western margin of the TMCC in the vicinity of Well ER-EC-8 (Grauch et al., 1997; Hildenbrand et al., 1999; Mankinen et al., 1999; and Fridrich et al., 1999a).

The mapped surface geology in the vicinity of Well ER-EC-8 indicates that drilling started in volcanic rocks of the Thirsty Canyon Group (Wahl et al., 1997 and Fridrich et al., 1999b). Rocks of the Thirsty Canyon Group are characterized by their general peralkaline mineralogy and lack of quartz phenocrysts (Wahl et al., 1997). After penetrating $42.4 \mathrm{~m}$ (139 ft) of nonwelded tuff assigned to the Thirsty Canyon Group, Well ER-EC-8 penetrated 378.9 m (1,243 ft) of nonwelded and bedded tuff assigned to the Beatty Wash Formation of the Volcanics of Fortymile Canyon. The assignment of this interval to the Beatty Wash Formation is based mainly on the presence of quartz, biotite, hornblende, and sphene. Results from laboratory analyses of drill cuttings samples from selected depths through this interval confirm the general assignment of these rocks to the Volcanics of Fortymile Canyon.

Below the Beatty Wash Formation the well penetrated a 68.3-m (224-ft) thick ash-flow tuff deposit assigned to the tuff of Buttonhook Wash, a unit closely related to the Ammonia Tanks Tuff of the Timber Mountain Group. This assignment is based on the ash-flow tuff lithology, and the presence of chatoyant sanidine, quartz, biotite, clinopyroxene, and sphene. The interval has a typical ash-flow tuff composition, with nonwelded to partially welded upper and lower portions and a more densely welded interior. Laboratory analyses confirm that most of the interval consists of units closely related to the Ammonia Tanks Tuff. However, the analyses suggest that the upper $18.3 \mathrm{~m}(60 \mathrm{ft})$ of the interval may consist of rocks related to the Volcanics of Fortymile Canyon.

Ash-flow tuff assigned to the mafic-poor Ammonia Tanks Tuff was encountered below the tuff of Buttonhook Wash. The assignment of mafic-poor Ammonia Tanks Tuff, also of the Timber Mountain Group, is mainly based on the ash-flow tuff lithology and presence of quartz, chatoyant sanidine, sphene, lithic fragments, and a minor amount of biotite. The well reached TD in the moderately welded, 
interior zone of the flow after penetrating the overlying nonwelded and partially welded zones, indicating that the well penetrated only the upper portion of the ash flow. Results from laboratory analyses indicate that the mineralogy of the rocks within this interval is consistent with that of the Ammonia Tanks Tuff. The stratigraphy and lithology of rocks in Well ER-EC-8 are illustrated in Figure 4-3.

The relative position, extent, and thickness of the stratigraphic units near Well ER-EC-8 are illustrated on the cross section in Figure 4-4. Although the total thickness of the Ammonia Tanks Tuff is unknown in this area, stratigraphic information suggests that the Ammonia Tanks Tuff at Well ER-EC-8 is an extra-caldera deposit, which would place the well outside the Ammonia Tanks caldera. Except where significant erosion has occurred (such as on Timber Mountain) intra-caldera Ammonia Tanks Tuff appears to be characterized by a thick (greater than $304.8 \mathrm{~m}$ [1,000 ft]) occurrence of the mafic-rich member of the Ammonia Tanks Tuff overlying thick mafic-poor Ammonia Tanks Tuff (DOE, 2003, 2004). The absence of mafic-rich Ammonia Tanks Tuff at Well ER-RC-8 is an indication that the well is located outside of the Ammonia Tanks caldera. Because of the petrographic similarity of tuff of Buttonhook Wash and the Ammonia Tanks Tuff, it is possible that the interval assigned to tuff of Buttonhook Wash is mafic-rich Ammonia Tanks Tuff. Even if this is the case, the unit is still too thin to represent an intracaldera occurrence. Well ER-EC-8 data, thus appear to corroborate earlier interpretations and recent drill hole data that place the western boundary of the Ammonia Tanks caldera approximately $4.3 \mathrm{~km}$ (2.7 mi) east of the well's location (Fridrich et al., 1999b; Wahl et al., 1997; Grauch et al., 1997; and Warren, 1994).

Because Well ER-EC-8 was not drilled deep enough to encounter Rainier Mesa Tuff (Figure 4-4), no direct stratigraphic evidence is available for determining the position of the well with respect to the Rainier Mesa caldera. However, the distribution of younger, moat-filling units, particularly the Beatty Wash Formation, provides useful information for determining the location of caldera boundaries. Based on surface exposures and drill hole data, the Beatty Wash Formation appears to be significantly thicker

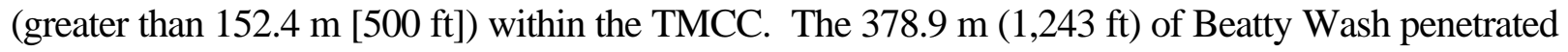
at Well ER-EC-8 suggests that the hole is within the Timber Mountain caldera. Because the hole is outside of the Ammonia Tanks caldera, but still within the TMCC, it is likely to be within the Rainier Mesa caldera. This interpretation is consistent with analyses of gravity and magnetic data in the region. These analyses indicate that Well ER-EC-8 is located on the down-thrown, southeast side of the northnortheast-trending, geophysically inferred Thirsty Canyon fault (Fridrich et al., 1999a). As mentioned 


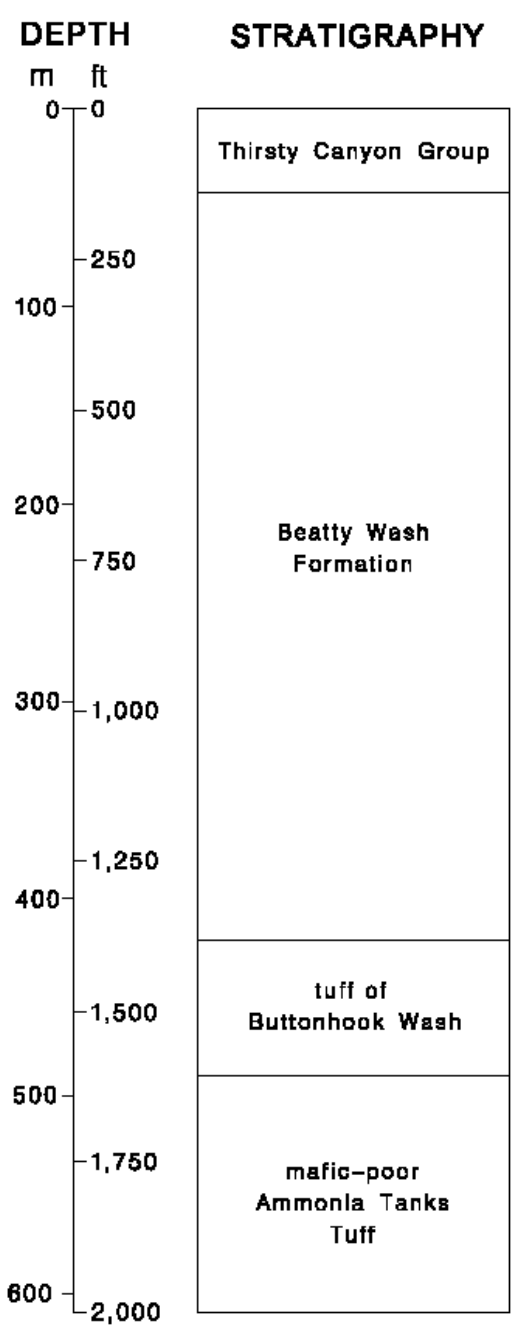

NOTE: See Appendlx $C$ for detalled llthologle descriptlans.

\section{LITHOLOGY}

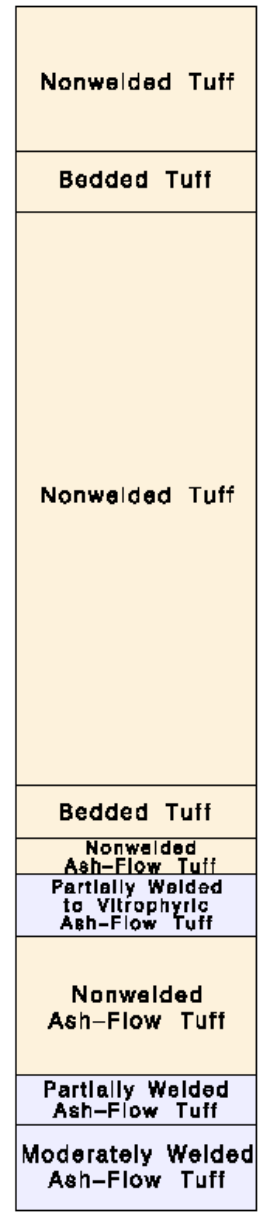

Welded AshFlow Tuff

Nonwelded end Bedded Tuff

\section{ALTERATION}

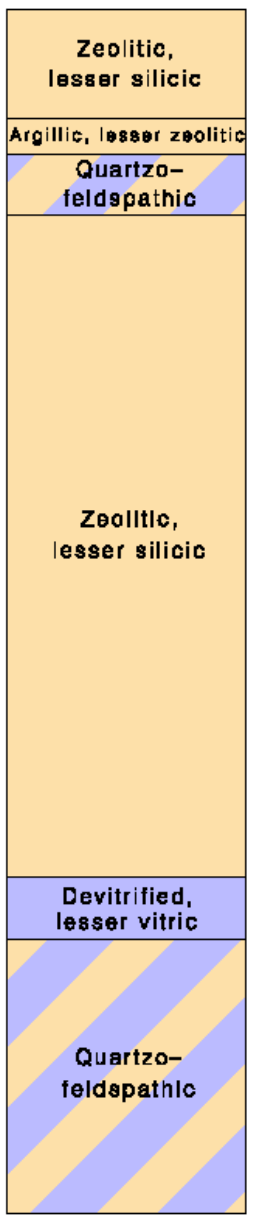

HYDROGEOLOGY

showing locatlons of

gravel-packed Intervalo

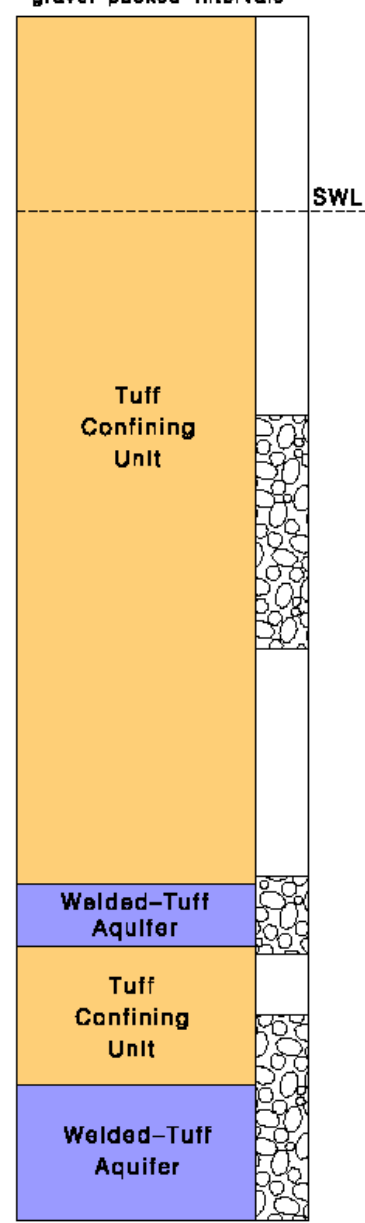

Unaltered

(devltrlfled or vitrlc) Aquifer

Zoolltle and/or Argillic

Confining unlt

Quartzofeldspathlc

Gravel-packed interva adjacent to slotted casing

SWL Preliminary composite statlo water level

Figure 4-3

Geology and Hydrogeology of Well ER-EC-8 
This page intentionally left blank. 


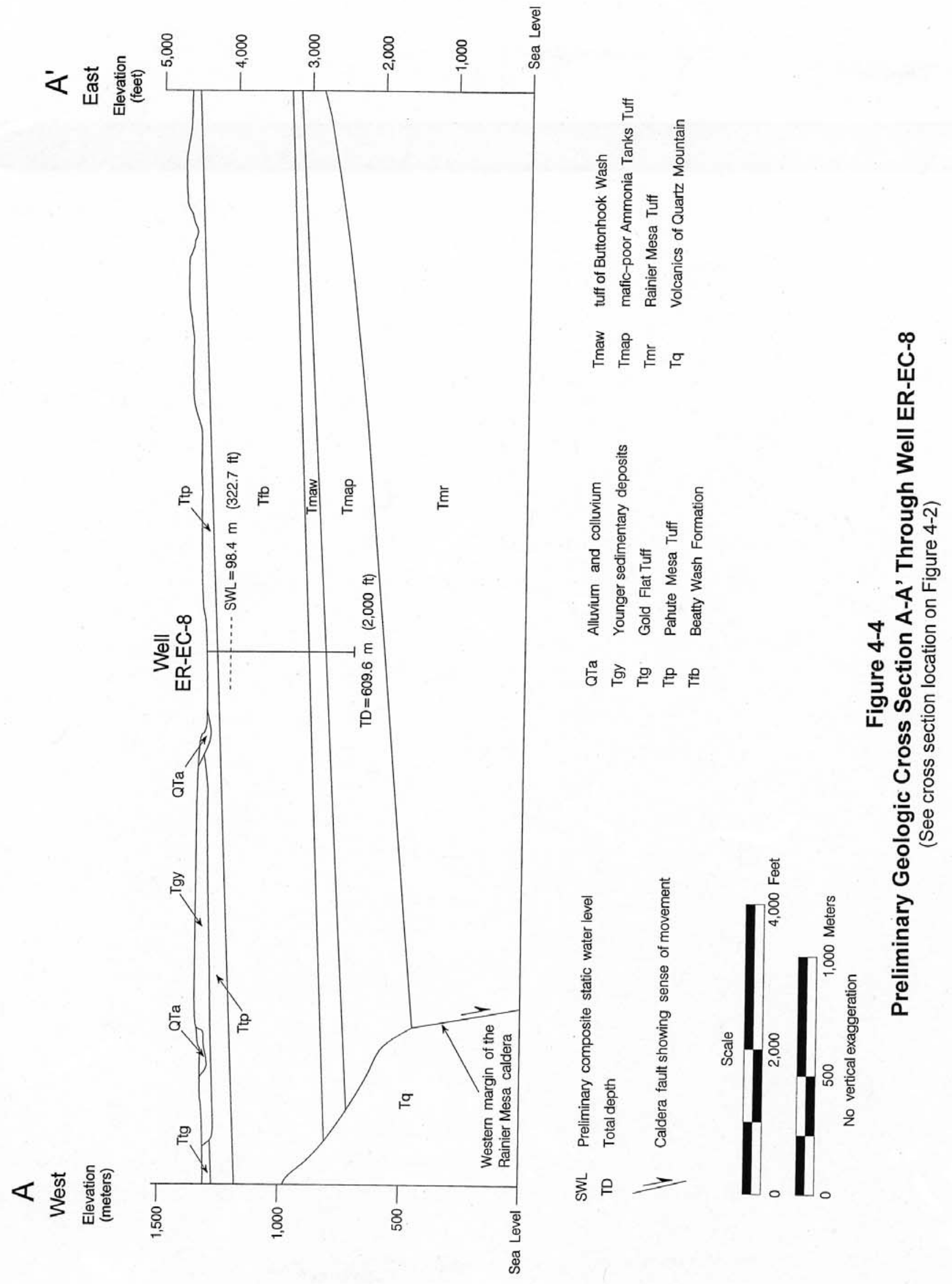


above, this fault zone is interpreted to coincide with the western margin of the TMCC (Grauch et al., 1997; Hildenbrand et al., 1999, Mankinen et al., 1999).

\subsubsection{Alteration}

Alteration has a significant effect on both the general hydraulic character of volcanic rocks and on how radionuclides migrate through these rocks. The predominant type of mineralogic alteration observed in each stratigraphic unit encountered in Well ER-EC-8 is illustrated on Figure 4-3. Above the depth of $439.5 \mathrm{~m}$ (1,442 ft), the nonwelded and bedded tuff of the Thirsty Canyon Group, Beatty Wash Formation, and upper portion of the tuff of Buttonhook Wash are mostly zeolitic, with lesser silicic and argillic alteration also present. The welded portions of the tuff of Buttonhook Wash in the interval 439.5 to $471.2 \mathrm{~m}(1,442$ to $1,546 \mathrm{ft})$ are mostly devitrified. From below the welded portions of the tuff of Buttonhook Wash, to the bottom of the hole, the rocks show higher temperature quartzofeldspathic alteration.

\subsection{Predicted Versus Actual Geology}

The predicted geology for Well ER-EC-8 (IT, 1998) was based on surface exposures (Wahl et al., 1997; Figure 4-2), the locations of caldera margins as interpreted by Warren (1994), and interpretations of geophysical data by Grauch et al. (1997). A comparison of the predicted and the actual stratigraphy is provided in Figure 4-5. The well is located within the Southern Thirsty Canyon structural block, a structural block characterized by structurally low, extracaldera Ammonia Tanks Tuff and thick intracaldera Rainier Mesa Tuff (Warren, 1994). Thus, the well was predicted to reach TD within the Ammonia Tanks Tuff after penetrating approximately $304.8 \mathrm{~m}(1,000 \mathrm{ft})$ of the unit. Although the well terminated in Ammonia Tanks Tuff as predicted, it penetrated only $120.1 \mathrm{~m}$ (394 ft) of Ammonia Tanks Tuff because the unit was found to be deeper than predicted. Conversely, the well penetrated a thicker interval than predicted of (overlying) post-Ammonia Tanks units such as the Beatty Wash Formation and tuff of Buttonhook Wash.

Because rhyolitic lava of the Beatty Wash Formation is mapped at the surface less than $152 \mathrm{~m}(500 \mathrm{ft})$ southeast of the Well ER-EC-8 (Figure 4-2), it was predicted that the well would penetrate a considerable thickness of Beatty Wash lava below the Thirsty Canyon Group rocks. However, only nonwelded and bedded tuff of the Beatty Wash Formation was encountered in the hole, indicating that the edge of the lava flow is generally coincident with the surface exposure, and does not extend northwestward beneath the Thirsty Canyon Group rocks to the Well ER-EC-8 location. 

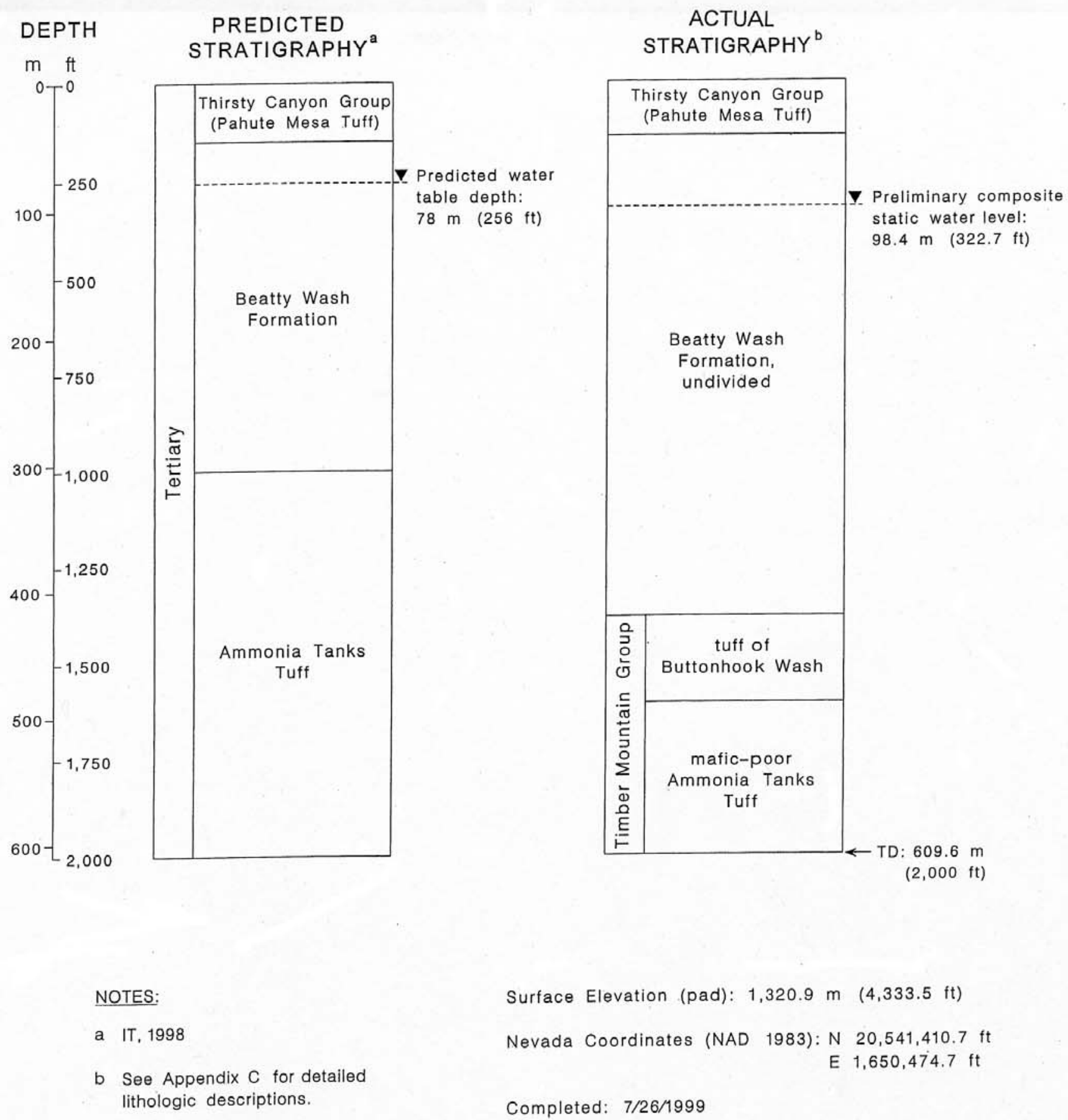

Figure 4-5

Predicted and Actual Stratigraphy at Well ER-EC-8 


\subsection{Hydrogeology}

The rocks of Well ER-EC-8 have been subdivided into hydrogeologic units, as illustrated in Figure 4-3. An interpretation of the distribution of these units is shown in cross section on Figure 4-6.

From the surface to the depth of $439.5 \mathrm{~m}(1,442 \mathrm{ft})$ the well penetrated mostly zeolitic nonwelded and bedded tuff of the Thirsty Canyon Group, Beatty Wash Formation, and the upper nonwelded portion of the tuff of Buttonhook Wash. Although zeolitized nonwelded and bedded tuffs typically behave as confining units, considerable water was produced in the lower portion of the interval below $198.1 \mathrm{~m}$ (650 ft). The presence of pervasive silicification through much of the interval (Figure 4-3) suggests that alteration process within these rocks may be more complex than typical zeolitic alteration, and thus result in a more complex distribution of hydraulic properties. A possible explanation for the production of water in what typically is considered a confining unit is that the alteration present, particularly the silicification, may make the rock more brittle, thus able to support the development of fractures. Observations in the borehole image log of fracturing below the depth of $198.1 \mathrm{~m}$ (650 ft) supports this explanation.

Surface exposures (Figure 4-2) of welded tuff at the top of the Thirsty Canyon Group and of lava within the Beatty Wash Formation mapped near the well also complicate predictions of the distribution of hydrogeologic units in this area. Aquifer-like rocks were not encountered in these units in the well and are not interpreted to occur along the line of the cross section.

Below the first thick interval of tuff confining unit, the well penetrated $31.7 \mathrm{~m}$ (104 ft) of welded-tuff aquifer formed of the welded portions of the tuff of Buttonhook Wash. Another interval of tuff confining unit was penetrated from the depth of 471.2 to $541.3 \mathrm{~m}$ (1,546 to 1,776 ft). This interval consists of the quartzo-feldspathic nonwelded portions of the lower portion of tuff of Buttonhook Wash and the upper portion of mafic-poor Ammonia Tanks Tuff. The hole reached TD in welded-tuff aquifer composed of moderately welded tuff of mafic-poor Ammonia Tanks Tuff. As Figures 4-4 and 4-6 show, the welded, mafic-poor Ammonia Tanks Tuff is interpreted to overlie thick intracaldera Rainier Mesa Tuff, resulting in a very thick interval of welded-tuff aquifer in the vicinity of the well. West of Well ER-EC-8, this interval was ponded against the caldera wall which is composed of volcanic rocks older than the Rainier Mesa Tuff. Surface geology exposed west of Well ER-EC-8 (Wahl et al., 1997) indicates these rocks are most likely Volcanics of Quartz Mountain which consist of welded and nonwelded tuffs and rhyolitic lava, thus forming an unknown distribution of lava-flow and welded-tuff aquifers and tuff confining units. 


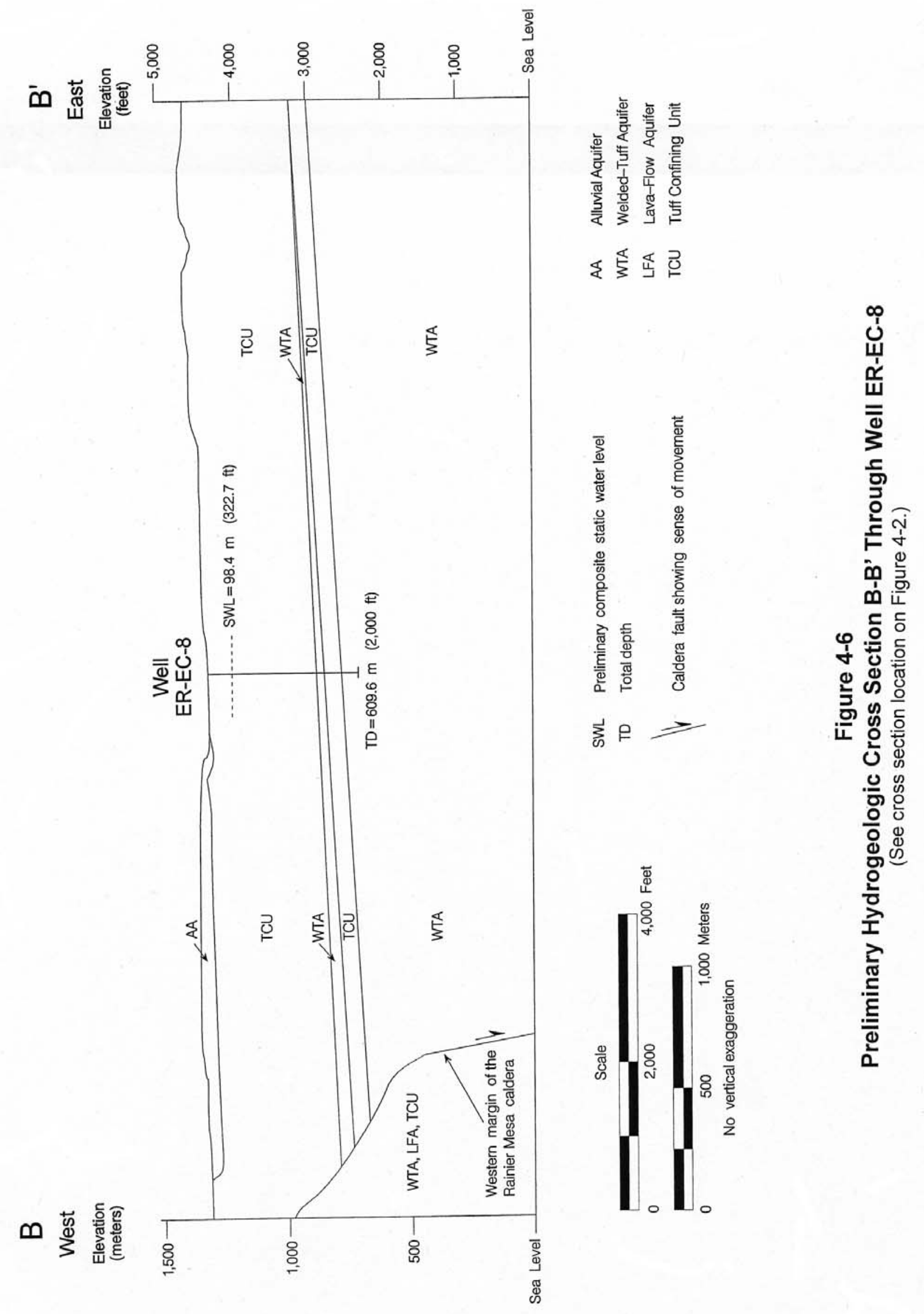


This page intentionally left blank. 


\subsection{Hydrology}

\subsection{Preliminary Water-Level Information}

The elevation of the water table at Well ER-EC-8 was projected to be approximately $1,257 \mathrm{~m}$ (4,124 ft), as derived from sparse hydrologic data for this region (IT, 1998). Based on the preconstruction estimate of surface elevation at the site, depth to water was expected at approximately $78 \mathrm{~m}$ (256 ft) (IT, 1998). Before installation of the surface casing, the fluid level was measured at a depth of approximately $98.1 \mathrm{~m}$ (322 ft), and depths to fluid between 98.1 and $98.8 \mathrm{~m}$ (322 and $324 \mathrm{ft}$ ) were obtained from various geophysical logs run on July 22, 1999 and July 23, 1999, before the completion string was installed. Twenty-four days after the completion string was stemmed, on August 19, 1999, IT obtained a fluid level depth in the well of $98.4 \mathrm{~m}$ (322.7 ft) (IT, 1999). Based on this composite fluid level depth and the as-built surface elevation of 1,320.9 $\mathrm{m}(4,333.5 \mathrm{ft})$, the fluid level elevation at Well ER-EC-8 is $1,222.5 \mathrm{~m}$ (4,010.8 ft). This is approximately $34.5 \mathrm{~m}(113 \mathrm{ft})$ below the predicted elevation of 1,257 $\mathrm{m}(4,124 \mathrm{ft})$. A transducer for monitoring of the water level was not installed as part of the completion activities.

\subsection{Water Production}

Water production was estimated on the basis of $\mathrm{LiBr}$ dilution data as measured by IT field personnel. The welded and vitrophyric ash-flow tuffs of Buttonhook Wash and the Ammonia Tanks Tuff were the primary water-producing units at this location, although significant water was also produced by nonwelded tuff of the Beatty Wash Formation. Measurable water production (approximately $22.0 \mathrm{lpm}$

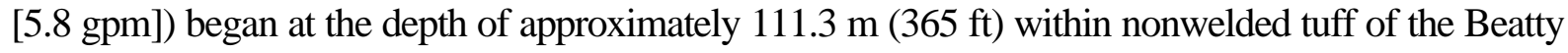
Wash Formation. The production rate remained relatively low (less than 757 lpm [200 gpm]) to the depth of about $198.1 \mathrm{~m}$ (650 ft) where it began to increase steadily within the nonwelded and bedded tuff of the Beatty Wash Formation and the tuff of Buttonhook Wash. At about $448.1 \mathrm{~m}(1,470 \mathrm{ft})$, near the contact with vitrophyric ash-flow tuff of Buttonhook Wash, water production increased from about 4,353 lpm (1,150 gpm) to about 5,299 lpm (1,400 gpm) and remained between 5,299 and 5,678 lpm $(1,400$ and 1,500 gpm) throughout most of the remainder of the drilling . Estimated water production rates are presented graphically in Appendix A-1.

\subsection{Preliminary Thermal Flow Meter Data}

Thermal flow meter (TFM) data, along with temperature, electrical conductivity (EC), and $\mathrm{pH}$ measurements can characterize borehole fluid variability, which may indicate inflow and outflow zones. 
The design of the completion string for Well ER-EC-8 was based in part on these data. Desert Research Institute (DRI) personnel made TFM measurements at five locations between the depths of 176.8 and $512.1 \mathrm{~m}$ (580 and 1,680 ft) in Well ER-EC-8 before the completion string was installed. In addition, DRI ran a chemistry log, including temperature, $\mathrm{EC}$, and $\mathrm{pH}$, from 100.3 to $606.6 \mathrm{~m}$ (329 to 1,990 ft).

The temperature of the borehole fluid varied only slightly from top to bottom, within a range of 0.58 degrees Celsius (C) (1.05 degrees Fahrenheit [F]). The minimum temperature of 38.24 degrees $\mathrm{C}$

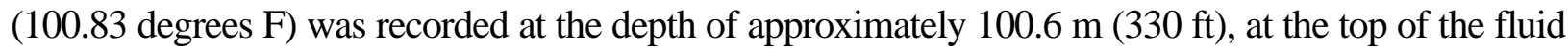
column. The maximum temperature of 38.82 degrees $\mathrm{C}$ (101.88 degrees $\mathrm{F}$ ) was recorded at the depth

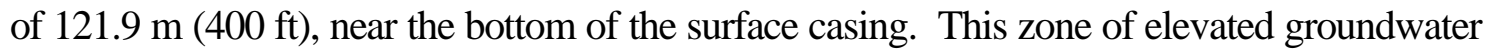
temperature is believed to reflect the high curing temperature of the cement used to seal the annulus at

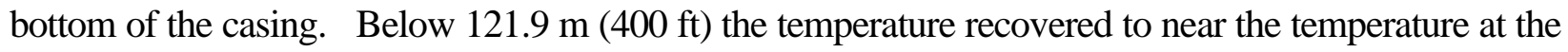
top of the fluid column, and then gradually increased to 38.65 degrees $\mathrm{C}$ (101.57 degrees F) at the bottom of the hole.

Preliminary analysis of a plot of the discrete TFM data points indicates a slight upward flow of water within the borehole at the uppermost and lowermost stations, with the remainder of the measurements showing downward flow between the depths of 205.7 and $449.6 \mathrm{~m}$ (675 and 1,475 ft). Plots of the TFM and chemistry log data are reproduced in Appendix D.

\subsection{Preliminary Groundwater Characterization Samples}

Following geophysical logging, DRI collected preliminary groundwater characterization samples within the open borehole. Two samples were collected at the depth of $278.4 \mathrm{~m}$ (800 ft). Analytical data from these initial samples, collected before formal well development, will provide a basis for comparison with future groundwater chemistry data. 


\subsection{Precompletion and Open-Hole Development}

The only precompletion development conducted in Well ER-EC-8 consisted of circulating fluid for

30 minutes to clean the borehole. This process was conducted immediately after TD was reached and prior to geophysical logging. 
This page intentionally left blank. 


\subsection{Well Completion}

\subsection{Introduction}

Well completion refers to the installation in a borehole of a string of pipe or casing that is slotted or screened at one or more locations along its length. The completion process also typically includes emplacement of backfill materials around the casing, with coarse fill such as gravel adjacent to the open intervals and impervious materials such as cement between the open intervals to isolate them. The casing serves as a conduit for insertion of a pump in the well, for inserting devices for measuring the fluid level, and for sampling, so that accurate potentiometric and water chemistry data can be obtained from a known portion of the borehole.

Completion activities at Well ER-EC-8 took place on July 24 to 26, 1999, with the exception of the submersible pump which will be installed at a later date. Figure 7-1 is a schematic of the final wellcompletion design for Well ER-EC-8; Figure 7-2 shows a plan view and profile of the wellhead surface completion; and Table 7-1 is a construction summary for the well. Data for this section were obtained from daily operations and activity reports, casing records, and cementing records provided by the BN Drilling Department. Information from the preliminary IT data report (IT, 1999) was also consulted for preparation of this section.

\subsection{Well Completion Design}

The final completion design differs slightly from the proposed design, as described in the following paragraphs.

\subsubsection{Proposed Completion Design}

The original completion design (IT, 1998) was based on the assumption that Well ER-EC-8 would penetrate and reach TD in the thick welded-tuff aquifer of the Ammonia Tanks Tuff. The nominal well design called for a single completion string consisting of 51/2-in. stainless steel casing, with every other joint slotted, suspended on carbon-steel $7 \mathrm{e}$-in. casing. The slotted portion of the well completion string was to extend through the welded-tuff aquifer of the Ammonia Tanks Tuff. The proposed completion design also called for the isolation (using blank [non-slotted] casing) of low transmissivity zones within the completion interval, if such zones could be identified. 


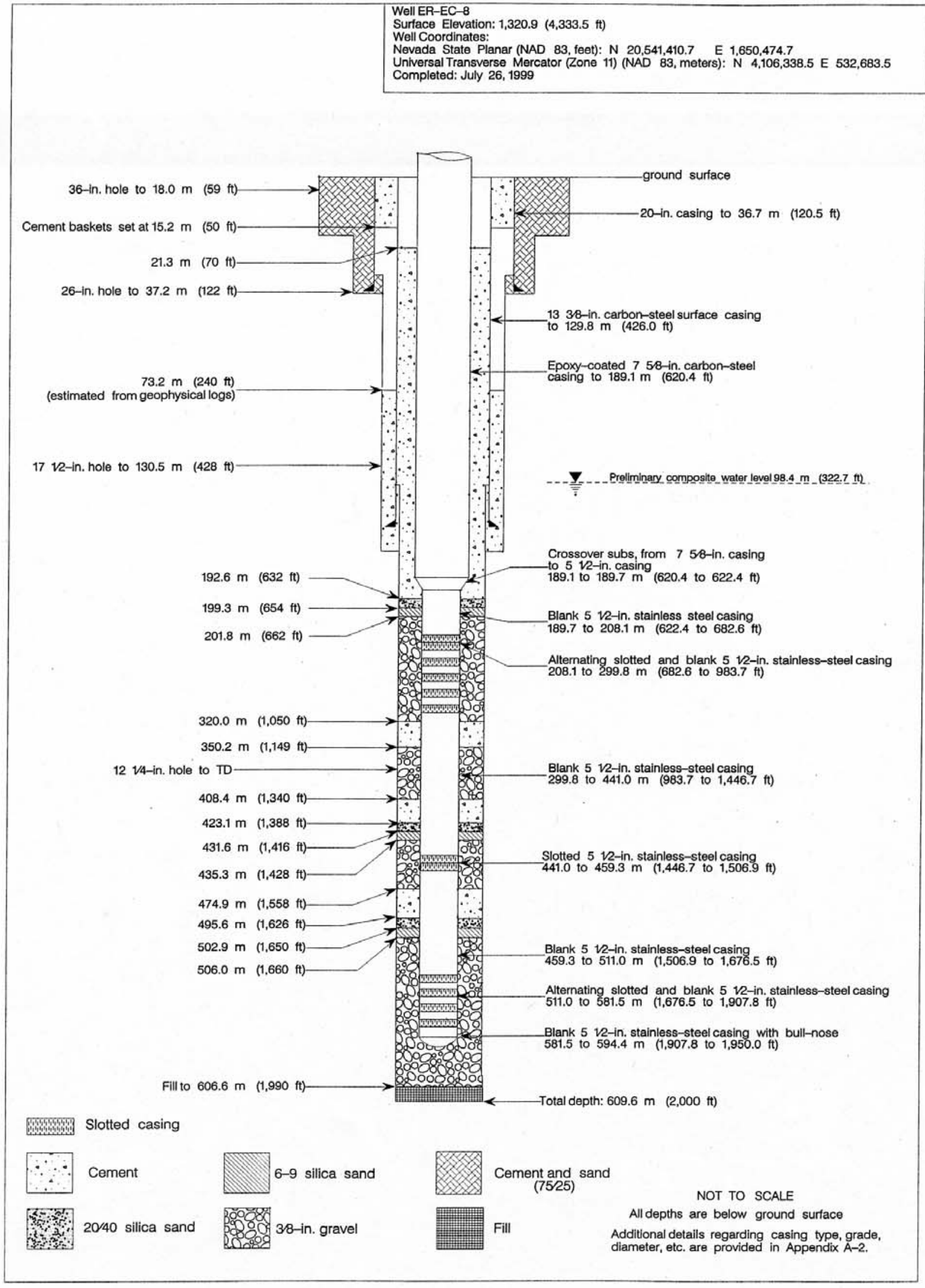

Figure 7-1

As-Built Completion Schematic for Well ER-EC-8 


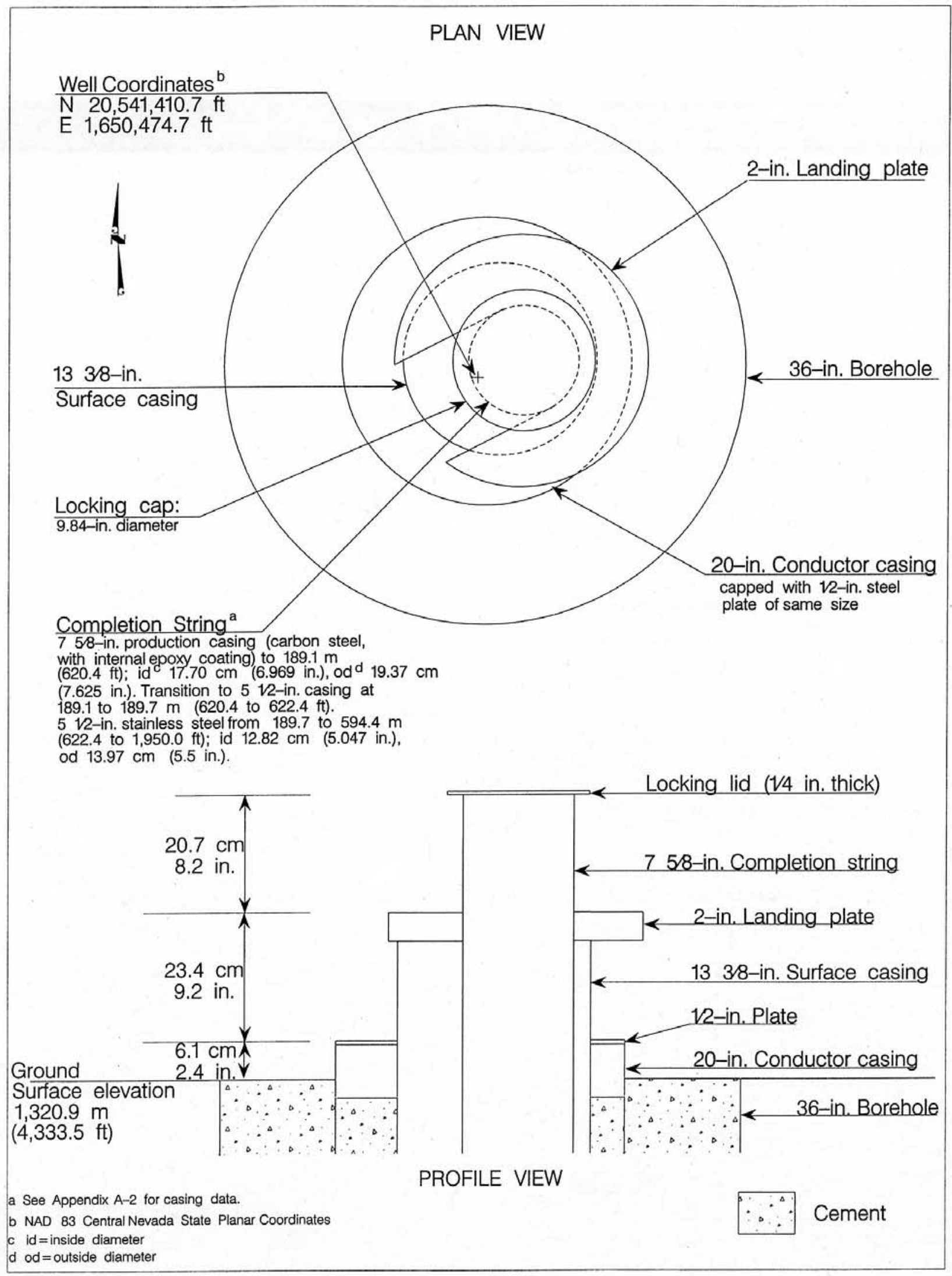

Figure 7-2

Wellhead Diagram for Well ER-EC-8 
Table 7-1

Well ER-EC-8 Completion String Construction Summary

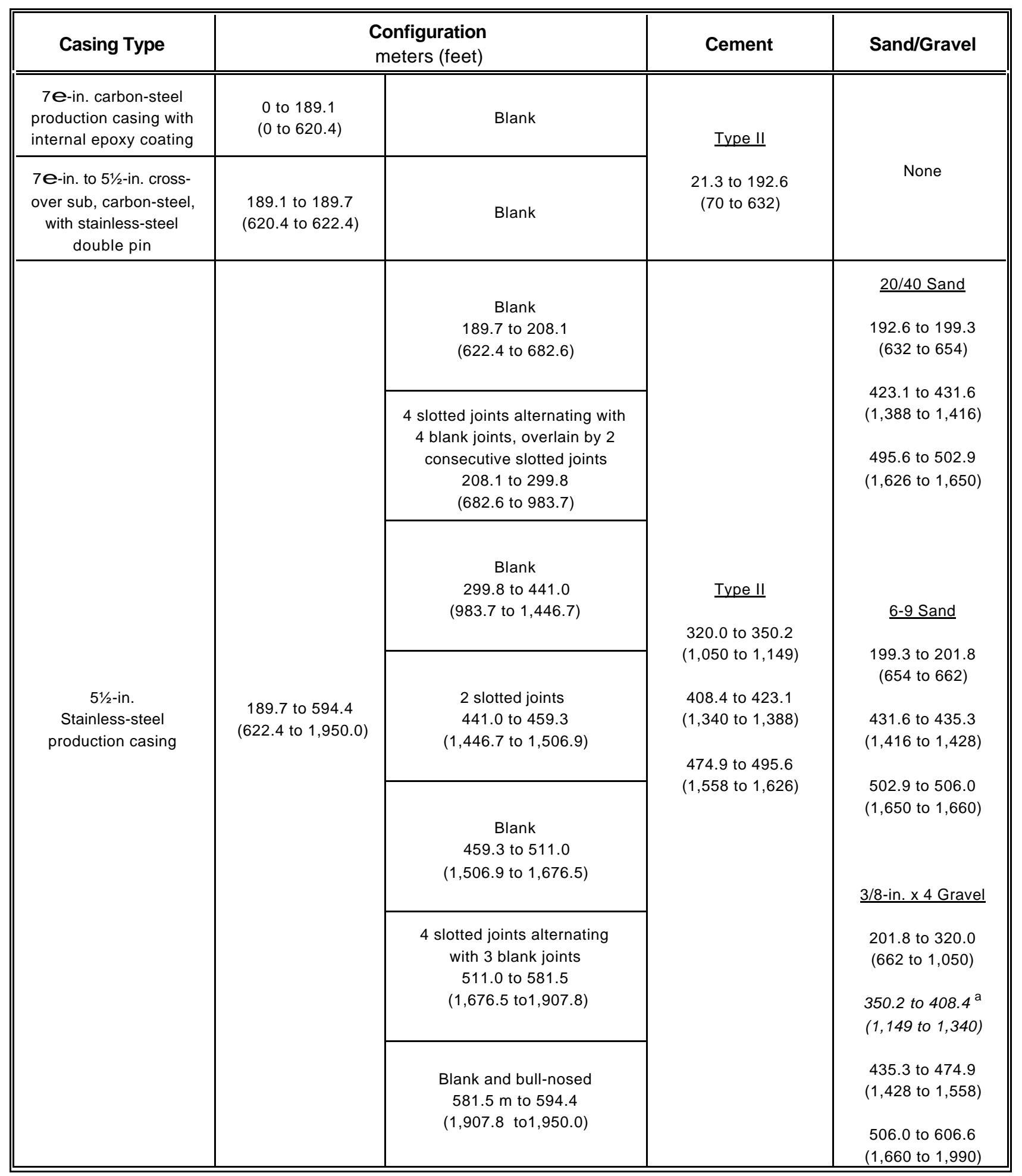

a Gravel section not adjacent to slotted intervals. 


\subsubsection{As-Built Completion Design}

The design of the Well ER-EC-8 completion was determined through consultation with members of the UGTA Technical Working Group, on the basis of on-site evaluation of data such as lithology and water production, drilling data (lost circulation, etc.), data from various geophysical logs, and from thermalflow and water chemistry logs.

The as-built completion design for Well ER-EC-8 provides access to two welded-tuff aquifers within the Ammonia Tanks Tuff and the tuff of Buttonhook Wash, and a portion of the Beatty Wash Formation (Figure 7-1). The composition of the string summarized here is detailed on Table 7-1, and the casing materials are listed in Appendix A-2. The lower section of the completion string, from 189.7 to $594.4 \mathrm{~m}$ (622.4 to 1,907.8 ft), is type T304L stainless-steel casing with an outside diameter of $13.97 \mathrm{~cm}$ (5.5 in.) and an inside diameter of $12.82 \mathrm{~cm}$ (5.047 in.). The top of the 51/2-in. casing is

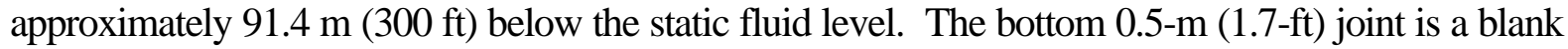
with a bull-nose sub which served as a guide shoe so that the string did not catch on ledges, etc., as it was inserted in the open hole. Above the 51/2-in. casing, a 0.6-m (1.9-ft) long crossover sub serves as the transition to the upper part of the string, which is $7 e$-in. carbon-steel production casing with an internal epoxy coating.

The lowest slotted interval, 511.0 to $581.5 \mathrm{~m}(1,676.5$ to $1,907.8 \mathrm{ft})$, is open to a welded-tuff aquifer of the Ammonia Tanks Tuff. (See Figure 4-3 for an illustration of gravel-pack locations relative to hydrogeologic units.) This casing interval consists of two slotted joints alternating with two blank joints. The second slotted interval, 441.0 to $459.3 \mathrm{~m}$ (1,446.7 to $1,506.9 \mathrm{ft})$, is open to a vitrophyric weldedtuff aquifer of the tuff of Buttonhook Wash, and consists of two consecutive slotted joints. The uppermost slotted interval, 208.1 to $299.8 \mathrm{~m}$ (682.6 to $983.7 \mathrm{ft}$ ), consists of four slotted joints alternating with four blank joints, overlain by two consecutive slotted joints, and is open to nonwelded tuff of the Beatty Wash Formation. This interval is classified as a tuff confining unit, but was selected as a completion zone on the basis of flow-log data.

The openings in each slotted casing joint are $0.198 \mathrm{~cm}(0.078 \mathrm{in}$.$) wide and 5.1 \mathrm{~cm}(2 \mathrm{in}$.$) long, cut in$ rings of 18 slots (spaced 20 degrees apart around the joint). The rings are spaced $15.2 \mathrm{~cm}(6 \mathrm{in}$.) apart, and the longitudinal centers of the slots in each ring are staggered 10 degrees from the slot centers in the next ring. No slots are cut within $0.6 \mathrm{~m}(2 \mathrm{ft})$ of the ends of the slotted joints to assure that the strength of the connections is not degraded. 


\subsubsection{Rationale for Differences between Actual and Proposed Well Design}

In addition to the expected welded-tuff aquifer of the Ammonia Tanks, a vitrophyric welded-tuff aquifer assigned to the tuff of Buttonhook Wash was encountered. The completion design was modified to include a completion zone in this aquifer. Another completion zone was also constructed near the top of the saturated section. This zone was selected on the basis of preliminary water production data and flow-log data that indicated that this section of nonwelded tuff of the Beatty Wash Formation was a better water producer than expected. However, the basic plan of installing a single string consisting of larger diameter carbon-steel casing above the water table and smaller diameter stainless-steel casing in the saturated zone was accomplished.

\subsection{Well Completion Method}

A "tremie" line and the completion string were landed after a brief period of circulation and conditioning of the hole. The three completion zones were gravel-packed and isolated from each other with sand and cement barriers. One additional gravel layer (instead of cement) was placed adjacent to a blank interval (Figure 7-1; Table 7-1) to save time waiting for cement deliveries. Caliper logs were used to calculate the volumes of stemming materials needed during well completion. Well-construction materials were inspected according to relevant procedures; standard decontamination procedures were employed to prevent the introduction of contaminants into the well.

The filter pack around each open interval consists of $0.95-\mathrm{cm}(\mathrm{d}$-in.) by 4-mesh washed gravel, with 6-9 Colorado silica sand directly above the gravel, and 20/40 silica sand on top of the 6-9 sand. In this stemming design, developed by the UGTA program at the NTS, the layer of 20/40 sand serves as a barrier to any fluids that might seep from the cement above, preventing cement fluids from contaminating the groundwater (fluids from the cement would have the effect of drastically raising the $\mathrm{pH}$ of the groundwater). The underlying layer of 6-9 sand prevents the 20/40 sand from infiltrating the gravel-packed interval. All cement used in stemming the completion string was Type II Portland cement with no additives. A clear-water pre-flush and back-flush were made at each stage of cement emplacement. Gravel, sand, and cement were emplaced through a $2 f$-in. Hydril ${ }^{\circledR}$ tremie line that was withdrawn as the completion process progressed. A nuclear annulus investigation log was used to monitor the emplacement of stemming materials. As-built positions of the well materials are shown on Figure 7-1 and listed in Table 7-1.

Stemming of the hole began with the first gravel pack emplaced from 606.6 to $506.0 \mathrm{~m}$ (1,990 to $1,660 \mathrm{ft}$ ), outside the lowest interval of slotted casing, on top of $1.2 \mathrm{~m}(4 \mathrm{ft})$ of fill at the bottom of the 
hole. This gravel pack is topped by a sand barrier to the depth of $495.6 \mathrm{~m}(1,626 \mathrm{ft})$, followed by cement, poured in three stages up to $474.9 \mathrm{~m}(1,558 \mathrm{ft})$. The second gravel pack was placed between the depths of 474.9 and $435.3 \mathrm{~m}$ (1,558 and 1,428 ft), adjacent to the middle slotted interval; this gravel was topped with sand to the depth of $423.1 \mathrm{~m}$ (1,388 ft), and cement to the depth of $408.4 \mathrm{~m}$ $(1,340 \mathrm{ft})$. A layer of gravel was placed between 408.4 and $350.2 \mathrm{~m}(1,340$ and 1,149 ft), adjacent to a blank casing interval, and is capped with cement to the depth of $320.0 \mathrm{~m}$ (1,050 ft). Another gravel layer was placed around the uppermost slotted casing interval between the depths of 320.0 and $201.8 \mathrm{~m}$ (1,050 and $662 \mathrm{ft})$. This gravel layer was capped with sand to the depth of $192.6 \mathrm{~m}$ (632 ft). The final cemented section extends to the depth of $21.3 \mathrm{~m}$ (70 ft).

The drill rig was released after cementing was completed. Hydrologic testing was planned as a separate effort, so a pump was not installed in the well, and no well-development or pumping tests were conducted immediately after completion. 
This page intentionally left blank. 


\subsection{Actual versus Planned Costs and Scheduling}

The BN cost model developed for Well ER-EC-8 was based on drilling to the planned TD of $609.6 \mathrm{~m}$ $(2,000 \mathrm{ft})$. The drilling program baseline projected that it would require 21 days to accomplish drilling of the surface and main holes, logging, and completion for the well, assuming the conductor hole would already have been constructed by BN. The actual time spent to drill the main and surface holes, and install the completion string in Well ER-EC-8 was 13 days. A graphical comparison, by day, of planned and actual well-construction activities is presented in Figure 8-1.

The cost analysis for Well ER-EC-8 begins with drilling of the surface hole, after construction of the conductor hole. The construction cost for Well ER-EC-8 includes all drilling costs: charges by the drilling subcontractor; charges by other support subcontractors (including compressor services, drilling fluids, bits, casing services, down-hole tools and, and geophysical logging); and charges by BN for mobilization and demobilization of equipment, cementing services, completion materials, radiation technicians, inspection services, and geotechnical consultation. The cost of building roads, the drill pad, and sumps is not included, and the cost of well-site support by IT is not included.

The total planned cost for constructing Well ER-EC-8 was $\$ 1,060,066$. The actual cost was $\$ 872,029$, or 17.7 percent less than the planned cost, which reflects the shorter time necessary to construct the well than expected. Figure 8-2 presents a comparison of the planned (baseline task plan) and actual cost, by day, for drilling and completing Well ER-EC-8. 


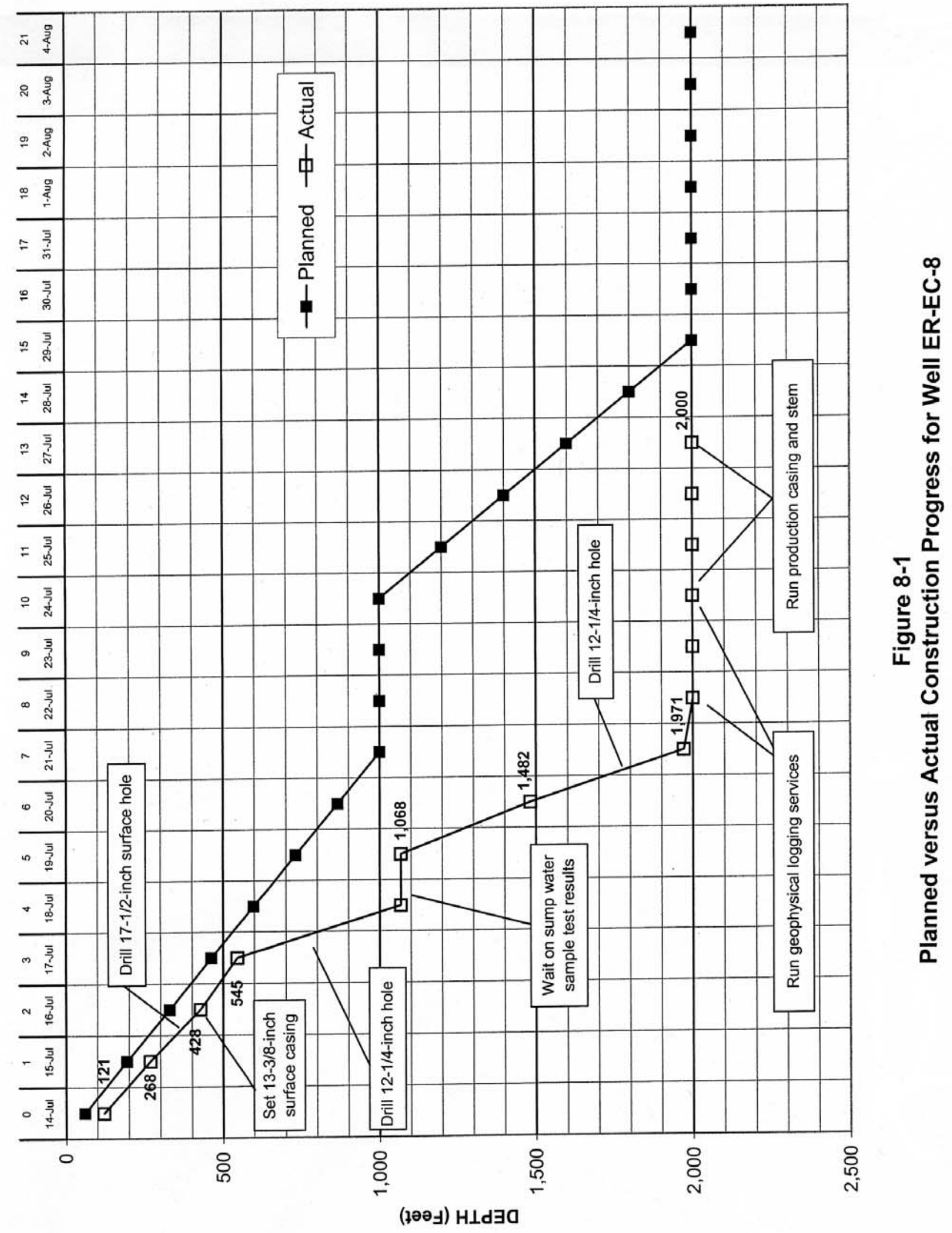




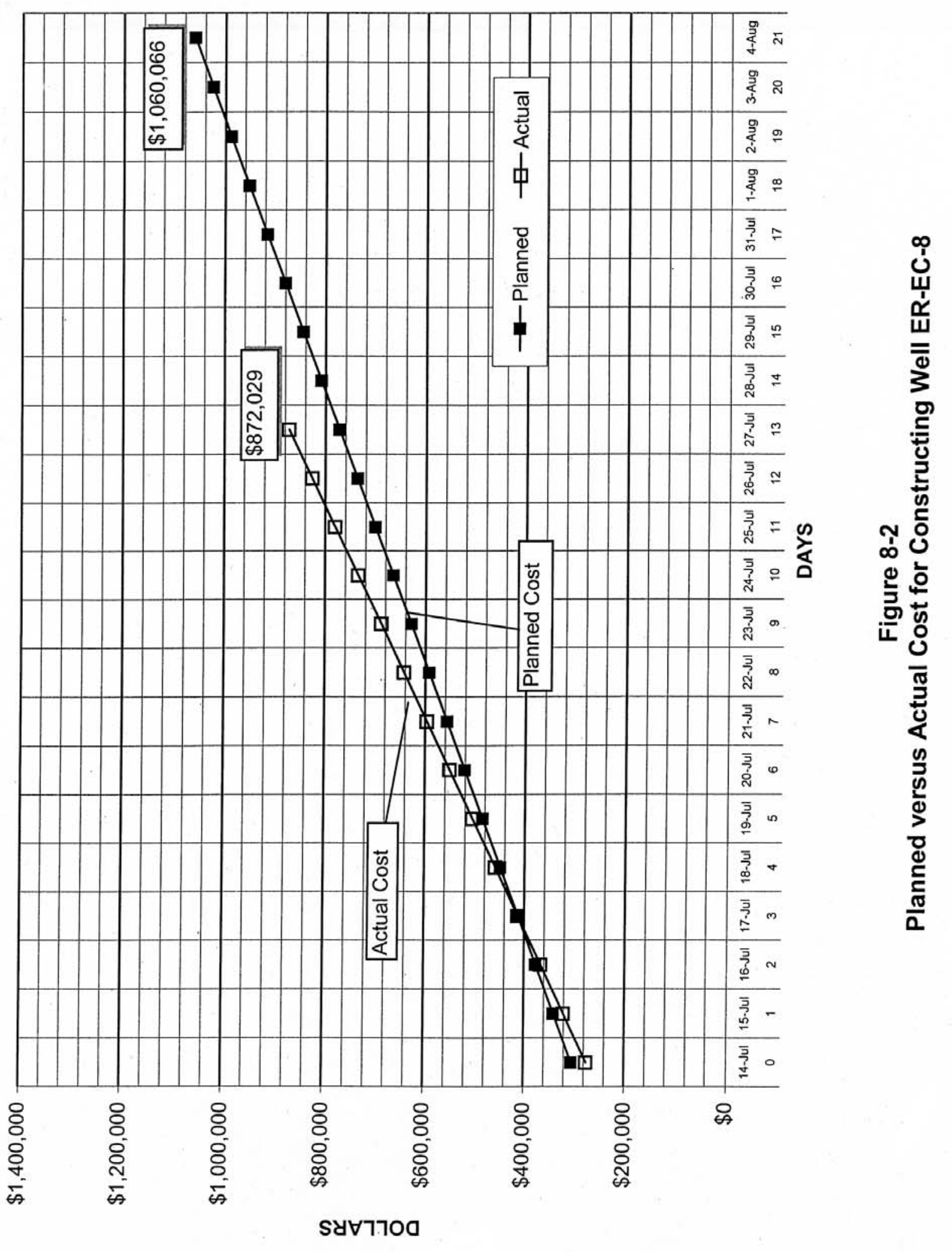


This page intentionally left blank. 


\subsection{Summary, Recommendations, and Lessons Learned}

\subsection{Summary}

Subcontractor drilling at Well ER-EC-8 commenced on July 14, 1999, and concluded on July 21, 1999, when the planned TD of $609.6 \mathrm{~m}$ (2,000 ft) was reached. After geophysical logging was conducted, the completion string was installed and gravel-packed, and the hole was stemmed to the depth of $21.3 \mathrm{~m}$ (70 ft) on July 24 to 26, 1999. Crews worked on a 7-days-per-week, 24-hoursper-day schedule for most of the operation. Thirteen working days were expended to drill the surface and main holes, conduct geophysical logging, and install the completion string. No significant problems were encountered during construction of Well ER-EC-8.

No radionuclides above background were encountered in the groundwater produced from Well ER-EC-8. The static fluid level consistently stabilized at the depth of approximately $98.5 \mathrm{~m}$ (323 ft) during drilling. IT personnel obtained a fluid level of 98.4 m (322.7 ft) on August 19, 1999, 24 days after the completion string was stemmed.

Composite drill cuttings were collected every $3 \mathrm{~m}$ (10 ft) from $36.6 \mathrm{~m}$ (120 ft) to TD. Twenty sidewall core samples were collected in the interval 157.9 to $594.4 \mathrm{~m}$ (518 to 1,950 ft). Geophysical logging was not conducted in the upper part of the hole before installation of the surface casing, but was conducted in the lower part of the hole before installation of the completion string. Some geophysical data however, were obtained for rocks behind the casing. Some of these logs were used to aid in construction of the well, while others help to verify the geology and determine the hydrologic characteristics of the rocks.

A single completion string with three gravel-packed, slotted intervals, was installed in Well ER-EC-8. A string of 51/2-in. stainless-steel casing installed below the water table is suspended from $7 e$-in. carbon-steel casing (with an internal epoxy coating) which extends to the surface. The open intervals in the 51/2-in. casing are centered within the gravel-pack intervals that are located at 201.8 to $320.0 \mathrm{~m}$ (662 to $1,050 \mathrm{ft}$ ); 435.3 to $474.9 \mathrm{~m}$ (1,428 to $1,558 \mathrm{ft}$ ); and 506.0 to $606.6 \mathrm{~m}$ (1,660 to 1,990 ft). These intervals are open to nonwelded tuff of the Beatty Wash Formation, and welded-tuff aquifers of the tuff of Buttonhook Wash and the Ammonia Tanks Tuff. 


\subsection{Recommendations}

The planned pump installation, well development, groundwater sampling, and hydrologic testing must be conducted at Well ER-EC-8 to accomplish the remaining objectives for this well-construction effort.

\subsection{Lessons Learned}

The efficiency of drilling and constructing wells to obtain hydrogeologic data in support of the UGTA project continues to improve as experience is gained with each new well. Yet each new well produces some "lessons learned" that can be applied to improve future well-construction projects. Very few problems were encountered during construction of Well ER-EC-8, however, the following items were noted:

- High water production during drilling of the lower portion of the borehole caused excessive dilution of the $\mathrm{LiBr}$ groundwater tracer solution. Thus, higher concentrations of the tracer were added to compensate for the greater dilution rate. However, some of the groundwater production estimates then became erratic due to these adjustments. In the future, LiBr tracer concentrations should again be adjusted as water flow dictates, but water production estimates determined from $\mathrm{LiBr}$ monitoring should also be confirmed with visual estimates and sump volume calculations.

- After discharge of excess groundwater to the ground surface was approved, water was allowed to flow from the sump discharge pipe. However, the high flow caused damage to the access road (no natural areas were affected), and crews had to be mobilized to repair the road bed. In the future, drainage issues should be considered in advance of any surface discharge so that proper diversions can be provided if necessary to prevent damage to roads and other surfaces.

- The primary geophysical contractor again encountered problems with malfunctioning tools and delays in obtaining a properly cleaned replacement tool. Future logging operations should require testing of each tool prior to arrival at the job site. 


\subsection{References}

Bechtel Nevada, 1999a. Western Pahute Mesa/Oasis Valley (WPM-OV) Investigation Wells SiteSpecific Health and Safety Plan (SSHASP). February 1999. Las Vegas, NV.

Bechtel Nevada, 1999b. Drilling Program for Underground Test Area (UGTA) Western Pahute Mesa/Oasis Valley (WPM-OV) Investigation Well ER-EC-8 - Original. Drilling Work Plan Number D-007-001.99. July 14, 1999. Las Vegas, NV.

Bechtel Nevada, 2002. A Hydrostratigraphic Model and Alternatives for the Groundwater Flow and Contaminant Transport Model of Corrective Action Units 101 and 102: Central and Western Pahute Mesa, Nye County, Nevada. DOE/NV/11718--706. Las Vegas, NV.

BN, see Bechtel Nevada.

DOE, see U.S. Department of Energy.

Fleck, R. J., B. D. Turrin, D. A. Sawyer, R. G. Warren, D. E. Champion, M. R. Hudson, and S. A. Minor, 1996. "Age and Character of Basaltic Rocks of the Yucca Mountain Region, Southern Nevada." Journal of Geophysical Research, v. 101, pp. 8,205-8,227.

Fridrich, C. J., S. A. Minor, and E. A. Mankinen, 1999a. Geologic Evaluation of the Oasis Valley Basin, Nye County, Nevada. U. S. Geological Survey Open-File Report 99-533-A. Denver, $\mathrm{CO}$.

Fridrich, C. J., S. A. Minor, P. L. Ryder, and J. L. Slate, 1999b. Geologic Map of the Oasis Valley Basin and Vicinity, Nye County, Nevada. U.S. Geological Survey Open-File Report 99-533-B. Denver, CO.

Grauch, V. J. S., D. A. Sawyer, C. J. Fridrich, and M. R. Hudson, 1997. Geophysical Interpretations West of and Within the Northwestern Part of the Nevada Test Site. U.S. Geological Survey Open-File Report 97-476. Denver, CO.

Hildenbrand, T. G., V. E. Langenheim, E. A. Mankinen, and E. H. McKee, 1999. Inversion of Gravity Data to Define the Pre-Tertiary Surface and Regional Structures Possibly Influencing Ground-Water Flow in the Pahute Mesa - Oasis Valley Region, Nye County, Nevada. U.S. Geological Survey Open-File Report 99-49. Menlo Park, CA.

IT, see IT Corporation.

IT Corporation, 1998. FY99 Western Pahute Mesa - Oasis Valley Hydrogeologic Investigation Wells Drilling and Completion Criteria, ITLV/13052-049. Prepared for DOE/NV. Las Vegas, NV. 
IT Corporation, 1999. Written communication prepared for DOE/NV. Subject: "Western Pahute Mesa - Oasis Valley ER-EC-8 Well Data Report.” September 1999. ITLV/13052--075. Las Vegas, NV.

Laczniak, R. J., J. C. Cole, D. A. Sawyer, and D. A. Trudeau, 1996. Summary of Hydrogeologic Controls on Ground Water Flow at the Nevada Test Site, Nye County, Nevada. U.S. Geological Survey Water Resources Investigations Report 96-4109.

Mankinen, E. A., T. G. Hildenbrand, G. L. Dixon, E. H. McKee, C. J. Fridrich, and R. J. Laczniak, 1999. Gravity and Magnetic Study of the Pahute Mesa and Oasis Valley Region, Nye County, Nevada, U.S. Geological Survey Open-File Report 99-303. Menlo Park, CA.

Sawyer, D. A., J. J. Fleck, M. A. Lanphere, R. G. Warren, and D. E. Broxton, 1994. "Episodic Caldera Volcanism in the Miocene Southwest Nevada Volcanic Field: Revised Stratigraphic Caldera Framework, ${ }^{40} \mathrm{Ar} /{ }^{39} \mathrm{Ar}$ Geochronology, and Implications for Magmatism and Extension." Geological Society of America Bulletin, v. 67, n. 10, pp. 1,304-1,318.

U.S. Department of Energy, 1996a. Attachment 1, "Fluid Management Plan for the Underground Test Area Subproject." In Underground Test Area Subproject Waste Management Plan, Revision 1, DOE/NV--343. Las Vegas, NV.

U.S. Department of Energy, 1996b. Underground Test Area Subproject Waste Management Plan, Rev. 1, DOE/NV--343. Las Vegas, NV.

U.S. Department of Energy, 1998. Nevada Environmental Restoration Project Health and Safety Plan, Revision 3, February 1998. Las Vegas, NV.

U.S. Department of Energy, 2003. Completion Report for Well ER-18-2. DOE/NV/11718--388. Las Vegas, NV.

U.S. Department of Energy, 2004. Completion Report for Well ER-EC-5. DOE/NV/11718--424. Las Vegas, NV.

Wahl, R. R., D. A. Sawyer, M. D. Carr, S. A. Minor, J. C. Cole, WC Swadley, R. J. Laczniak, R. G. Warren, K. S. Green, and C. M. Engle, 1997. Digital Geologic Map of the Nevada Test Site Area, Nevada. U.S. Geological Survey Open-File Report 97-140, scale, 1:120,000. Denver, $\mathrm{CO}$.

Warren, R.G., 1994. Written communication to Ed Price, GeoTrans, Las Vegas, NV. Subject: "Structural Elements and Hydrogeologic Units of the Southwestern Nevada Volcanic Field," Attachment to Los Alamos National Laboratory letter, May 1994. 19 pp., 4 figures, structural block model map, 2 cross sections. 
Warren, R. G., 2003. Written communication via E-mail to Lance Prothro, Bechtel Nevada, Las Vegas, NV, dated June 26, 2003. Subject: Analytical results for samples from Well ER-EC-8.

Warren, R. G., D. A. Sawyer, F. M. Byers, Jr., and G. L. Cole. 2003. "A Petrographic, Geochemical, and Geophysical Database and Stratigraphic Framework for the Southwestern Nevada Volcanic Field.” Los Alamos National Laboratory Report LA-UR-03-1503, 54 pp. 
This page intentionally left blank.

10-4 


\section{Appendix A \\ Drilling Data}

$\begin{array}{ll}\text { A-1 } & \text { Drilling Parameter Log for Well ER-EC-8 } \\ \text { A-2 } & \text { Casing Data for Well ER-EC-8 } \\ \text { A-3 } & \text { Well ER-EC-8 Drilling Fluids and Cement Composition }\end{array}$ 
Appendix A-1

Drilling Parameter Log for Well ER-EC-8 


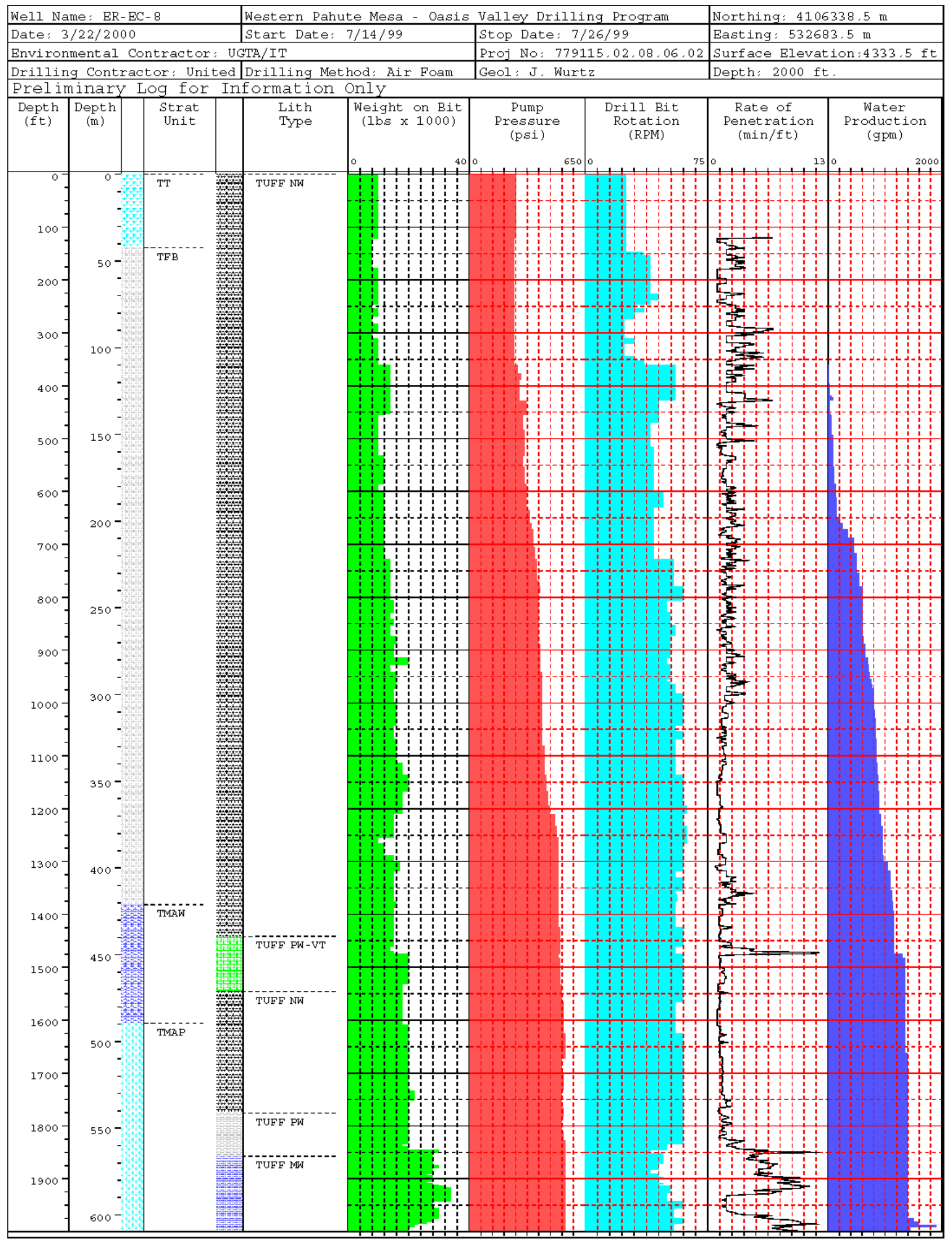


This page intentionally left blank.

A-1-2 
Appendix A-2

Casing Data for Well ER-EC-8 


\section{Casing Data for Well ER-EC-8}

\begin{tabular}{||c|c|c|c|c|c|c|c||}
\hline Casing & $\begin{array}{c}\text { Depth Interval } \\
\text { meters } \\
\text { (feet) }\end{array}$ & Type & Grade & $\begin{array}{c}\text { Outside } \\
\text { Diameter } \\
\text { centimeters } \\
\text { (inches) }\end{array}$ & $\begin{array}{c}\text { Inside } \\
\text { Diameter } \\
\text { centimeters } \\
\text { (inches) }\end{array}$ & $\begin{array}{c}\text { Wall } \\
\text { Thickness } \\
\text { centimeters } \\
\text { (inches) }\end{array}$ & $\begin{array}{c}\text { Weight } \\
\text { per foot } \\
\text { (pounds) }\end{array}$ \\
\hline $\begin{array}{c}\text { Conductor } \\
\text { Casing }\end{array}$ & $\begin{array}{c}0 \text { to } 36.7 \\
\text { (0 to } 120.5)\end{array}$ & $\begin{array}{c}\text { Carbon } \\
\text { Steel }\end{array}$ & $\mathrm{K} 55$ & $\begin{array}{c}50.80 \\
(20)\end{array}$ & $\begin{array}{c}48.575 \\
19.124\end{array}$ & $\begin{array}{c}1.113 \\
(0.438)\end{array}$ & 94 \\
\hline $\begin{array}{c}\text { Surface } \\
\text { Casing }\end{array}$ & $\begin{array}{c}0 \text { to } 129.8 \\
(0 \text { to } 426.0)\end{array}$ & $\begin{array}{c}\text { Carbon } \\
\text { Steel }\end{array}$ & $\mathrm{K} 5$ & $\begin{array}{c}33.97 \\
(13.375)\end{array}$ & $\begin{array}{c}32.042 \\
(12.615)\end{array}$ & $\begin{array}{c}0.965 \\
(0.380)\end{array}$ & 54.5 \\
\hline $\begin{array}{c}\text { Completion } \\
\text { Casing } \\
\text { (with cross- } \\
\text { over) }\end{array}$ & $\begin{array}{c}0 \text { to } 189.7 \\
(0 \text { to } 622.4)\end{array}$ & $\begin{array}{c}\text { Carbon } \\
\text { Steel with } \\
\text { internal } \\
\text { epoxy } \\
\text { coating }\end{array}$ & $\mathrm{N} 80$ & $\begin{array}{c}19.37 \\
(7.625)\end{array}$ & $\begin{array}{c}17.701 \\
(6.969)\end{array}$ & $\begin{array}{c}0.833 \\
(0.328)\end{array}$ & 26.4 \\
\hline $\begin{array}{c}\text { Completion } \\
\text { Casing }\end{array}$ & $\begin{array}{c}189.7 \text { to } 594.4 \\
(622.4 \text { to } 1,950.0)\end{array}$ & $\begin{array}{c}\text { Stainless } \\
\text { Steel }\end{array}$ & T304L & $\begin{array}{c}13.97 \\
(5.5)\end{array}$ & $\begin{array}{c}12.819 \\
(5.047)\end{array}$ & $\begin{array}{c}0.577 \\
(0.227)\end{array}$ & 14.6 \\
\hline
\end{tabular}


This page intentionally left blank.

A-2-2 
Appendix A-3

Well ER-EC-8 Drilling Fluids and Cement Composition 
Table A-3-1

\section{Well ER-EC-8 Drilling Fluids}

\begin{tabular}{|c||}
\hline Typical Air-Foam/Polymer Mix ${ }^{\mathrm{a}}$ \\
8 to 19 liters (2 to 5 gallons) Acrylafoam ${ }^{\circledR \mathrm{b}}$ \\
and \\
4 to 11 liters (1 to 3 gallons) Acrylavis ${ }^{\circledR \mathrm{b}}$ \\
per \\
7,949 liters (50 barrels) water \\
\hline
\end{tabular}

a

The conductor hole was dry-augered from the surface to a depth of 37.2 meters (122 feet). During air-foam drilling below 37.2 meters (122 feet), various proportions of polymer were added to suit conditions.

b $\quad$ Acrylafoam ${ }^{\circledR}$ foaming agent and Acrylavis ${ }^{\circledR}$ polymer additive are products of Enterprise Drilling Fluids, Inc.

\section{NOTES:}

1. All water used to mix drilling fluids for Well ER-EC-8 came from the Coffer Dune well located near the Coffer Homestead.

2. A concentrated solution of lithium bromide was added to all introduced fluids to make up a final concentration of 30 to 40 milligrams per liter.

Table A-3-2

Well ER-EC-8 Cement Composition

\begin{tabular}{|c|c|c|c|}
\hline Cement Composition & 20-inch Conductor Casing & 13d -inch Surface Casing & Completion \\
\hline $\begin{array}{c}\text { Type II plus } \\
25 \text { percent sand }\end{array}$ & $\begin{array}{l}0 \text { to } 37.2 \mathrm{~m}^{\mathrm{a}} \\
\left(0 \text { to } 122 \mathrm{ft}^{\mathrm{b}}\right)\end{array}$ & Not used & Not used \\
\hline Type II & $\begin{array}{l}0 \text { to } 11.0 \\
(0 \text { to } 36)\end{array}$ & $\begin{array}{l}\text { Above cement baskets } \\
0 \text { to } 15.2 \mathrm{~m} \\
(0 \text { to } 50 \mathrm{ft}) \\
73.2^{\mathrm{c}} \text { to } 130.5 \mathrm{~m} \\
\left(240^{\mathrm{C}} \text { to } 428 \mathrm{ft}\right)\end{array}$ & $\begin{array}{c}21.3 \text { to } 192.6 \mathrm{~m} \\
\text { (70 to } 632 \mathrm{ft}) \\
320.0 \text { to } 350.2 \mathrm{~m} \\
(1,050 \text { to } 1,149 \mathrm{ft}) \\
408.4 \text { to } 423.1 \mathrm{~m} \\
(1,340 \text { to } 1,388 \mathrm{ft}) \\
474.9 \text { to } 495.6 \mathrm{~m} \\
(1,558 \text { to } 1,626 \mathrm{ft})\end{array}$ \\
\hline
\end{tabular}
a $\operatorname{meter}(\mathrm{s})$
b foot (feet)
c estimated 
This page intentionally left blank.

A-3-2 
Appendix B

Well ER-EC-8 Fluid Management Data 


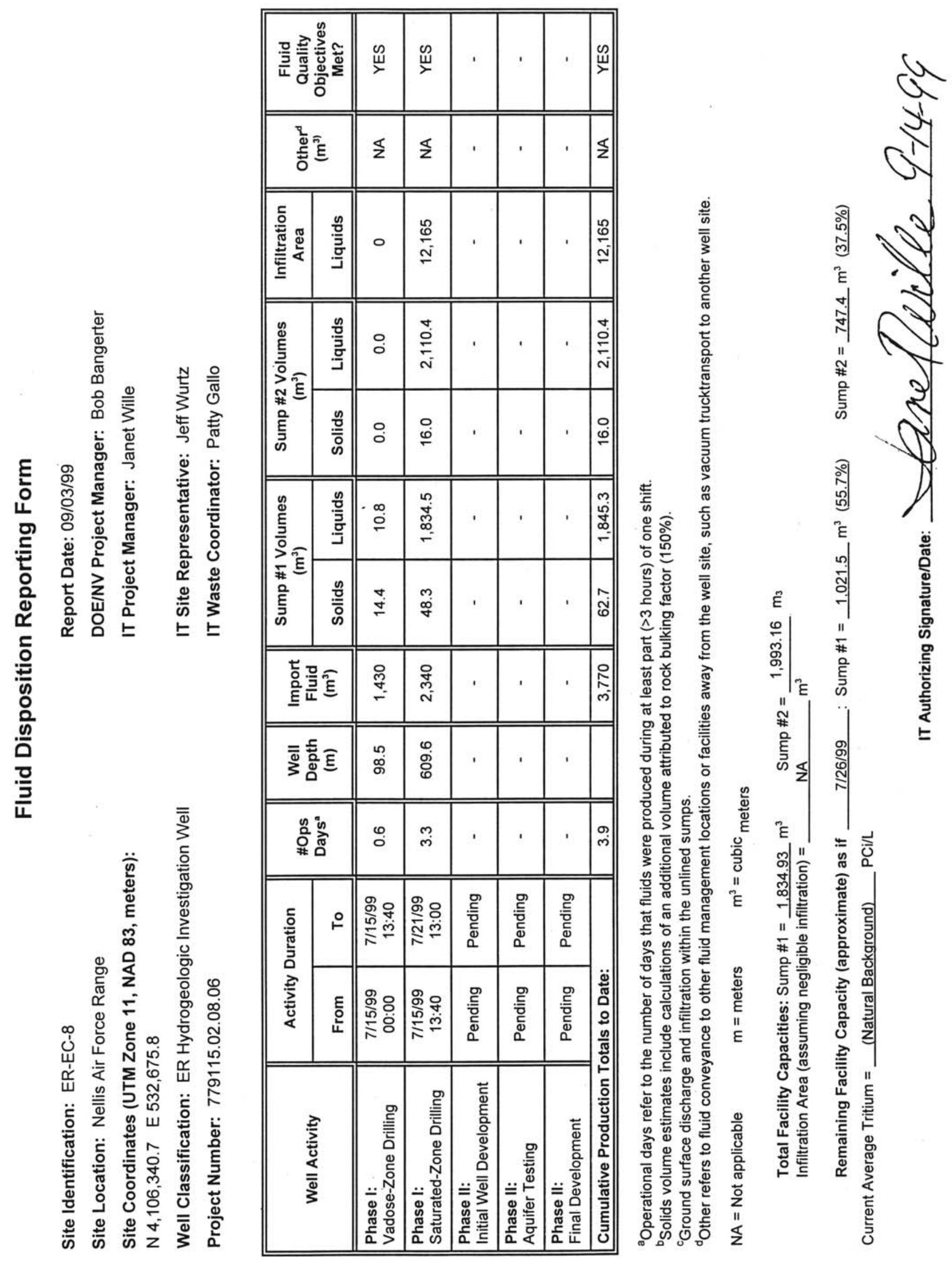


Preliminary Analytical Results for Fluid Management Samples: Well ER-EC-8

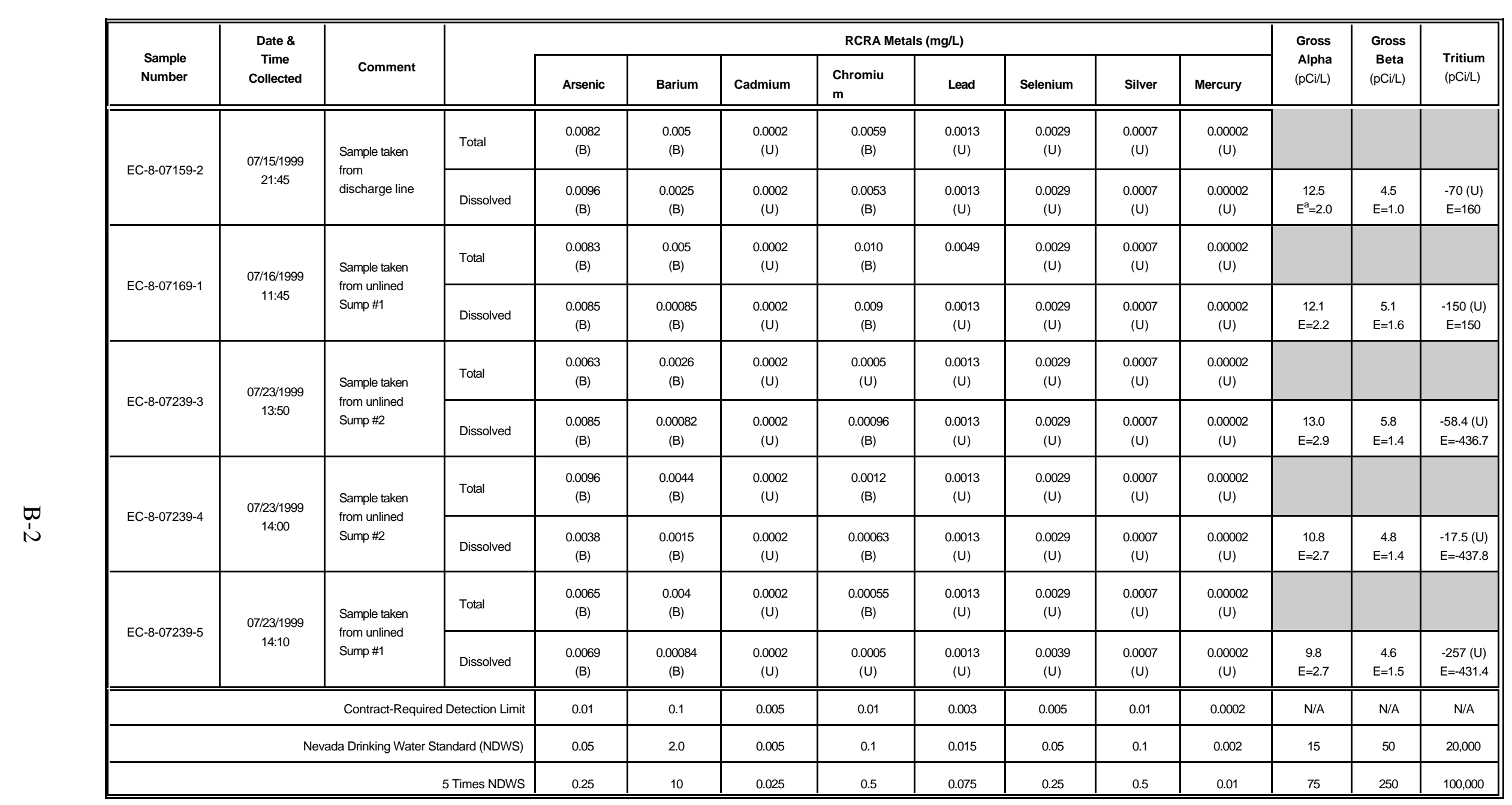

Analysis of metals by Paragon Analytics, Inc.; analysis of radionuclides by Bechtel Nevada

\section{a Error.}

RCRA = Resource Conservation and Recovery Act of 1976

$\mathrm{N} / \mathrm{A}=$ not applicable

$\mathrm{mg} / \mathrm{L}=$ milligrams per liter

$\mathrm{pCi} / \mathrm{L}=$ picocuries per liter

$\mathrm{B}=$ Result less than CRDL, but greater than the IDL

$U=$ Result less the IDL or the Minimum Detectable Concentration (MDC)

$\mathrm{CRDL}=$ Contract-Required Detection Limit

IDL = Instrument Detection Limit 


\section{Appendix C}

Detailed Lithologic Log for Well ER-EC-8 


\section{Detailed Lithologic Log for Well ER-EC-8}

Logged by Lance Prothro, Bechtel Nevada

\begin{tabular}{|c|c|c|c|c|c|}
\hline $\begin{array}{c}\text { Depth } \\
\text { Interval } \\
\text { meters (feet) }\end{array}$ & $\begin{array}{c}\text { Thickness } \\
\text { meters } \\
\text { (feet) }\end{array}$ & $\begin{array}{l}\text { Sample } \\
\text { Type a }^{\text {a }}\end{array}$ & $\begin{array}{l}\text { Laboratory } \\
\text { Analyses }\end{array}$ & Lithologic Description $^{c}$ & $\begin{array}{c}\text { Stratigraphic } \\
\text { Unit }\end{array}$ \\
\hline $\begin{array}{c}0-42.4 \\
(0-139)\end{array}$ & $\begin{array}{l}42.4 \\
(139)\end{array}$ & $\begin{array}{l}\text { DB1, } \\
\text { DB2 }\end{array}$ & None & $\begin{array}{l}\text { Nonwelded Tuff: Samples are a mixture of loose feldspar crystals } \\
\text { and fragments of nonwelded tuff and cement. Tuff fragments are } \\
\text { devitrified to zeolitic and peralkaline. } \\
\text { No samples above } 36.6 \mathrm{~m} \text { ( } 120 \mathrm{ft} \text { ). Stratigraphic and lithologic } \\
\text { assignments based partly on nearby surface geology. }\end{array}$ & $\begin{array}{l}\text { Thirsty } \\
\text { Canyon } \\
\text { Group, } \\
\text { undivided } \\
\text { (Tt) }\end{array}$ \\
\hline $\begin{array}{l}42.4-47.5 \\
(139-156)\end{array}$ & $\begin{array}{c}5.2 \\
(17)\end{array}$ & DA & $\begin{array}{c}\text { PTS, XRD, } \\
\text { XRF, } \\
\mathrm{Fe}^{2+} / \mathrm{Fe}^{3+}\end{array}$ & $\begin{array}{l}\text { Nonwelded Tuff: Grayish orange pink (5YR } 7 / 2) \text { and very pale } \\
\text { orange (10YR 8/2); zeolitic, lesser opaline alteration; abundant very- } \\
\text { pale-orange (10YR 8/2) pumice; minor felsic phenocrysts of feldspar } \\
\text { and quartz; abundant biotite; minor mostly dark-reddish-brown } \\
\text { (10R 3/4) lithic fragments. }\end{array}$ & \multirow{5}{*}{$\begin{array}{l}\text { Beatty Wash } \\
\text { Formation } \\
\text { (Tfb) }\end{array}$} \\
\hline $\begin{array}{l}47.5-54.9 \\
(156-180)\end{array}$ & $\begin{array}{l}7.3 \\
(24)\end{array}$ & DA & None & $\begin{array}{l}\text { Nonwelded Tuff: Moderate yellowish brown (10YR } 5 / 4) \text {; zeolitic and } \\
\text { silicic; minor very-pale-orange (10YR } 8 / 2) \text { pumice; common felsic } \\
\text { phenocrysts of quartz and feldspar; minor partially altered biotite; } \\
\text { minor lithic fragments. }\end{array}$ & \\
\hline $\begin{array}{l}54.9-73.2 \\
(180-240)\end{array}$ & $\begin{array}{l}18.3 \\
(60)\end{array}$ & DB1 & None & $\begin{array}{l}\text { Nonwelded Tuff: Moderate orange pink (10R } 7 / 4) \text {; argillic, lesser } \\
\text { zeolitic alteration; very pumiceous texture; minor to common feldspar } \\
\text { phenocrysts; minor to common biotite; sphene is present; rare lithic } \\
\text { fragments. }\end{array}$ & \\
\hline $\begin{array}{c}73.2-103.6 \\
(240-340)\end{array}$ & $\begin{array}{l}30.5 \\
(100)\end{array}$ & DA & $\begin{array}{c}\text { PTS, XRD, } \\
\text { XRF, } \\
\mathrm{Fe}^{2+} / \mathrm{Fe}^{3+}\end{array}$ & $\begin{array}{l}\text { Bedded Tuff: Pinkish gray (5YR 8/1) and yellowish gray (5Y } 8 / 1) \text {; } \\
\text { zeolitic and lesser silicic alteration; very pumiceous texture; minor } \\
\text { felsic phenocrysts of quartz and partially altered feldspar; abundant } \\
\text { partially altered biotite and pseudomorphs after biotite; trace of } \\
\text { hornblende; sphene is present; rare lithic fragments. }\end{array}$ & \\
\hline $\begin{array}{c}103.6-302.1 \\
(340-991)\end{array}$ & $\begin{array}{l}198.4 \\
(651)\end{array}$ & $\mathrm{DA}, \mathrm{SC}$ & $\begin{array}{l}\text { PTS, XRD, } \\
\text { XRF, } \\
\mathrm{Fe}^{2+} / \mathrm{Fe}^{3+}\end{array}$ & $\begin{array}{l}\text { Nonwelded Tuff: Yellowish gray ( } 5 Y 7 / 2) \text {; zeolitic, lesser silicic and } \\
\text { opaline; abundant moderate-yellow ( } 5 Y \text { Y/6) pumice; minor feldspar } \\
\text { phenocrysts; common mafic minerals of biotite and much less } \\
\text { hornblende; sphene is present; rare to minor lithic fragments. }\end{array}$ & \\
\hline
\end{tabular}




\begin{tabular}{|c|c|c|c|c|c|}
\hline $\begin{array}{c}\text { Depth } \\
\text { Interval } \\
\text { meters (feet) }\end{array}$ & $\begin{array}{c}\text { Thickness } \\
\text { meters } \\
\text { (feet) }\end{array}$ & $\begin{array}{l}\text { Sample } \\
\text { Type a }^{\text {a }}\end{array}$ & $\begin{array}{l}\text { Laboratory } \\
\text { Analyses }\end{array}$ & Lithologic Description $^{c}$ & $\begin{array}{c}\text { Stratigraphic } \\
\text { Unit }\end{array}$ \\
\hline $\begin{array}{l}302.1-350.5 \\
(991-1,150)\end{array}$ & $\begin{array}{l}48.5 \\
(159)\end{array}$ & $\mathrm{DA}, \mathrm{SC}$ & $\begin{array}{c}\text { PTS, XRD, } \\
\text { XRF, } \\
\mathrm{Fe}^{2+} / \mathrm{Fe}^{3+}\end{array}$ & $\begin{array}{l}\text { Nonwelded Tuff: Light brown (5YR 5/6); mostly zeolitic, lesser } \\
\text { silicic alteration; common moderate-yellow ( } 5 \text { Y } 7 / 6) \text { pumice; minor } \\
\text { felsic phenocrysts of feldspar and lesser quartz; minor biotite; } \\
\text { sphene is present; rare dark-reddish-brown (10R } 3 / 4) \text { lithic fragments. }\end{array}$ & \multirow{3}{*}{$\begin{array}{c}\text { Beatty Wash } \\
\text { Formation } \\
\text { (Tfb) }\end{array}$} \\
\hline $\begin{array}{c}350.5-394.4 \\
(1,150-1,294)\end{array}$ & $\begin{array}{l}43.9 \\
(144)\end{array}$ & $\mathrm{DA}, \mathrm{SC}$ & None & $\begin{array}{l}\text { Nonwelded Tuff: Light brown (5YR 6/4) and pale yellowish brown } \\
\text { (10YR 6/2); zeolitic, much less silicic alteration; common moderate- } \\
\text { yellow ( } 5 \text { Y } 7 / 6 \text { ) pumice; minor felsic phenocrysts of feldspar and } \\
\text { lesser quartz; minor biotite; sphene is present; minor dark-reddish- } \\
\text { brown (10R } 5 / 4 \text { ) lithic fragments. }\end{array}$ & \\
\hline $\begin{array}{c}394.4-421.2 \\
(1,294-1,382)\end{array}$ & $\begin{array}{l}26.8 \\
(88)\end{array}$ & DA & $\begin{array}{c}\text { PTS, XRD, } \\
\text { XRF, } \\
\mathrm{Fe}^{2+} / \mathrm{Fe}^{3+}\end{array}$ & $\begin{array}{l}\text { Bedded Tuff: Yellowish gray (5Y 7/2) and light brown (5YR 6/4); } \\
\text { mostly zeolitic, lesser silicic alteration; minor to common grayish- } \\
\text { yellow (5Y 8/4) pumice; minor to common felsic phenocrysts of } \\
\text { feldspar and lesser quartz; common biotite; sphene is present; minor } \\
\text { to very abundant moderate-brown (5YR 3/4) and dark-reddish-brown } \\
\text { (10R 3/4) lithic fragments. }\end{array}$ & \\
\hline $\begin{array}{c}421.2-439.5 \\
(1,382-1,442)\end{array}$ & $\begin{array}{l}18.3 \\
(60)\end{array}$ & $\mathrm{DA}, \mathrm{SC}$ & $\begin{array}{c}\text { PTS, XRD, } \\
\text { XRF, } \\
\mathrm{Fe}^{2+} / \mathrm{Fe}^{3+}\end{array}$ & $\begin{array}{l}\text { Nonwelded Ash-Flow Tuff: Moderate-yellowish-brown (10YR 5/4) in } \\
\text { upper portion of interval, becoming light brown ( } 5 \text { YR } 5 / 6 \text { ) lower; } \\
\text { zeolitic; minor moderate-reddish-orange (10R 6/6) pumice; minor } \\
\text { felsic phenocrysts of feldspar and much less quartz; very abundant } \\
\text { biotite; much less pale-green ( } 5 G \text { G/2) clinopyroxene; no sphene } \\
\text { observed; rare lithic fragments. }\end{array}$ & \multirow{2}{*}{$\begin{array}{l}\text { tuff of } \\
\text { Buttonhook } \\
\text { Wash } \\
\text { (Tmaw) }\end{array}$} \\
\hline $\begin{array}{c}439.5-448.7 \\
(1,442-1,472)\end{array}$ & $\begin{array}{l}9.1 \\
(30)\end{array}$ & DA & None & $\begin{array}{l}\text { Partially to Moderately Welded Ash-Flow Tuff: Moderate reddish } \\
\text { brown (10R 4/6) to dark reddish brown (10R } 3 / 4) \text {; mostly devitrified, } \\
\text { lesser silicic alteration; minor pumice; minor felsic phenocrysts of } \\
\text { feldspar and much less quartz; minor biotite; no sphene observed; } \\
\text { rare lithic fragments. }\end{array}$ & \\
\hline
\end{tabular}




\begin{tabular}{|c|c|c|c|c|c|}
\hline $\begin{array}{c}\text { Depth } \\
\text { Interval } \\
\text { meters (feet) }\end{array}$ & $\begin{array}{c}\text { Thickness } \\
\text { meters } \\
\text { (feet) }\end{array}$ & $\begin{array}{l}\text { Sample } \\
\text { Type a }^{\text {a }}\end{array}$ & $\begin{array}{l}\text { Laboratory } \\
\text { Analyses }\end{array}$ & Lithologic Description $^{c}$ & $\begin{array}{c}\text { Stratigraphic } \\
\text { Unit }\end{array}$ \\
\hline $\begin{array}{c}448.7-451.1 \\
(1,472-1,480)\end{array}$ & $\begin{array}{l}2.4 \\
(8)\end{array}$ & $\mathrm{DA}, \mathrm{SC}$ & None & $\begin{array}{l}\text { Vitrophyric Ash-Flow Tuff: Moderate brown (5YR 4/4); devitrified } \\
\text { and vitric; minor felsic phenocrysts of feldspar and quartz; minor to } \\
\text { common mafic minerals of biotite and partially altered clinopyroxene; } \\
\text { no sphene observed; rare lithic fragments. }\end{array}$ & \multirow{3}{*}{$\begin{array}{l}\text { tuff of } \\
\text { Buttonhook } \\
\text { Wash } \\
\text { (Tmaw) }\end{array}$} \\
\hline $\begin{array}{c}451.1-471.2 \\
(1,480-1,546)\end{array}$ & $\begin{array}{l}20.1 \\
(66)\end{array}$ & $\mathrm{DA}, \mathrm{SC}$ & $\begin{array}{c}\text { PTS, XRD, } \\
\text { XRF, } \\
\mathrm{Fe}^{2+} / \mathrm{Fe}^{3+}\end{array}$ & $\begin{array}{l}\text { Partially Welded Ash-Flow Tuff: Pale red ( } 5 \mathrm{R} 6 / 2) \text { in upper portion, } \\
\text { becoming moderate brown ( } 5 \mathrm{YR} 4 / 4) \text { lower; devitrified, with vapor- } \\
\text { phase mineralization; common pumice; minor felsic phenocrysts of } \\
\text { feldspar and conspicuous quartz; minor to common biotite; sphene is } \\
\text { present; rare lithic fragments. }\end{array}$ & \\
\hline $\begin{array}{c}471.2-489.5 \\
(1,546-1,606)\end{array}$ & $\begin{array}{l}18.3 \\
(60)\end{array}$ & DA & None & $\begin{array}{l}\text { Nonwelded Ash-Flow Tuff: Moderate yellowish brown (10YR 5/4); } \\
\text { quartzo-feldspathic with substantial zeolite; common pumice; } \\
\text { common felsic phenocrysts of feldspar, including chatoyant sanidine, } \\
\text { and quartz; minor biotite, some partially altered; sphene is present; } \\
\text { minor lithic fragments. }\end{array}$ & \\
\hline $\begin{array}{c}489.5-541.3 \\
(1,606-1,776)\end{array}$ & $\begin{array}{l}51.8 \\
(170)\end{array}$ & $\mathrm{DA}, \mathrm{SC}$ & $\begin{array}{c}\text { PTS, XRD, } \\
\text { XRF, } \\
\mathrm{Fe}^{2+} / \mathrm{Fe}^{3+}\end{array}$ & $\begin{array}{l}\text { Nonwelded Ash-Flow Tuff: Pale yellowish brown (10YR } 6 / 2) \text { to } \\
512.1 \mathrm{~m}(1,680 \mathrm{ft}), \text { becoming pale red ( } 10 \mathrm{R} 6 / 2) \text { below } 512.1 \mathrm{~m} \\
(1,680 \mathrm{ft}) ; \text { quartzo-feldspathic with substantial zeolite; common } \\
\text { pumice; common felsic phenocrysts of feldspar, including chatoyant } \\
\text { sanidine, and quartz; minor biotite, some partially altered; sphene is } \\
\text { present; minor lithic fragments. }\end{array}$ & \multirow{2}{*}{$\begin{array}{l}\text { mafic-poor } \\
\text { Ammonia } \\
\text { Tanks Tuff } \\
\text { (Tmap) }\end{array}$} \\
\hline $\begin{array}{c}541.3-566.3 \\
(1,776-1,858)\end{array}$ & $\begin{array}{l}25.0 \\
(82)\end{array}$ & $\mathrm{DA}, \mathrm{SC}$ & $\begin{array}{c}\text { PTS, XRD, } \\
\text { XRF, } \\
\mathrm{Fe}^{2+} / \mathrm{Fe}^{3+}\end{array}$ & $\begin{array}{l}\text { Partially Welded Ash-Flow Tuff: Light brownish gray (5YR } 6 / 1) \text {; } \\
\text { quartzo-feldspathic; common pumice; minor to common felsic } \\
\text { phenocrysts of feldspar and quartz, some feldspars partially altered } \\
\text { and have a porcelain appearance; minor to common bronze-colored } \\
\text { biotite and pseudomorphs after biotite; sphene is present; minor lithic } \\
\text { fragments. }\end{array}$ & \\
\hline
\end{tabular}




\begin{tabular}{|c|c|c|c|c|c|}
\hline $\begin{array}{c}\text { Depth } \\
\text { Interval } \\
\text { meters (feet) }\end{array}$ & $\begin{array}{c}\text { Thickness } \\
\text { meters } \\
\text { (feet) }\end{array}$ & $\begin{array}{l}\text { Sample } \\
\text { Type a }^{\text {a }}\end{array}$ & $\begin{array}{l}\text { Laboratory } \\
\text { Analyses }\end{array}$ & Lithologic Description ${ }^{c}$ & $\begin{array}{c}\text { Stratigraphic } \\
\text { Unit }\end{array}$ \\
\hline $\begin{array}{c}566.3-609.6 \\
(1,858-2,000) \\
\text { Total Depth }\end{array}$ & $\begin{array}{l}43.3 \\
(142)\end{array}$ & $\mathrm{DA}, \mathrm{SC}$ & $\begin{array}{c}\text { PTS, XRD, } \\
\text { XRF, } \\
\mathrm{Fe}^{2+} / \mathrm{Fe}^{3+}\end{array}$ & $\begin{array}{l}\text { Moderately Welded Ash-Flow Tuff: Moderate brown (5YR } 3 / 4) \text { to } \\
\text { pale brown (5YR 5/2); quartzo-feldspathic; common spherulitic } \\
\text { pumice; minor to common felsic phenocrysts of quartz and partially } \\
\text { altered feldspar; minor biotite, including partially altered and } \\
\text { pseudomorphs after biotite; sphene is present; minor lithic fragments. }\end{array}$ & $\begin{array}{l}\text { mafic-poor } \\
\text { Ammonia } \\
\text { Tanks Tuff } \\
\text { (Tmap) }\end{array}$ \\
\hline
\end{tabular}

a $\quad$ DA $=$ drill cuttings that represent lithologic character of interval; $\mathbf{D B 1}=$ drill cuttings enriched in hard components; $\mathbf{D B 2}=$ drill cuttings from interval different than that drilled; $\mathbf{S C}=$ sidewall core.

b $\quad$ PTS $=$ polished thin section; $\mathbf{X R D}=\mathrm{X}$-ray diffraction; $\mathbf{X R F}=\mathrm{X}$-ray fluorescence $; \mathrm{Fe}^{2+} / \mathrm{Fe}^{3+}=$ wet chemical analysis for iron. See Table 3-2 of this report for additional information.

c Descriptions are based on visual examination of lithologic samples using a 10x-to 40x-zoom binocular microscope, and on geophysical logs. Colors describe wet sample color.

Abundances for felsic phenocrysts, pumice fragments, and lithic fragments: trace $=$ only one or two individuals observed; rare $=\leq 1 \%$; minor $=5 \%$; common $=10 \%$; abundant $=15 \%$; very abundant $=\geq 20 \%$

Abundances for mafic minerals: trace $=$ only one or two individuals observed; rare $=\leq 0.05 \%$; minor $=0.2 \%$; common $=0.5 \%$; abundant $=1 \%$; very abundant $=\geq 2 \%$ 
Appendix D

Geophysical Logs Run in Well ER-EC-8 
Appendix D contains unprocessed data presentations of selected geophysical logs run in

Well ER-EC-8. Table D-1 summarizes the logs presented. See Table 3-3 for more information.

Table D-1

Well ER-EC-8 Geophysical Logs Presented

\begin{tabular}{|c|c|c|c|c|}
\hline Log Type & $\begin{array}{l}\text { Run } \\
\text { Number }\end{array}$ & Date & \multicolumn{2}{|c|}{\begin{tabular}{cr}
\multicolumn{2}{c}{ Log Interval Presented } \\
meters
\end{tabular}} \\
\hline Epithermal Neutron & ENP-1 & $07 / 22 / 1999$ & $98.5-606.6$ & $323-1,990$ \\
\hline Density & CDL-1 & $07 / 22 / 1999$ & $98.5-606.6$ & $323-1,990$ \\
\hline $\begin{array}{l}\text { Dual Laterolog } \\
\text { (resistivity) }\end{array}$ & DLL-1 & $07 / 22 / 1999$ & $129.5-605.6$ & $425-1,987$ \\
\hline Spontaneous Potential & SP-1 & 07/22/1999 & $129.5-605.6$ & $425-1,987$ \\
\hline Gamma Ray & GR-1 & $07 / 22 / 1999$ & $121.9-608.1$ & $400-1,995$ \\
\hline $\begin{array}{l}\text { Digital Array Sonic } \\
\text { (delta T and sonic porosity) }\end{array}$ & $A C-1$ & $07 / 22 / 1999$ & $100.6-601.7$ & $330-1,974$ \\
\hline $\begin{array}{c}\text { Spectral Gamma Ray } \\
\text { (potassium, thorium, uranium) }\end{array}$ & SGR-1 & $07 / 22 / 1999$ & $0-597.7$ & $0-1,961$ \\
\hline Thermal Flow & 1 & 07/22/1999 & $176.8-512.1$ & $580-1,680$ \\
\hline $\begin{array}{c}\text { Chemistry } \\
\text { (temperature, } \mathrm{pH}, \text { electrical conductivity) }\end{array}$ & 1 & $07 / 22 / 1999$ & $100.3-606.6$ & $329-1,990$ \\
\hline
\end{tabular}




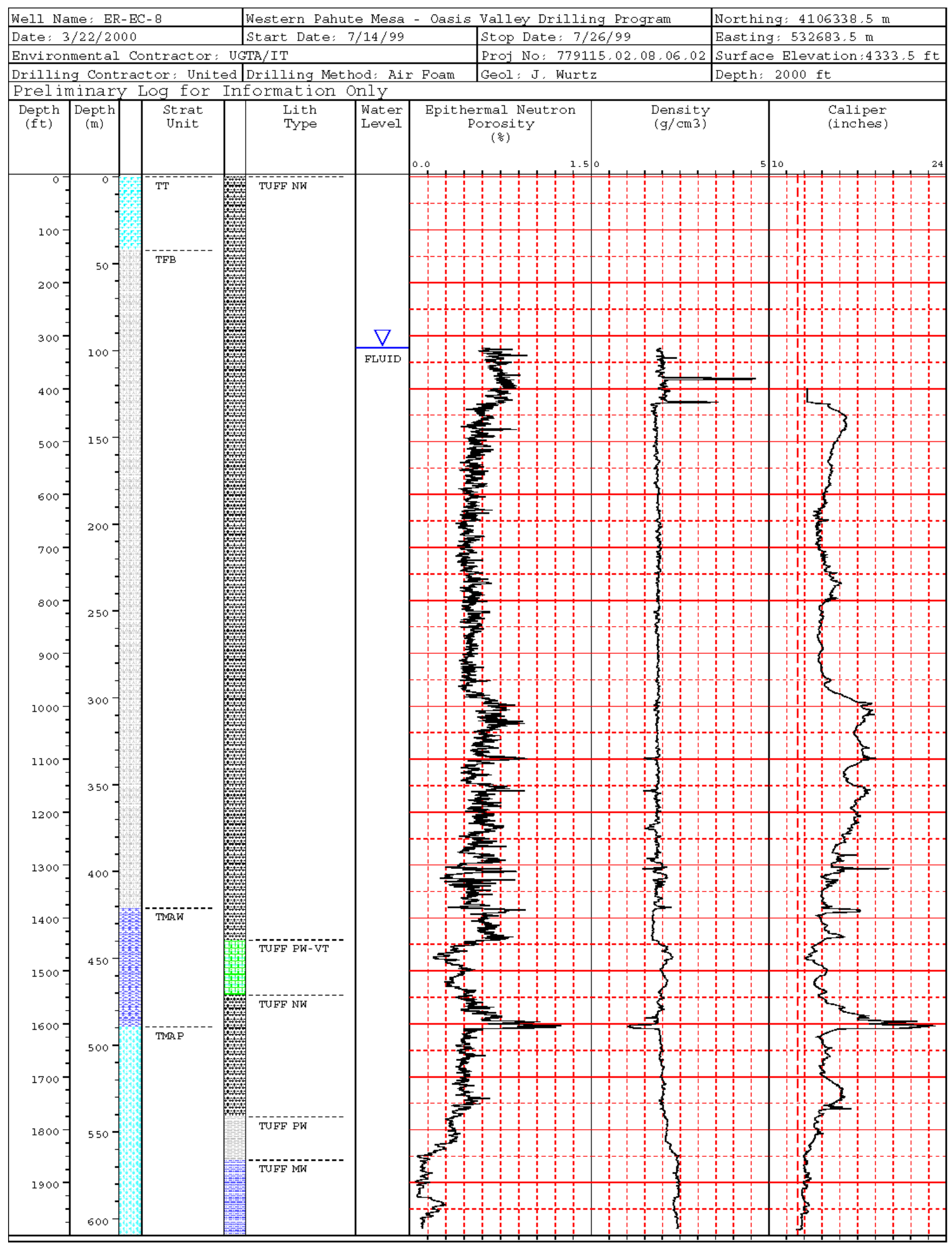




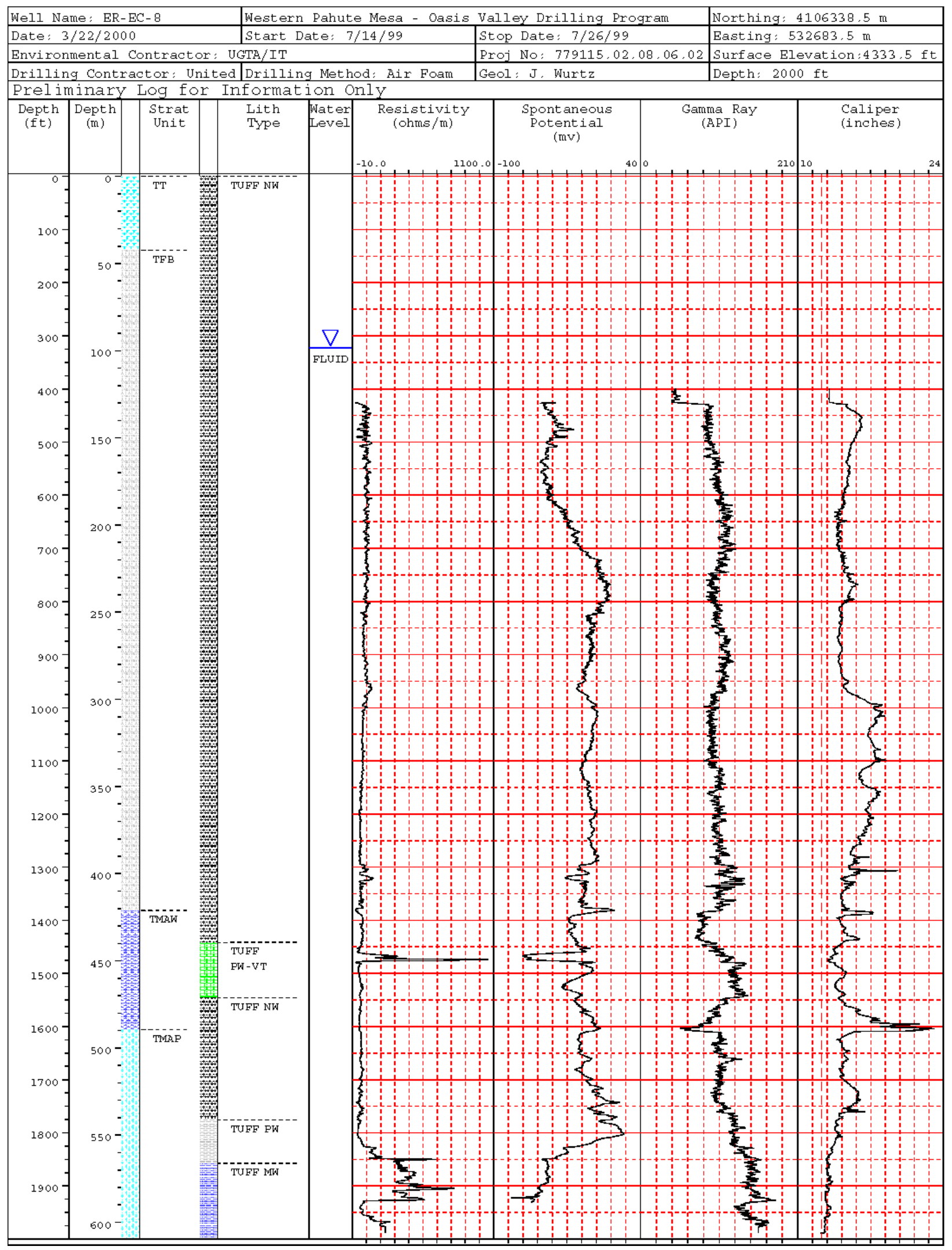




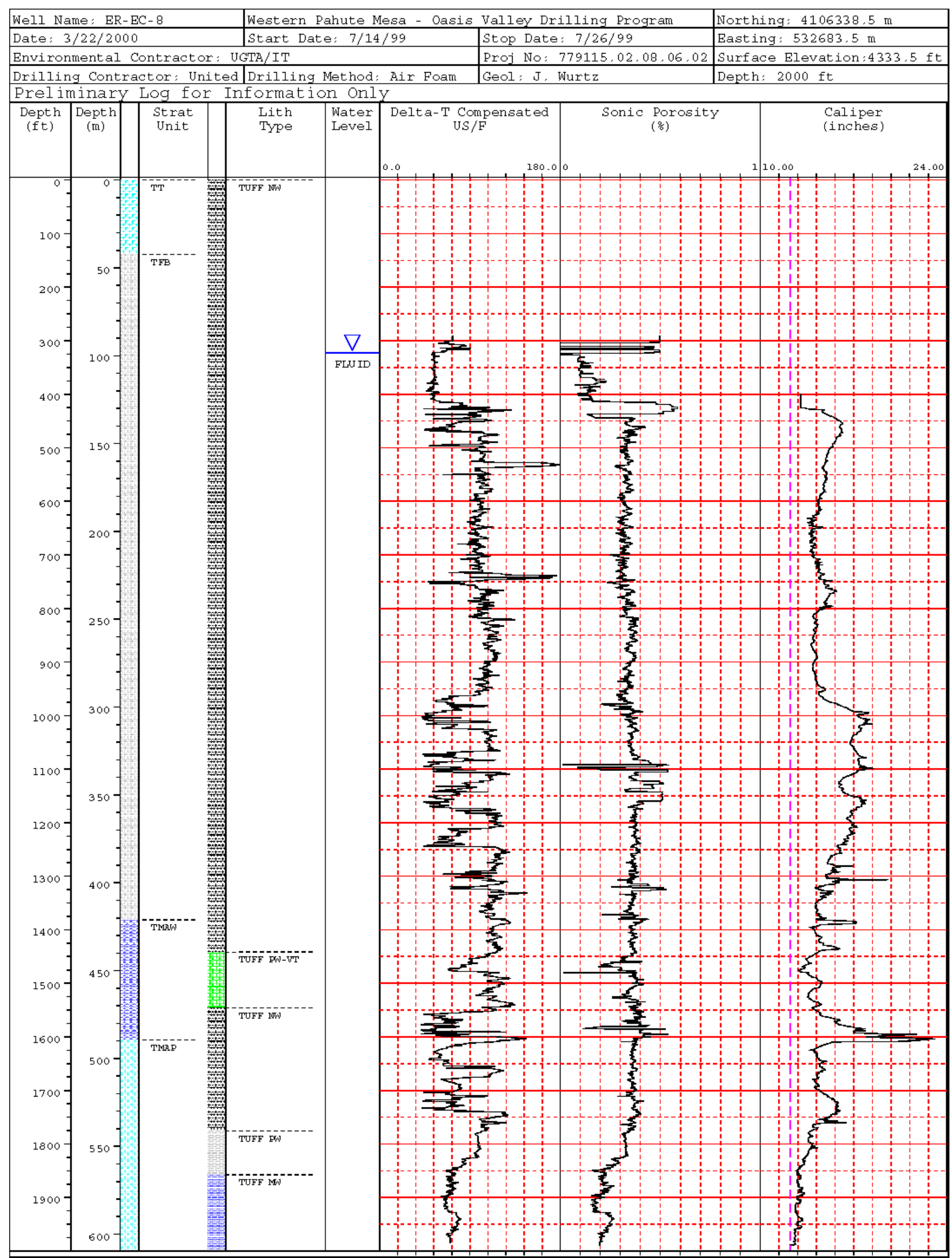




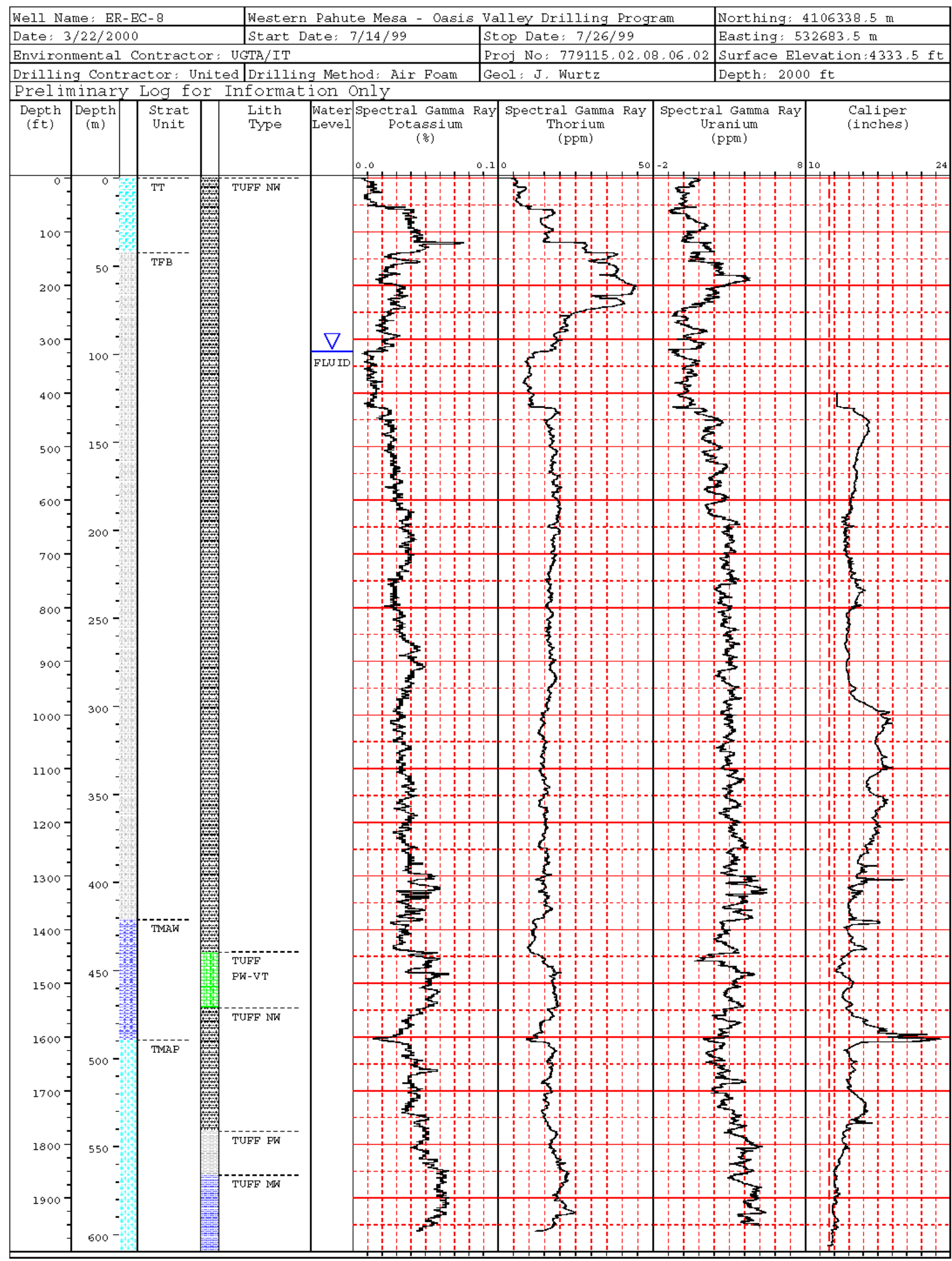




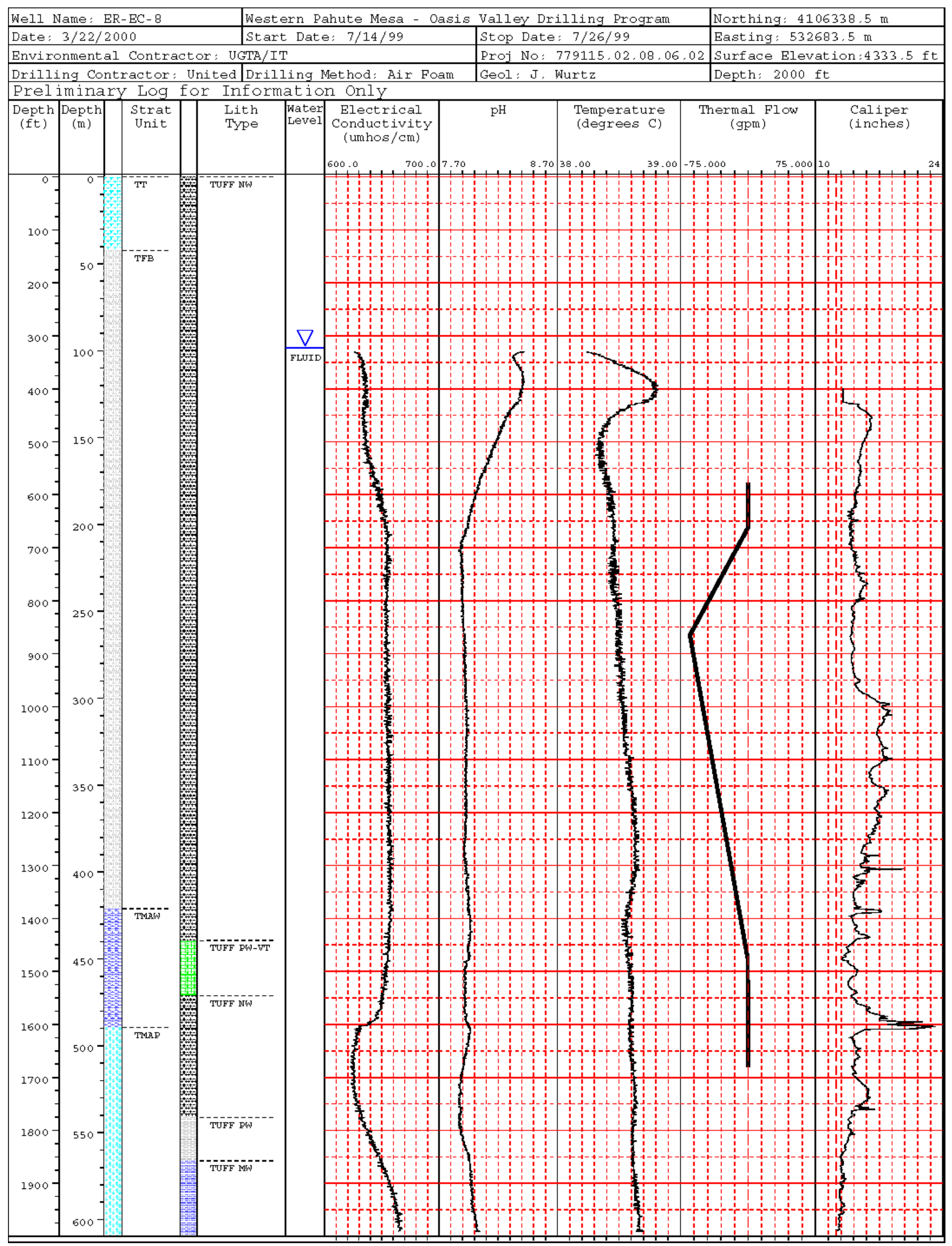




\section{Distribution List}

$\underline{\text { Copies }}$

R. M. Bangerter

U.S. Department of Energy

National Nuclear Security Administration

Nevada Site Office

Environmental Restoration Division

P.O. Box 98518, M/S 505

Las Vegas, NV 89193-8518

U.S. Department of Energy

National Nuclear Security Administration

Nevada Site Office

Technical Library

P.O. Box 98518, M/S 505

Las Vegas, NV 89193-8518

U.S. Department of Energy

National Nuclear Security Administration

Nevada Site Office

Public Reading Facility

P.O. Box 98518, M/S 505

Las Vegas, NV 89193-8518

U.S. Department of Energy

1 (electronic)

Office of Scientific and Technical Information

Post Office Box 62

Oak Ridge, Tennessee 37831-0062

K. A. Hoar, Director

U.S. Department of Energy

National Nuclear Security Administration

Nevada Site Office

Environment, Safety and Health Division

P.O. Box 98518, M/S 505

Las Vegas, NV 89193-8518

P. K. Ortego

Bechtel Nevada

P.O. Box 98521, MS NLV082

Las Vegas, NV 89193-8521 


\section{Distribution List (continued)}

\section{$\underline{\text { Copies }}$}

John McCord

UGTA Project Manager

Stoller-Navarro

7710 West Cheyenne Av.

Building 3

Las Vegas, NV 89129

Stoller-Navarro Library

Stoller-Navarro

7710 West Cheyenne Av.

Building 3

Las Vegas, NV 89129

W. L. Hawkins

Los Alamos National Laboratory

P. O. Box 1663

Los Alamos, NM 87545-1663

G. A. Pawloski

Lawrence Livermore National Laboratory

P. O. Box 808

Livermore, CA 94551-0808

T. P. Rose

Lawrence Livermore National Laboratory

P. O. Box 808

Livermore, CA 94551-0808

B. K. Thompson

DOE/USGS Cooperative Program Manager

U.S. Geological Survey

Water Resources Division

6770 South Paradise Road

Las Vegas, NV 89119-3721

C. E. Russell

Desert Research Institute

755 East Flamingo Road

P.O. Box 19040

Las Vegas, NV 89119-7363 